\title{
An Account of the Herring Investigations Conducted at Plymouth during the Years from 1924 to 1933.
}

By

E. Ford, A.R.C.Sc.,

Fisheries Naturalist at the Plymouth Laboratory.

With a Chart and 10 Figures in the Text.

\section{CONTENTS.}

INTRODUCTION

PAGE 306

The Plymouth Winter Drift-net Fishery . . . . . . . . . 308

Quantity and Value of Fish Landed . . . . . . . . . . . 309

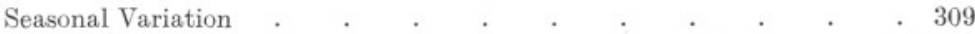

Daily Variation . . . . . . . . . . . . . . 310

The Intensity of Fishing . . . . . . . . . . . . . . 311

Changes in Fishing Power . . . . . . . . . . . . . . . 311

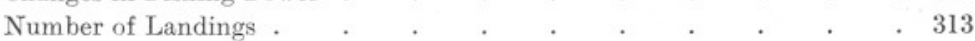

Size of Catches . . . . . . . . . . . . . . . . . . . 314

Seasonal Results . . . . . . . . . . . . . . . . . . . . . 315

The Drift-net as a Snare . . . . . . . . . . 315

The Effect of Gales . . . . . . . . . . . . . . . . 316

Inshore Fishing in Bigbury Bay . . . . . . . . . . $\quad . \quad 320$

Ray-Netting and Trawling in Bigbury Bay . . . . . . . $\quad . \quad 320$

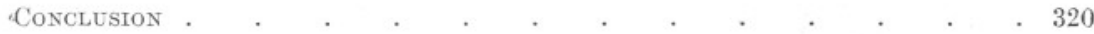

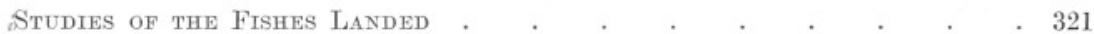

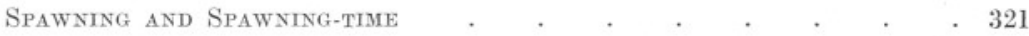

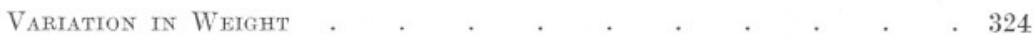

The Age of Fishes Landed . . . . . . . . . . . . . . 324

Length in Relation to Age . . . . . . . . . . . . . 326

Length $\left(\mathrm{l}_{1}\right)$ at Formation of First Winter Ring . . . . . . 327

Length $\left(\mathrm{l}_{2}\right)$ at Formation of Second Winter Ring . . . . . . 328

Correlation between the values of $\mathrm{l}_{1}$ and $\mathrm{l}_{2}$. . . . . . . . . 328

"Compensatory Growth" . . . . . . . . . . . . . 328

Growth in Length in different Geographical Areas . . . 333

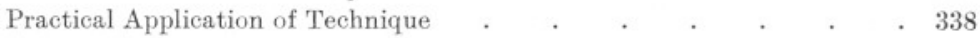

"Mixed" Growth . . . . . . . . . . . . 338

Growth in Length as Evidence of Migration . . . . . . . . 341

The Plymouth Shoals . . . . . . . . . . 342

NEW SERIES.-VOL. XIX. No. 1. AUGUST, 1933 . U 
Genotypes in the Herring

Variation in the Number of Vertebræ from Sample to Sample . $\quad 346$

The Conception of "Races" of Herrings . . . . . . . 350

The "Channel Sea Herring " and the "Smalls Herring" . . . 351

Samples from Plymouth and District . . . . . . . . . 357

Vertebral Variation among Spawning Fishes $\quad . \quad$. $\quad . \quad$. $\quad . \quad 359$

Herrings of the " $\mathrm{O}$ " Group . . . . . . . . . . . 363

The Sample and the Race . . . . . . . . . . . . 364

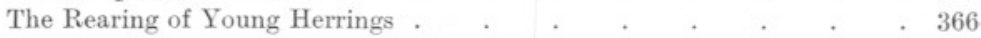

The Number of Myomeres in Larval Herrings . . . . . . 367

Incubation of Herring Eggs in Waters of different Salinities . . . $\quad 367$

The Metamorphosis of the Herring . . . . . . . 368

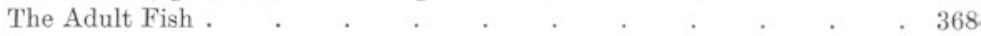

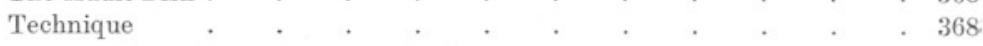

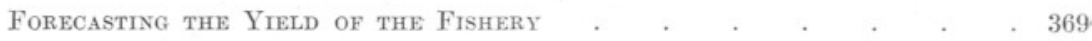

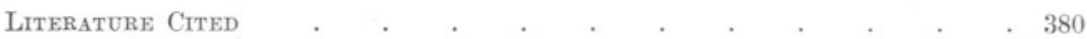

\section{INTRODUCTION.}

The Plymouth Laboratory is well situated for the study of the herring: and its commercial fishery, and since the winter of 1924-25, advantage has been taken of the varied facilities for research thus afforded. From time to time reports have been published in the Journal of the Marine Biological Association as a series, entitled: "Herring Investigations at Plymouth " and these have dealt with many seemingly distinct subjects of study, including experiments with larvæ from laboratory-fertilised eggs ; studies of growth, migration and structure of young and old fish ; and accounts of the commercial operations during the winter drift-fishery at Plymouth. It has now been considered advisable to bring together the several results in one paper, in an endeavour to show their essential bearing upon the problems of the practical fishery.

The first part of the paper is a descriptive account of the actual winter fishery at Plymouth which is of sufficient commercial importance to warrant the collection of information on the essentially business matters. of catching, landing and marketing. This fishery, however, no less than any other drift-net fishery, is perforce conducted under difficult conditions. of uncertainty. Fishermen and merchants alike are only too well aware of the extent to which the yield is liable to fluctuate from day to day and from season to season, and their business operations are rendered even more difficult because they can neither foresee nor prepare for the circumstances, favourable or otherwise, which each new season holds in store. It will not be questioned, therefore, that if scientific enquiry can ultimately succeed in removing this uncertainty from the fishery, it will have accomplished an essentially practical service. But it may be stated with equal assurance that this practical end can only be attained through a very exhaustive study of the life-history, habits and migration of the 


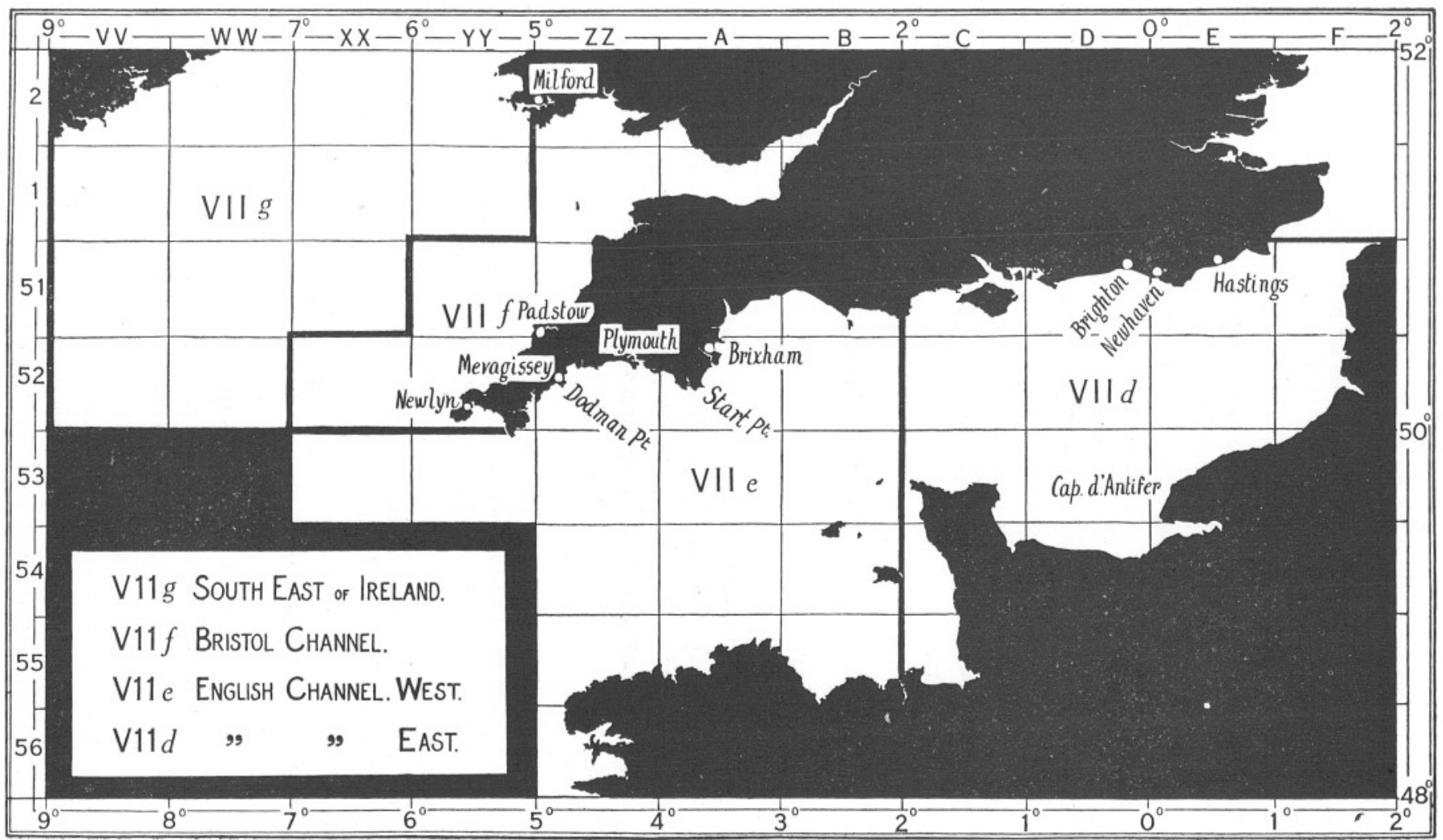


herring itself. And in this study the task of the investigator is made hard because so much of the needed information has to be sought for in an indirect way. The development of this indirect technique involves a great deal of preliminary research which at first sight appears to have but little bearing upon the practical fishery, but it is none the less essential. In the pages which follow, much of the text is devoted to the nature and application of such basic investigation, and an endeavour has been made to show how the different lines of enquiry meet in the central study of the fluctuations of the fishery. With so many distinct topics to be considered, it has not been found easy to preserve full continuity from section to section, although this has been done as far as possible. For the same reason it has been found impossible to avoid technical treatment in some instances, so that the general reader may find certain sections less easy to read than others. The paper concludes with a consideration of the question of forecasting the yield of the fishery from information gathered in preceding years.

\section{THE PLYMOUTH WINTER DRIFT-NET FISHERY.}

From November until the end of January, Sutton Harbour at Plymouth functions as the base for a large number of drifters which fish the neighbouring inshore waters for herrings. The season opens with the arrival of motor drifters from Cornish ports, but as soon as daily results prove sufficiently attractive (usually at the beginning of December) steamers from Lowestoft and Yarmouth augment the fleet. At the height of the season there may be between two and three hundred drifters at work. Circumstances permitting, they fish each night and land their catches in the morning. The steamers work continuously throughout the seven days of the week, but the Cornishmen do not land on Sundays.

Sutton Harbour and the adjoining fishmarket are the property of the Sutton Harbour Improvement Company, whose officers control the movèment of vessels to and from the fish quay and supervise market proceedings. Catches are sold by public auction on the evidence of small samples exposed on a tray in front of the auctioneer's rostrum. Fishermen bring their samples and queue up in front of the rostrum awaiting their turn for a sale.

The herrings are bought chiefly to supply a fresh-fish market either at home or abroad. Home buyers arrange to have their barrels and boxes stacked alongside the quay, so that purchases can be swung out of the ship in quarter-cran baskets and shot direct into the containers in which they are to be forwarded to their destination. The quantity taken out of the ship is checked basket by basket, and ice is strewn over the fish as packing proceeds. When packed and labelled, the consignment is conveyed by 
lorry to the railhead at one of the Plymouth stations. Herrings bought by the "Klondyke" trade for export to the Continent are not unloaded at the quayside but conveyed direct to the carrier-vessel by the drifters themselves.

\section{Quantity and Value of Fish Landed.}

The quantity and value of the fish landed at Plymouth vary from season to season and from day to day. The extent of these variations is considered below.

\section{Seasonal Variation.}

The Ministry of Agriculture and Fisheries collects statistics of the landings at Plymouth, and Table I shows the weight, value and average price of herrings landed during the months of December and January in the course of the past quarter of a century :-

\section{TABLE I.}

\begin{tabular}{|c|c|c|c|c|c|}
\hline $\begin{array}{c}\text { Season } \\
\text { (Dec.-Jan.) }\end{array}$ & $\begin{array}{l}\text { Total Weight } \\
\text { Landed. } \\
\text { Cwt. }\end{array}$ & $\begin{array}{c}\text { Total Value. } \\
£\end{array}$ & & $\begin{array}{l}\text { verage } \\
\text { per } 1 \\
\text { s. }\end{array}$ & $\begin{array}{l}\text { Price } \\
\text { Cwt. } \\
\text { d. }\end{array}$ \\
\hline $1906-07$ & 32,913 & 8,040 & & & 11 \\
\hline $1907-08$ & 23,957 & 6,583 & & 5 & 6 \\
\hline 1908-09 & 4,257 & 2,521 & & 111 & 10 \\
\hline $1909-10$ & 52,544 & 16,105 & & 6 & 1 \\
\hline $1910-11$ & 37,741 & 17,048 & & 9 & 0 \\
\hline $1911-12$ & 39,167 & 18,158 & & 9 & 3 \\
\hline $1912-13$ & 8,171 & 3,594 & & & 10 \\
\hline $1913-14$ & 28,886 & 13,933 & & 9 & 8 \\
\hline 1914-15 & 7,585 & 6,021 & & 15 & 11 \\
\hline $1915-16$ & 11,582 & 13,062 & & 22 & 7 \\
\hline $1916-17$ & 24,293 & 35,901 & $\begin{array}{l}\text { War } \\
\text { Period }\end{array}$ & 29 & 6 \\
\hline $1917-18$ & 38,108 & 88,453 & & 46 & 5 \\
\hline 1918-19 & 8,624 & 15,160 & & 35 & 2 \\
\hline $1919-20$ & 29,425 & 40,045 & & 27 & 3 \\
\hline $1920-21$ & 40,263 & 42,752 & & 21 & 3 \\
\hline $1921-22$ & 16,922 & 14,792 & & 17 & 6 \\
\hline $1922-23$ & 54,839 & 26,326 & & 9 & 8 \\
\hline $1923-24$ & 98,684 & 65,290 & & 13 & 3 \\
\hline $1924-25$ & 113,585 & 109,294 & & 19 & 3 \\
\hline $1925-26$ & 105,643 & 89,334 & & 16 & 11 \\
\hline $1926-27$ & 63,138 & 47,539 & & 15 & 1 \\
\hline $1927-28$ & 122,419 & 65,451 & & 10 & 8 \\
\hline $1928-29$ & 75,104 & 44,475 & & 11 & 10 \\
\hline $1929-30$ & 86,955 & 63,569 & & 14 & 7 \\
\hline $1930-31$ & 94,811 & 52,973 & & 11 & 2 \\
\hline $1931-32$ & $45,865+40$ by trawl & $37,620^{*}$ & & 16 & 5 \\
\hline $1932-33$ & $79,532+499$ by trawl & $41,025^{*}$ & & 10 & 3 \\
\hline
\end{tabular}

The figures show that the yield varies considerably from season to season. Even so, greater quantities have been landed since the war than before it, and the seasonal average price is still above that of 1913-14.

* Value inclusive of trawled fish. 


\section{Daily Variation.}

Information concerning daily variation in yield is obtainable from the daily returns of which the seasonal statistics given in Table I are the aggregate. It is found that there are many days in each season when the total weight of fish landed is comparatively small. For example, Table II is an analysis of daily statistics for the past five seasons :-

\section{TABLE II.}

No. of days on which landings were of the following weights (cwt.)

\begin{tabular}{|c|c|c|c|c|c|c|c|c|c|c|c|c|}
\hline $\begin{array}{c}\text { Season } \\
\text { (Dec. } \\
\text { Jan.) }\end{array}$ & $\begin{array}{l}\text { Total } \\
\text { No. of } \\
\text { Days. }\end{array}$ & $\begin{array}{l}\text { Less } \\
\text { than } \\
1000\end{array}$ & $\begin{array}{l}1000 \\
\text { to } \\
1999\end{array}$ & $\begin{array}{c}2000 \\
\text { to } \\
2999\end{array}$ & $\begin{array}{c}3000 \\
\text { to } \\
3999\end{array}$ & $\begin{array}{c}4000 \\
\text { to } \\
4999\end{array}$ & $\begin{array}{c}5000 \\
\text { to } \\
5999\end{array}$ & $\begin{array}{c}6000 \\
\text { to } \\
6999\end{array}$ & $\begin{array}{c}7000 \\
\text { to } \\
7999\end{array}$ & $\begin{array}{c}8000 \\
\text { to } \\
8999\end{array}$ & $\begin{array}{c}10000 \\
\text { to } \\
10999\end{array}$ & $\begin{array}{c}13000 \\
\text { to } \\
13999\end{array}$ \\
\hline $1928-\varepsilon 9$ & 54 & 35 & 6 & 4 & 3 & 3 & - & 1 & 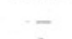 & 2 & - & - \\
\hline $1929-30$ & 54 & 30 & 15 & 3 & - & - & 2 & - & 1 & 1 & 1 & 1 \\
\hline $1930-31$ & 60 & 31 & 10 & 6 & 6 & 4 & 3 & - & - & - & - & - \\
\hline $1931-32$ & 60 & 44 & 11 & 2 & 1 & 2 & - & - & - & - & - & - \\
\hline $1932-33$ & 56 & 33 & 11 & 2 & 5 & 2 & 1 & - & 1 & - & 1 & - \\
\hline
\end{tabular}

It is seen that on considerably more than half the total number of days when landings were made, the amount landed was less than 1,000 cwt. Indeed, further analysis of statistics shows that the daily weight was actually less than 500 cwt. on $26,21,22,34$ and 26 days respectively, during the five seasons. This being so, it is hardly surprising that the comparatively occasional large daily landings should tend to sell at glut prices. The figures for 1929-30 provide a good illustration. During December and January, a total of 86,955 cwt. was landed. Of this amount, 36,502 cwt. was landed in 48 daily lots of less than 3,000 cwt., and sold for $£ 41,351$. This represents an average price of $22 \mathrm{~s}$. $8 \mathrm{~d}$. per 1 cwt. for approximately 42 per cent of the season's total catch. The remaining 58 per cent., or 50,453 cwt., was landed in 6 lots only and realised $£ 22,218$, representing an average price of $8 \mathrm{~s}$. 10d. Of these 6 lots, 3 were on the consecutive days, December 17th, 18th and 19th, when a total of no less than 30,900 cwt. was landed and sold at an average price of $6 \mathrm{~s} .4 \mathrm{~d}$.

A second illustration is provided by the statistics for the period, December 10th to 16 th, 1928 :-

\begin{tabular}{ccccc} 
Date. & Weight & Total & \multicolumn{2}{c}{ Price per } \\
1928. & Landed. & $£$ & \multicolumn{2}{c}{ 1 Cwt. } \\
Dee. & Cwt. & 564 & 50 & 10 \\
10 & 222 & 10 & 28 & 7 \\
11 & 7 & 1,465 & 20 & 0 \\
12 & 1,465 & 4,600 & 11 & 5 \\
13 & 8,050 & 2,926 & 7 & 3 \\
14 & 8,050 & 1,785 & 5 & 11 \\
15 & 6,030 & 1,525 & 710 \\
16 & 3,875 & &
\end{tabular}

From these two illustrations it is clear that only limited significance can be attached to the seasonable average price per 1 cwt., obtained by 
dividing the total value for the season by the total weight sold. This average tends to mask the relation which exists between the weight of fish landed in any one day and the price which it commands.

\section{The Intensity of Fishing.}

One of the causes of fluctuation in yield is that the intensity of fishing varies. The number of fishing vessels which participate in the fishery is not constant from season to season, and conditions of weather often seriously curtail the activities of those which do come. These and other factors affecting the intensity of fishing will now be considered.

\section{Changes in Fishing Power.}

The composition of the fishing fleet in each season since 1918-19 is shown in Table III, the data being supplied by Mr. W. G. Nelder, Manager of the Sutton Harbour Improvement Company, Plymouth :-

TABLE III.

\begin{tabular}{|c|c|c|c|}
\hline & $\begin{array}{l}\text { Number of } \\
\text { East Country }\end{array}$ & $\begin{array}{l}\text { Number of } \\
\text { West Country (Cornish) }\end{array}$ & $\begin{array}{l}\text { Number of } \\
\text { Local }\end{array}$ \\
\hline Season. & Steamers. & Motor Drifters. & Motor Drifters. \\
\hline $1918-19$ & 33 & 139 & $\uparrow$ \\
\hline $1919-20$ & 30 & 156 & \\
\hline $1920-21$ & 26 & 182 & Average No. is 10 , \\
\hline $1921-22$ & 31 & 155 & some years only 3 . \\
\hline $1922-23$ & 68 & 142 & \\
\hline $1923-24$ & 59 & 161 & \\
\hline $1924-25$ & 86 & 176 & \\
\hline $1925-26$ & 153 & 158 & \\
\hline $1926-27$ & 129 & 169 & $\downarrow$ \\
\hline $1927-28$ & 77 & 145 & 25 \\
\hline $1928-29$ & 81 & 170 & 12 \\
\hline $1929-30$ & 54 & 169 & 12 \\
\hline $1930-31$ & 75 & 177 & 14 \\
\hline $1931-32$ & 52 & 170 & 20 \\
\hline $1932-33$ & 85 & 161 & 12 \\
\hline
\end{tabular}

Dealing first with the motor drifters (mostly Cornish vessels), it is seen that the number has been well maintained throughout all the postwar years. During the fifteen seasons from 1918-19 to 1932-33, they landed an aggregate weight of 400,355 cwt. of herring as compared with the corresponding aggregate of 635,226 cwt. landed by the steamers. Taking into account the number of motor drifters in comparison with that of the steamers, it is estimated that the steam fishery has been from four to five times as efficient as the motor fleet, so far as weight per fishing unit is concerned.

The number of steamers has not been so steady. The large number of arrivals in 1925-26 and 1926-27, for example, is in marked contrast with those of the seasons from 1929-30 to 1931-32. It is of interest to enquire 
into the reasons for this irregularity in the number of steamers which form so important a section of the fishing power. Data show that there is a rise in the number of steamers in the season which follows one of good fishing. Thus, fishing was good in 1924-25 when 86 steamers came, and in the following season 153 steamers made the trip. Similarly, the good fishing of 1929-30 was followed by the arrival of a larger number of steamers in 1930-31. But the reverse seems to hold good, the number of steamers becoming reduced in the season following poor fishing. In

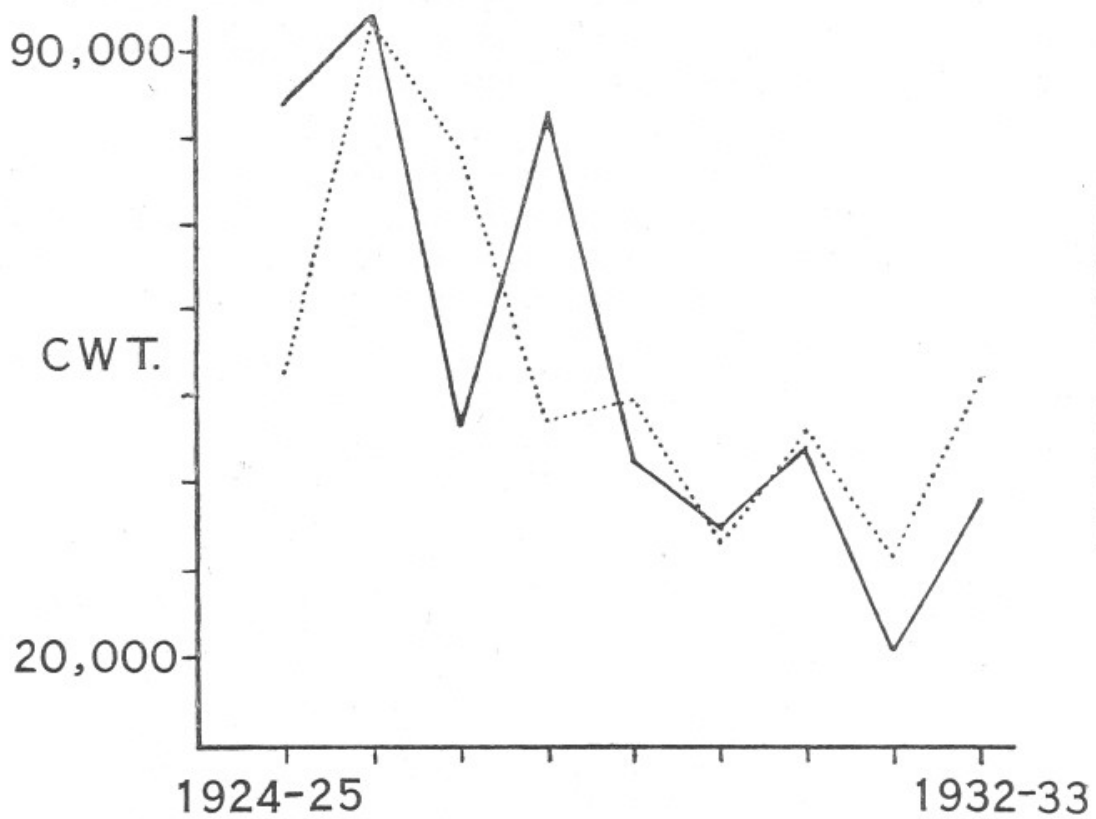

FiG. 1.-Total weight of herrings landed at Plymouth in each season from 1924-25 to 1932-33.

Continuous graph.....Actual weight landed.

Dotted graph.......Hypothetical weight on basis of flat rate of 611 ewt. per steamer per season.

1925-26 fishing was bad, so that fewer steamers came in 1926-27. It was again poor, and the number of steamers was still less in 1927-28.

There are, of course, other influences which help to decide how many steamers will participate in the Plymouth fishery. The Plymouth season follows hard upon a strenuous and extended fishery in the North Sea, culminating in the great East Anglian season. Owners of steamers will know how they have fared thus far, and may or may not be prepared to carry an additional risk at Plymouth. In any event, they are unlikely to send the ships round before they receive some assurance by news from Plymouth that there is at least the chance of making a profitable voyage. 
A matter of some practical importance is the extent to which the total weight of fish landed during a season is affected by changes in the number of visiting steamers. Out of the 1,035,581 cwt. of herrings landed during December and January from 1918-19 to 1932-33, the steamers obtained 635,226 cwt., or over 61 per cent. The latter amount represents the combined result of 1,039 separate steamer-visits, a single visit being the whole or some part of one season. Now if the aggregate weight of fish landed and the total number of steamer-visits had been equally distributed over the fifteen seasons, approximately $42,348 \mathrm{cwt}$. would have been landed each season as the result of 69 steamer-visits. One steamervisit would thus have contributed about $611 \mathrm{cwt}$. to each season's catch. This "spread-over" average is admittedly only a rough estimate of a steamer's fishing efficiency, but it serves the purpose intended. In the following Table the theoretical weight as calculated on the basis of 611 cwt. per steamer-visit is shown in conjunction with the actual weight landed during the seasons from 1924-25 to 1932-33 :-

\begin{tabular}{|c|c|c|c|c|c|}
\hline & & $\begin{array}{l}\text { Theoretical Weight } \\
\text { Landed, on basis of }\end{array}$ & Actual Weight & $\begin{array}{l}\text { Discr } \\
\text { Actual }\end{array}$ & $\begin{array}{l}\text { ancy. } \\
\text { eight is }\end{array}$ \\
\hline Season. & $\begin{array}{l}\text { Number of } \\
\text { Steamers. }\end{array}$ & $\begin{array}{l}611 \text { cwt. per Steamer. } \\
\text { (Cwt.) }\end{array}$ & $\begin{array}{l}\text { Landed. } \\
\text { (Cwt.) }\end{array}$ & $\begin{array}{l}\text { More } \\
\text { by : }\end{array}$ & $\begin{array}{l}\text { Less } \\
\text { by : }\end{array}$ \\
\hline $1924-25$ & 86 & 52,546 & 83,647 & 31,101 & \\
\hline $1925-26$ & 153 & 93,483 & 94,248 & 765 & \\
\hline $1926-27$ & 129 & 78,819 & 45,932 & & 32,887 \\
\hline $1927-28$ & 77 & $47, \mathrm{C} 47$ & 82,803 & 35,756 & \\
\hline $1928-29$ & 81 & 49,491 & 42,177 & & 7,314 \\
\hline $1929-30$ & 54 & 32,994 & 34,264 & 1,270 & \\
\hline $1930-31$ & 75 & 45,825 & 44,071 & & 1,754 \\
\hline $1931-32$ & 52 & 31,772 & 20,927 & & 10,845 \\
\hline $1932-33$ & 85 & 51,935 & 47,793 & & 4,142 \\
\hline
\end{tabular}

It is evident from the above Table and the graph in Fig. I, that although the total weight landed yearly is dependent upon the number of steamers engaged, the fluctuation in yield from season to season, is not wholly due to this. In some years, particularly 1924-25 and 1927-28, fishing was much more productive than a flat rate of fishing would indicate, while in others, notably 1926-27 and 1931-32, much less fish was landed than would be expected.

\section{Number of Landings.}

It is common knowledge that the number of drifters which proceed to sea is different from day to day. Compulsory stoppages on account of inclement weather, and voluntary cessations from fishing over week-ends and holidays, result in an appreciable loss of fishing time. The motor fishery is the greater sufferer in these respects and anything from 15 to 30 days in December and January in each year pass without a single motor landing. The steam fishery is more fortunate, for the days are rare when at least one steamer does not land. The greater regularity with 
which the steamers are able to operate is exemplified by the following statistics for the period, December 23rd, 1931, to January 19th, 1932 :-

\begin{tabular}{|c|c|c|c|}
\hline Date & Steamer & Motor & \\
\hline $1931-32$. & Landings. & Landings. & \\
\hline Dec. 23 & 20 & 90 & \\
\hline 24 & 20 & - & \\
\hline 25 & 15 & - & Christmas Day \\
\hline 26 & 26 & - & Boxing Day \\
\hline 27 & 27 & - & Sunday \\
\hline 28 & 28 & 10 & \\
\hline 29 & 30 & 20 & \\
\hline 30 & 35 & 50 & \\
\hline 31 & 35 & 70 & \\
\hline Jan. 1 & 30 & 60 & \\
\hline 2 & 30 & 12 & \\
\hline 3 & 28 & 1 & Sunday \\
\hline 4 & 31 & - & \\
\hline 5 & 25 & - & \\
\hline 6 & 25 & - & \\
\hline 7 & 30 & 70 & \\
\hline 8 & 31 & 95 & \\
\hline 9 & 31 & 100 & \\
\hline 10 & 3 & - & Sunday \\
\hline 11 & 31 & - & \\
\hline 12 & 28 & 80 & \\
\hline 13 & 24 & - & \\
\hline 14 & 28 & 70 & \\
\hline 15 & 9 & - & \\
\hline 16 & 31 & 90 & \\
\hline 17 & 20 & - & Sunday \\
\hline 18 & 31 & 4 & \\
\hline 19 & 30 & 80 & \\
\hline
\end{tabular}

The steadiness with which the steamers fish is a valuable asset to the fishery as a whole since it tends to secure that desirable evenness in daily supply of fish for the market. Withdraw the steamers from Plymouth and supplies would fluctuate very seriously from day to day, with the result that the market would cease to attract the important class of buyer who is mainly interested in large and regular supplies of fish. This in its turn might easily lead to the more frequent occurrence of a glutted market in which price falls to a very low level because of a weakening demand. If for no other reason than this steady fishing, the steamers are a highly important section of fishing power, and a permanent reduction in their numbers would be a disquieting factor.

\section{Size of Catches.}

The amount of fish landed in any one season depends not only upon the amount of fishing power expended, but also upon the yield of the fishing. It is characteristic of the fishery that results are outstandingly good in some seasons and correspondingly bad in others; that heavy catches are made on one day and light ones on another; that on one and the same day, some boats land many fish, whereas others return to port empty. 


\section{Seasonal results.}

The average weight per landing by steamers and motors in each of the seasons from 1924-25 to $1932-33$ is shown in Table IV.

\begin{tabular}{ccc}
\multicolumn{3}{c}{ TABLE IV. } \\
$\begin{array}{c}\text { Season. } \\
\text { (Dec. and }\end{array}$ & $\begin{array}{c}\text { Average Weight per Landing (Cwt.). } \\
\text { Jan.). }\end{array}$ & Steamers. \\
$1924-25$ & $40 \cdot 0$ & $20 \cdot 5$ \\
$1925-26$ & $23 \cdot 1$ & $25 \cdot 9$ \\
$1926-27$ & $16 \cdot 6$ & $15 \cdot 9$ \\
$1927-28$ & $46 \cdot 3$ & $24 \cdot 6$ \\
$1928-29$ & $27 \cdot 5$ & $23 \cdot 5$ \\
$1929-30$ & $39 \cdot 1$ & $42 \cdot 5$ \\
$1930-31$ & $32 \cdot 7$ & $23 \cdot 3$ \\
$1931-32$ & $17 \cdot 6$ & $9 \cdot 2$ \\
$1932-33$ & $34 \cdot 2$ & $20 \cdot 2$ \\
\hline & Average $30 \cdot 8$ & Average $22 \cdot 8$
\end{tabular}

Looking down the results of the steam fishing it is seen that in the seasons 1924-25, 1927-28 and 1929-30, the average weight per landing was well above the mean value for the period, whereas in 1926-27 and 1931-32 it fell much below the mean. The same applies to motor landings with the single exception that the yield in 1924-25 was not outstanding. Full consideration of the probable reasons why fishing should have been very good in the three seasons mentioned, but bad in the other two, must be deferred until the biological investigations have been described. It may be said, however, that this is just what might be expected from a knowledge of the fishable stocks which frequented the grounds in those seasons.

\section{The Drift-net as a Snare.}

Variation in the size of catches arises in consequence of the nature of the fishing implement. Skippers, men of experience in the art of drifting, making full use of their knowledge and beliefs, may manœuvre their vessels to the berth they consider the best available at the moment for catching fish, but all their skill cannot ensure a good catch every time the nets are shot. This is because the instrument of capture, the drift-net, is a snare in which fish are caught only as they themselves enter it. Practical experience in drifting and a knowledge of local conditions are indispensable aids in deciding where it is best to set the snare, but the size of the catch depends upon the behaviour of the fish in the immediate neighbourhood of the set nets.

In an interesting paper, Graham (22) deals with the phenomenon of the "swim," which he defines thus: "Something happens limited in time, and space, the result of which is that herring are caught in the nets, in numbers from say five thousand to a quarter of a million per fleet of nets ; 
this phenomenon is called a 'swim' of herring." His provisional explanation of the swim is "that herring, in a normal state, can see the nets and avoid them, so that the sea may be full of herring, yet none caught. When, however, they are under the influence of crowd excitement (due to panic, sexual excitement or migratory impulse) herring are more or less unable to see the net, and are caught." Whether Graham's explanation holds good at Plymouth, it is impossible at present to say, but there is no doubt whatever about the fact that catches are very unequal among the vessels. working in close proximity on the same night, or that catches are frequently heavier on some nights than on others.

\section{The Effect of Gales.}

A connection between stormy weather and herring catches has evidently been long recognised by Cornish fishers. Thus, Dunn (3) writes concerning herrings which annually visit Mevagissey Bay for spawning :-

"One fact is certain, that they exist closely hidden near the shore; and here they would live in undisturbed possession of their haunts but for the storms of winter, especially those blowing directly on the coast. When these happen the fish immediately leave their hidden recesses and move out into the open bay. It is only then our fishermen at Mevagissey are able to catch them; hence our fishers are always waiting for a storm, their nets being moored with anchors at each end in the bay throughout the winter. If only an ordinary gale comes, the inside nets will get most of the fish caught; after a violent storm the herrings will be caught in all the nets ; if there is only a strong breeze the fish will not move from their haunts. If a severe tempest is approaching the coast, the herrings by some intuitive knowledge will move out before it comes."

In an endeavour to test this belief, the strength of the wind as recorded by the Plymouth (Mount Batten) Station of the Royal Air Force and published in the Daily Weather Report of the Meteorological Office, London, has been studied in association with data on daily landings of herrings. The general procedure has been to note the wind at 1300 G.M.T., when boats are normally proceeding to sea, and at 1800 G.M.T., when the fleet is taking up position at sea on the fishing grounds. These records have then been entered in a table, opposite the catch made during the night and landed on the following morning. Working in this way through the data for the past few seasons, distinct correlation between wind and fishing results has been observed.

Reference has already been made to the fact that strong gales prevent the motor fleet from leaving harbour, but it has now to be noted that when the motors are able to resume fishing once more, catches for a few days are much above the average. Bearing in mind the suggestions made 
by Graham, it is as if a gale from a southerly quarter sets the fish on the move, so that many are caught. As a first example, the results for December, 1928, will be considered. There were two periods when the motor boats were prevented from fishing because of strong winds, viz. December 10th-11th, and December 22 nd-26th. Table $V$ gives data regarding the strength and direction of the wind,* and the fishing results for a few days before and after these enforced stoppages :-

\section{TABLE V.}

Wind Records and Fishing Results during December, 1928.

\begin{tabular}{|c|c|c|c|c|c|c|c|c|}
\hline \multirow{7}{*}{$\begin{array}{c}\text { Day of } \\
\text { Month. } \\
4 \\
5 \\
6 \\
7 \\
8\end{array}$} & \multicolumn{4}{|c|}{ Wind. } & \multicolumn{4}{|c|}{ Fishing Results by Motor Boats. } \\
\hline & 1300 & I.T. & $1800 \mathrm{G}$ & & $\begin{array}{l}\text { Day of } \\
\text { Month. }\end{array}$ & $\begin{array}{l}\text { No. of } \\
\text { Landings. }\end{array}$ & $\begin{array}{l}\text { Ave } \\
\text { per L }\end{array}$ & $\begin{array}{l}\text { age weight } \\
\text { anding (cwt.). }\end{array}$ \\
\hline & W & 1 & NW & 1 & 5 & 60 & $17 \cdot 5)$ & \\
\hline & $\mathrm{N}$ & 3 & NNW & 2 & 6 & 50 & 14 & Average weight \\
\hline & SW & 6 & NW & 3 & 7 & 30 & 6 & prior to stop- \\
\hline & NW & 3 & ENE & 2 & 8 & 30 & 19 & page $=17 \mathrm{cwt}$. \\
\hline & NNE & 4 & $\mathrm{~N}$ & 1 & 9 & 7 & 28 & \\
\hline 9 & - & 0 & SW & 4 & 10 & no fishing & - & \\
\hline 10 & $\mathbf{S}$ & $y$ & SSE & 6 & 11 & Ho Hsinng & - & \\
\hline 11 & $\mathrm{E}$ & 2 & SE & 2 & 12 & 70 & $14 \cdot 5)$ & \\
\hline 12 & NE & 3 & NE & 3 & 13 & 70 & 59 & Average weight \\
\hline 13 & ENE & 3 & $\mathrm{E}$ & 4 & 14 & 80 & 73 & after stoppage \\
\hline 14 & SE & 5 & NE & 4 & 15 & 30 & 96 & $=60 \mathrm{cwt}$ \\
\hline 15 & ENE & 3 & $\mathrm{~S}$ & 4 & 16 & 30 & 59 & \\
\hline 18 & ENE & 3 & SSW & 4 & 19 & 40 & 19 & \\
\hline 19 & SW & 3 & W & 3 & 20 & 30 & 17 & prior to stop. \\
\hline 20 & NNW & 4 & NNW & 4 & 21 & 10 & 26 & \\
\hline 21 & - & 0 & E & 2 & 22 & 4 & 15 & \\
\hline 22 & W & 3 & W & 4 & 23 & & - & \\
\hline 23 & WNW & 2 & ESE & 2 & 24 & & - & r \\
\hline 24 & SW & 6 & SW & 7 & 25 & no fishing & - & \\
\hline 25 & SW & 4 & SW & 6 & 26 & & - & \\
\hline 26 & W & 4 & NNW & 4 & 27 & & - & \\
\hline 27 & ESE & 3 & SE & 4 & 28 & 10 & 52 & \\
\hline 28 & W & 4 & WSW & 4 & 29 & 12 & 55 & $\begin{array}{l}\text { Average weignt } \\
\text { after stoppage }\end{array}$ \\
\hline 29 & W & 5 & WSW & 6 & 30 & 14 & 43 & $=54 \mathrm{cwt}$. \\
\hline 30 & WNW & 4 & NNW & 4 & 31 & 16 & 66 & \\
\hline
\end{tabular}

* For the convenience of readers, the following official description of the Beaufort Scale Numbers is given :-

$\begin{array}{cccc}\begin{array}{c}\text { Beaufort Scale } \\ \text { No. }\end{array} & \begin{array}{c}\text { Statute Miles } \\ \text { per hour. }\end{array} & \begin{array}{c}\text { Beaufort Scale } \\ \text { No. }\end{array} & \begin{array}{c}\text { Statute Miles } \\ \text { per hour. }\end{array} \\ 0 & \text { Less than } 1 & 7 & 32-38 \\ 1 & 1-3 & 8 & 39-46 \\ 2 & 4-7 & 9 & 47-54 \\ 3 & 8-12 & 10 & 55-63 \\ 4 & 13-18 & 11 & 64-75 \\ 5 & 19-24 & 12 & \text { Above } 75 \\ 6 & 25-31 & & \end{array}$


It will be observed from Table $\mathrm{V}$ that the average weight per landing for the motor boats is very much greater on the days following a temporary stoppage of fishing than on those prior to the cessation. Moreover, during the stoppages themselves, the wind has blown for some time at strengths of Beaufort Scale Numbers 6 and 7 from a southerly quarter.

Similarly for the season 1929-30. During practically the whole of the first fortnight of December, 1929, the weather was wild and tempestuous, and only 3 landings were made in the 9 days from December 4 th to December 12th, the market being blank for 7 days on end. On December $16 \mathrm{th}$, however, 50 landings were made by motor boats with the remarkable average landing of $161 \mathrm{cwt}$. Next day there were 70 motor landings. averaging $171 \mathrm{cwt}$. Thereafter, the weather remaining favourable, many motor boats were able to fish each night, but the average fell off each day, first to 83 cwt., then to 80 cwt., and was only 14 cwt. on December 20th, and 27 cwt. on December 21st. Only a few steamers had arrived at Plymouth in time for this heavy fishing, but those few obtained results. similar to those of the motors. Thus, on December 16th, one steamer made a landing of 385 cwt. ; on the $17 \mathrm{th}, 4$ steamers averaged $350 \mathrm{cwt}$., per landing; on the 18th, 6 averaged 334 cwt., and on the 19th, a total of 17 averaged 288 cwt. But on December 20th, when 12 steamers landed, the average per landing fell to $50 \mathrm{cwt}$., and it stood at the still lower value of 24 cwt. on December 21st. During January, 1930, the steamers made extra heavy landings on the three days, January 12th, 13 th and 14 th, the averages being 70,75 and $67 \mathrm{cwt}$. respectively. Winds. from SSW and SW of Beaufort Scale Numbers 6 to 8 were blowing on January 9th and 10th, moderating on the 11th. Thus, with fishing. resumed after the gale, catches were of a high order.

The season 1932-33 is of particular interest in this apparent connection between strength of wind and fishing yield. The following is an analysis. of the season's catch :-

\section{Period.}

Dec. 1st to Dec. 6th Dec. 7th to Dec. 11th Dec. 12th to Dec. 18th Dec. 19th to Dec. 26th Dec. 27th to Jan. 3rd Jan. 4th to Jan. 6th Jan. 7 th to Jan. 14th Jan. 15th to Jan. 25th

Whole season

\begin{tabular}{|c|c|c|c|c|}
\hline :— & Total & & Avera & per \\
\hline & Weight & Average & Lan & \\
\hline $\begin{array}{l}\text { Number } \\
\text { of Days. }\end{array}$ & $\begin{array}{l}\text { Landed. } \\
\text { ewt. }\end{array}$ & $\begin{array}{l}\text { Per Day. } \\
\text { cwt. }\end{array}$ & $\begin{array}{l}\text { Steamer. } \\
\text { cwt. }\end{array}$ & $\begin{array}{l}\text { Motor. } \\
\text { cwt. }\end{array}$ \\
\hline 6 & 165 & 27 & 3 & 2 \\
\hline 5 & 2,540 & 508 & 45 & 23 \\
\hline 7 & 36,525 & 5,246 & 67 & 32. \\
\hline 8 & 6,941 & 868 & 19 & 10 \\
\hline 8 & 6,760 & 845 & 21 & 10 \\
\hline 3 & 13,305 & 4,435 & 37 & 33. \\
\hline 8 & 11,750 & 1,469 & 22 & 14 \\
\hline 11 & 1,546 & 141 & 14 & 11 \\
\hline 56 & 79,532 & 1,420 & $34 \cdot 2$ & $20 \cdot 2$ \\
\hline
\end{tabular}

It is apparent from the above figures that daily results were very uneven. The two periods, December 12th to 18th and January 4th to 6 th, were by far the most productive as regards total weight of fish landed. 
Nearly one-half of the season's catch was landed in the seven days of the first of these periods, and another one-sixth in the three days of the second. The weight per landing for both steamers and motors was also very high. Although not so profitable in total yield, the period from December 7 th to 11 th was characterised by a heavy average weight per landing.

During the season, there were two periods of strong gales, the first in. early December, and the second in the beginning of January.* From 1300 G.M.T. on December 6th until 0700 on December 12th the wind records taken three times daily at Mount Batten did not fall below Beaufort Scale 6 except on two occasions, and Beaufort Scale 8 was recorded throughout December 11th. The direction was mainly E.N.E. In consequence, there was no fishing by motor vessels from December 6th to December 11th except by a few larger ones on the night of December 10th. For the twelve landings made, the average was 23 cwt., which, as will be seen from the analysis given above, was fairly high. A number of steamers fished throughout the gale period, their results being good. With the gale moderating during December 12th, all vessels, both motor and steam, were able to fish that night, and on the following morning no less than 10,500 cwt. of fish were landed, representing an average steamer landing of $100 \mathrm{cwt}$. for 39 vessels, and an average motor landing of 66 cwt. for 90 vessels. Thereafter for 4 nights, a full fleet was able to work with very high yield. The second gale period extended from December 31st until January 4th, this time from the southward, with wind force from Beaufort Scale 6 to 8 . There were no landings by motor drifters on January 1st, 2nd and 3rd, and although a good number of steamers continued to fish, the results were not unusually heavy. But with the return of fair weather, enabling full fishing by the motors, high average landings were realised, particularly by the motors. On January 4th, 20 motors made an average landing of $35 \mathrm{cwt}$. ; and on January 5th, 44 motors averaged 56 cwt. per landing, whereas not since December 19th had the average landing been higher than 25 cwt.

The two periods of greatest yield during the 1932-33 season, therefore, immediately followed occasions when the motor fleet had been weatherbound in harbour for some days on end. This experience, together with the other illustrations previously described, seems definitely to suggest that the herrings are in some way affected by the blowing of strong winds, so that fish are caught in great numbers in drift-nets which are set as soon as this becomes practical. There is little evidence as to what actually happens. Strong winds will, of course, increase the turbidity

* Readers will be materially assisted by referring to Cooper's Fig. 1 on p. 56 of this Number. (Cooper, 1.) It should be noted that Cooper adopts the "Mean Cube Beaufort Number " as an index of the capacity of the wind to cause mixing and turbulence in the sea. 
of the water, and possibly this may result in the fish not being able to see the nets so readily. If the fish moved under these circumstances, they would thus be more likely to become enmeshed. Possibly, in addition to increasing the turbidity of the water, strong wind action may actually induce the fish to move, and so increase the chances of fish being gilled. Whatever the cause, the apparent relation between wind and density of landing is one of practical importance.

\section{Inshore Fishing in Bigbury Bay.}

On some days it is noted that the motor boats are making good landings, whereas the steamers are having a poor time. The following are a few examples from the returns of 1931-32:-

\begin{tabular}{|c|c|c|c|c|}
\hline \multirow[b]{3}{*}{$\begin{array}{c}\text { Date. } \\
\text { (1931-32.) }\end{array}$} & \multicolumn{2}{|c|}{ Steamers. } & \multicolumn{2}{|c|}{ Motors. } \\
\hline & & Average & & Average \\
\hline & $\begin{array}{l}\text { No. of } \\
\text { Landings. }\end{array}$ & $\begin{array}{c}\text { Weight. } \\
\text { (cwt.) }\end{array}$ & $\begin{array}{l}\text { No. of } \\
\text { Landings. }\end{array}$ & $\begin{array}{c}\text { Weight. } \\
\text { (cwt.) }\end{array}$ \\
\hline Dec. 19 & 15 & 1.9 & 90 & 12 \\
\hline Jan. 20 & 30 & $1 \cdot 4$ & 120 & 35 \\
\hline Jan. 21 & 20 & $3 \cdot 5$ & 90 & 16 \\
\hline Jan. 27 & 18 & $3 \cdot 5$ & 90 & 12 \\
\hline
\end{tabular}

This occurred when the herrings were located well inshore in Bigbury Bay. These grounds can be worked with safety by the smaller motor craft, but not by the steamers without risk of damage to both boat and gear.

\section{Ray-netting and Trawling in Bigbury Bay.}

Reference may here be made to complaints by drift-net fishermen of interference caused by other methods of fishing. It is alleged that a considerable amount of damage to drift-nets is sustained by fouling with the ropes and moorings of the large-meshed tangle nets set on the bottom in Bigbury Bay for catching rays and turbot. (vide Steven, 31.) At the time of writing, negotiations are proceeding between the Sea Fisheries Committees of Devon and Cornwall, and it is hoped that a satisfactory solution of the difficulty will eventually be reached.

There is also some feeling among local drifting interests that motor trawlers fishing for spawning herrings in Bigbury Bay are doing harm to the stocks. No sound case for this objection can be made out, however, and the Devon Sea Fisheries Committee have decided to take no action.

\section{CONCLUSION}

The yield of the Plymouth winter drift-net herring fishery is subject to daily and seasonal fluctuation. Among the contributory causes of these fluctuations are (1) variation in the number and character of the boats engaged in the fishery, and (2) variations in the intensity with 
which the boats are able to fish. These causes, however, do not fully account for the observed fluctuations in yield, since the results of fishing, good or bad, ultimately depend upon the number and behaviour of the fish on the grounds. It follows, therefore, that it is impossible to give a complete explanation of past fluctuations in yield, or to predict what seems likely to happen in the future, until adequate knowledge of the fish stocks has been acquired.

\section{STUDIES OF THE FISHES LANDED.}

It is convenient to commence this section with a brief summary of the more general facts concerning the herrings caught at Plymouth. Catches include fishes of three classes in varying proportions: (1) "full " fish, in which the roes and milts are sufficiently developed so as to fill or almost fill the body-cavity, (2) spawners, or "maizey" fish, in which the reproductive glands are fully mature and actually in the running condition, (3) spent fish, which for the most part have quite recently spawned. Examination of the stomachs of the fishes shows that there is no feeding. These facts prove that the fishery depends upon a concentration of fish intent on spawning. The fish have not come to feed.

But while the fish agree in the purpose for which they have come, they differ in practically all other respects. In length, individuals vary from $21 \mathrm{~cm}$. to $31 \mathrm{~cm}$. ( $8 \mathrm{in}$. to $12 \mathrm{in}$.) although a sample taken at any time during the season will probably include 50 per cent or more individuals between the lengths of $25 \mathrm{~cm}$. and $28 \mathrm{~cm}$. With regard to weight, Orton (28) has shown that for 1075 individuals the total range of variation is from $72 \mathrm{grm}$. to $218 \mathrm{grm}$. ( $2 \frac{1}{2}-7 \frac{1}{2} \mathrm{oz}$.). Age is also variable. Fishes are mostly in the 3 rd to the 7 th or 8 th winter of life, but an occasional individual in its 2 nd winter may occur, and those in their 9th, or even older, are not uncommon. In structure and body proportions, individuals differ in such features as the size of the eye, the depth of the body, and the number of bony rays in the fins. They also differ in their number of vertebræ, and it has been shown (Orton, 28 and Ford, 8) that, exclusive of the terminal portion of the backbone known as the urostyle, the number varies from 53 to 58. Another internal difference is in the number of pyloric cæca (Ford, 6).

The interpretation of these differences forms an essential part of the study of the fluctuations of the commercial fishery, and in the pages which follow, an account is given of the conclusions reached.

\section{SPawning and SpawnING-TIME.}

Direct evidence that spawning takes place in the Plymouth district is provided by records of naturally-deposited herring spawn taken by NEW SERIES.-VOL. XIX. NO. 1. AUGUST, 1933. 
Laboratory research vessels, although such records are surprisingly few. Only once in the past ten years has spawn been taken, when on March 3rd, 1930, eggs were brought to the surface in the trawl of s.s. Salpa, working on the Mewstone Grounds. Nevertheless, there are many other observations to show that spawning is intensive locally. It is of interest first to note that Matthias Dunn, the gifted fisherman-naturalist of Mevagissey in Cornwall, has given a description (Dunn, 4) of what he believed was the actual spawning of herrings in Bigbury Bay. He says: "As to the actual spawning of Herrings, we have many times seen this going on on cold nights in December and January, in Bigbury Bay, in from fifteen to twenty fathoms of water. At such times male and female Herrings will congregate together in multitudes, and form themselves into vast columns - possibly slightly pyramidal in form-reaching from the surface to near the bottom, when they will commence a violent perpendicular action. Sometimes the top will be more than one hundred yards in diameter, and, when the column is in full swing, the mass often appears like a boiling cauldron. The uninitiated could not surmise the cause of such a perpetual din and clatter from this up-and-down motion as may be heard near by. This goes on without any horizontal movement being visible. Nor will any ordinary noise disturb them, so intent are they on their work; and the relative position of the fish and the fishing-boats near them will often remain the same for an hour or more together. This action, no doubt, presses out the milt and roe from the male and the female, which is evidently dropped in the sea; and the congress of life happens as the ova is sinking to the lower depths, for the spermatozoa floats - or is only of the specific gravity of the water-while the eggs are heavier, and instantly sink. Often the net will come in contact with these columns of spawning fish near their base, some fifty feet under water, and there Herrings will enter the net as thick as at the surface. When such masses are spawning, the whole sea in the neighbourhood will have a milky whiteness, caused by the surplus milt of the male." Whether or not Dunn was right in believing that he had witnessed herrings in the act of spawning, it is impossible to say, but when this talented and experienced observer describes so remarkable a phenomenon, for which no equally satisfactory alternative explanation can be advanced, it is difficult to say that he is wrong.

The presence of large quantities of maizey (spawning) fish in both drift-nets and the trawl, and the numbers of newly-hatched larval herrings which are taken in tow-nets used by the research vessels, bear out the limited direct evidence of spawning grounds inshore at points along the neighbouring coast from off Gribbon Head in Cornwall to the eastward at least as far as Exmouth in Devon. Bigbury Bay has long been regarded as one of the principal areas, no doubt because it is here that spawning shoals are most usually located, but considerable spawning must take 
place in other parts. Dunn (3 and 4) refers to spawning in Mevagissey Bay, while Wallace (36) records a catch of no less than 4210 recentlyhatched larvæ in one $\frac{1}{2}$-hour haul of the young-fish-trawl by s.s. Salpa, working Rame Head, bearing E. 12 miles, on February 5th, 1923 - a record which strongly suggests the presence of a spawning ground near at hand. Early larvæ have also been taken in quantity at points off the Devon coast. Herrings running with spawn have been taken in Plymouth Sound and the estuaries of the Lynher and Tamar, while every year in late December and January, small drifters working out of their home ports of Exmouth, Sidmouth, Beer, etc., and fishing just off the shore in the waters of the Great West Bay, secure catches consisting almost entirely of running fish. These and other records support the belief that spawning takes place over a wider area than is commonly supposed.

It is important to fix the time at which spawning occurs. Running fish have been taken as early as September 30th (Plymouth Sound, 1925 and 1926), and as late as May 14th (trawled by s.s. Salpa, 1930), representing an extreme range of $7 \frac{1}{2}$ months. Moreover, in any one season, spawners and spents may occur in the catches at any time, making it a matter of some difficulty to decide when spawning is most general over the grounds. Observations conducted during the season 1924-25 (Ford, 9, p. 284) indicated that spawners were chiefly in evidence in the catches of late December and the whole of January. The results of later work confirm this, but also show that considerable numbers of spawning fish are in the neighbourhood in February and March, after the drifting season has come to an end, and that these can be, and are, caught in the trawl. There is reason to believe, too, that the amount of spawning which takes place in October and November is considerably less than that in subsequent months. Although no explanation can at present be offered, it may be stated that during the past three seasons (1930-31 onwards), " maizey" fish are almost entirely absent from drift-net landings, even during the months of December and January when they would be expected. Good catches of spawning fish, however, were later secured in the trawl.

It is clear, therefore, that from October onwards, a concentration of herrings, bent on spawning, occurs off the Plymouth coasts. Many of the shoals must arrive some considerable time before the individual fishes are ready to spawn, for the catches in the earlier part of the season consist almost exclusively of " full " but not ripe herrings. Probably these shoals remain in the vicinity until spawning has been accomplished, but it is not unlikely that they are later joined by shoals which are ready to spawn almost as soon as they arrive on the grounds. In any case, it is only possible to explain the " mixed " character of landings by assuming that spawning takes place shoal by shoal throughout the season, with the result that on the same day, one boat will land "full" fish and another 
"spents," while one and the same catch will include fulls, spawners and spents.

\section{VARIATION IN WEIGHT.}

In 1914-15, a comprehensive biometric investigation of a total of 1075 herrings was carried out at the Plymouth Laboratory (vide Orton, 28), which included the determination of the weight of each fish to the nearest gram. The weight was that of the ungutted fish, and the individual variation thus depended not only on the size of the fish, but also on its sexual condition. Variation due to unequal weights of stomach and gutcontents may be ignored since the winter fish at Plymouth hardly ever contain food. Fraser $(16$, p. 251) worked out a formula linking weight with length, on the basis of the data given in Orton's Table III. He found that for the total of 550 records,

$$
\mathrm{W}=0 \cdot 00000337 \times \mathrm{L}^{3 \cdot 149}
$$

Where $\mathrm{W}=$ Weight in grammes.

$\mathrm{L}=$ Length in millimetres.

Fraser's formula does not take into account the individual differences in sexual condition which occur among a season's catches, but may be taken to apply to "full" fishes. From an analysis of the data given in Orton's Table IV, where the weights refer particularly to spawning fish (maturity stage VI) and spents (maturity stages VII and II), it appears as if spawning females are slightly heavier than spawning males of a similar length, while, as expected, the spents of both sexes are not so heavy as the fulls. But as the standards of sexual maturity are not sufficiently precise, no useful purpose is served in making more detailed comparisons.

\section{The Age of Fishes Landed.}

During each of the eight seasons from 1924-25 to 1931-32, estimates of the age of the herrings landed were made from their scales. Two or three scales from each fish, separately picked from the anterior region of the body near the tip of the pectoral fin, were cleaned between finger and thumb in water and mounted on a numbered glass slide, using a mixture of egg-albumin and glycerine as the adhesive. In reading a scale, the number of "summer zones" and the number of "winter rings" were both recorded (see Ford, $\%$, p. 243), the clear winter-edge being counted as a completed ring. Records of age were then grouped into year-classes according to the calendar year in which the first summer zone was formed on the scale. For example, fishes caught during the season of 1924-25 which showed five summer zones and four winter rings within the winter edge, were recorded as " 5 zoned 5 ringed " and assigned to the 1920 
year-class. Normally, fishes older than "6-zones 6-rings" were recorded as " old " fish without any attempt to fix the age with precision.

In actual practice it was found that catches taken during the two most important months of December and January of any one season agreed sufficiently closely to warrant the calculation of a seasonal average agecomposition, giving in the form of percentages the relative numbers of fishes of different ages likely to be taken in a catch at any time during that season. In the following Table VI the average percentages, according to age, are given for the eight seasons :-

\section{TABLE VI.}

\begin{tabular}{|c|c|c|c|c|c|}
\hline Season. & \multicolumn{5}{|c|}{ Percentage Numbers of Fish at the following Age. } \\
\hline (Dec.-Jan.) & 3 & 4 & 5 & 6 & Older than 6 \\
\hline $1924-25$ & $7 \cdot 0$ & $12 \cdot 3$ & $56 \cdot 0$ & $15 \cdot 3$ & $9 \cdot 4$ \\
\hline $1925-26$ & $5 \cdot 3$ & $15 \cdot 2$ & $14 \cdot 1$ & $47 \cdot 5$ & $17 \cdot 9$ \\
\hline $1926-27$ & $4 \cdot 7$ & $27 \cdot 9$ & $22 \cdot 9$ & $10 \cdot 7$ & $33 \cdot 7$ \\
\hline $1927-28$ & $18 \cdot 6$ & $20 \cdot 4$ & $30 \cdot 9$ & $12 \cdot 0$ & $17 \cdot 1$ \\
\hline $1928-29$ & $3 \cdot 3$ & $30 \cdot 8$ & $19 \cdot 5$ & $26 \cdot 6$ & $19 \cdot 3$ \\
\hline $1929-30$ & $1 \cdot 9$ & $18 \cdot 1$ & $35 \cdot 9$ & $15 \cdot 4$ & $28 \cdot 8$ \\
\hline $1930-31$ & $4 \cdot 4$ & $10 \cdot 2$ & $23 \cdot 8$ & $33 \cdot 2$ & $28 \cdot 3$ \\
\hline $1931-32$ & $3 \cdot 4$ & $12 \cdot 6$ & $15 \cdot 0$ & $21 \cdot 3$ & $47 \cdot 7$ \\
\hline & $6 \cdot 1$ & $18 \cdot 4$ & $27 \cdot 3$ & $22 \cdot 7$ & $25 \cdot 3$ (Tot \\
\hline
\end{tabular}

It is evident from the figures that the composition by age varies considerably from one season to the next. An important feature of this agevariation, however, is more clearly seen when the age data are rearranged according to the year-classes which they represent. This has been done in Table VII :-

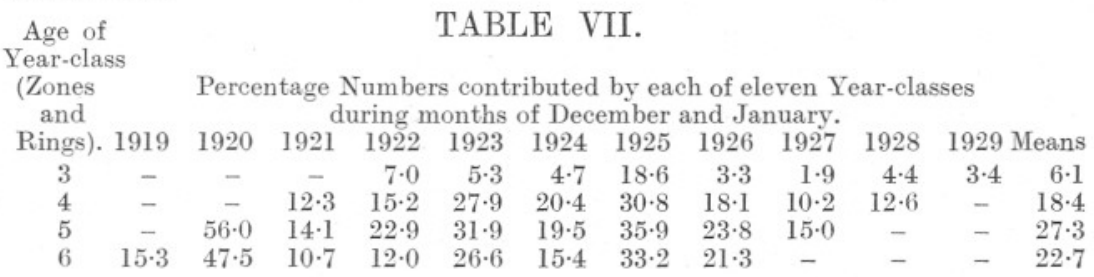

Looking down the columns of Table VII it is seen that year-classes agree almost without exception in the order of the rise and fall of the percentage from the third to the sixth year. The percentage is comparatively low in the third year, rises to a maximum in the fifth, and commences to fall in the sixth. There is but one departure from this, in that year-class 1924 gave a greater percentage in its fourth year than in its fifth.

This agreement among year-classes was noted in an earlier report (Ford, 11, p. 14) when only the results for the four seasons 1924-25 to 1927-28 were available for study. That it should hold good over the longer period of eight seasons suggests that we have to deal with something more than 
a fortuitous coincidence of figures, the observed agreement strongly indicating that younger year-classes replace older ones in a regular manner as the seasons go by. In considering this process of replacement, however, it is important to remember that the data relate to commercial catches as distinct from the fish-stocks from which the catches were drawn. It is true that the characters of a catch bear real relationship to the characters of the stock fished, but the former are also dependent upon the size of mesh in the nets used. Since no important alteration from season to season in the size of mesh is known to occur, the selective action of fishing may be ignored, provided that the distinction between catch and stock is recognised. The results summarised in Tables VI and VII thus show the process of replacement of older year-classes by younger, in the fishery. Each yearclass in turn enters the fishery in its third year, reaches its maximum proportion in the catches during its fifth year, and begins to fall out in its sixth.

Further reference to Table VII shows that there is little uniformity in the contributions made by successive year-classes at the same age. Those of 1920, 1923 and 1925 gave comparatively large percentages throughout the third to the sixth years of life, whereas those of 1921, 1927 and 1928 gave correspondingly poor ones. This outstanding importance of certain year-classes and the comparative absence of others are highly significant matters which will be dealt with more fully at a later stage (p. 370). It will suffice at present to point out that in their fifth and most important year, fishes of year-classes 1920, 1923 and 1925 formed $56.0 \%, 31.9 \%$ and $35.9 \%$ respectively, of the season's catch. Not only this, for each in its turn remained a most important element of the catches for two or even three seasons in succession.

Before leaving this study of age-composition, attention must be drawn to the fact that all the above considerations have had to do with percentage-composition of catches and not with absolute numbers. The data tell us how many out of every hundred fish caught are of a certain age or belong to a given year-class, but they give no idea as to the absolute numbers of such fishes landed. This fact will also be recalled later.

\section{Length in Relation to Age.}

It has already been stated that the length of the herrings at Plymouth varies between the limits of about $21 \mathrm{~cm}$. to $31 \mathrm{~cm}$. Since length increases with age, one might have expected that fishes of the same age-group would be of approximately the same length, but it is actually found that there is a wide variation in the length of fishes of the same age-group. The result is that it is quite impossible to obtain anything approaching a reliable estimate of the length of a fish merely by noting its age, or vice-versa. For example, a 3-zoned 3-ringed fish may be any length from $21 \mathrm{~cm}$. to 
$29 \mathrm{~cm}$., while an individual measuring $25 \mathrm{~cm}$. in length might prove to be any age from 3 years upwards. The following Table VIII summarises results obtained during the four seasons from 1924-25 to 1927-28, and will serve to show the range and extent of the length-variation according to age :-

\section{TABLE VIII.}

\begin{tabular}{|c|c|c|c|c|c|c|c|c|c|c|c|c|c|c|c|}
\hline \multirow[t]{2}{*}{ Age-group. } & Season. & Year- & & No. & of fis & hes i & n each & of 11 & lengt & th gro & ups & (cm.). & & Total & $\begin{array}{l}\text { Average } \\
\text { length. }\end{array}$ \\
\hline & & class. & 21 & 22 & 23 & 24 & 25 & 26 & 27 & 28 & 29 & 30 & 31 & No. & $(\mathrm{cm})$. \\
\hline \multirow{3}{*}{ zoned 3-ringed } & $\begin{array}{l}1924-25 \\
1925-26\end{array}$ & $\begin{array}{l}1922 \\
1923\end{array}$ & $\overline{2}$ & $\begin{array}{r}3 \\
10\end{array}$ & $\begin{array}{r}19 \\
9\end{array}$ & $\begin{array}{l}39 \\
32\end{array}$ & $\begin{array}{l}68 \\
44\end{array}$ & $\begin{array}{l}36 \\
13\end{array}$ & $\begin{array}{r}15 \\
3\end{array}$ & $\begin{array}{l}3 \\
-\end{array}$ & 1 & $\begin{array}{l}- \\
-\end{array}$ & $\begin{array}{l}- \\
-\end{array}$ & $\begin{array}{l}184 \\
113\end{array}$ & $\begin{array}{l}25 \cdot 5 \\
24 \cdot 9\end{array}$ \\
\hline & $1926-27$ & 1924 & - & - & 4 & 11 & 33 & 27 & 12 & - & - & - & - & 87 & $25 \cdot 9$ \\
\hline & $1927-28$ & 1925 & 4 & 18 & 57 & 71 & 34 & 4 & 1 & 1 & - & - & - & 190 & $24 \cdot 2$ \\
\hline \multirow{4}{*}{ zoned 4-ringed } & $1924-25$ & 1921 & - & - & 6 & 13 & 34 & 67 & 72 & 53 & 10 & 2 & - & 257 & $27 \cdot 0$ \\
\hline & $1925-26$ & 1922 & - & 4 & 11 & 33 & 59 & 94 & 87 & 22 & - & - & - & 310 & $26 \cdot 4$ \\
\hline & $1926-27$ & 1923 & - & 2 & 13 & 59 & 88 & 46 & 19 & 14 & 2 & - & - & 243 & $25 \cdot 7$ \\
\hline & $1927-28$ & 1924 & - & 2 & 26 & 49 & 66 & 32 & 9 & 3 & 1 & 1 & - & 189 & $25 \cdot 3$ \\
\hline \multirow{4}{*}{ zoned 5-ringed } & $1924-25$ & 1920 & - & - & - & 11 & 96 & 304 & 481 & 251 & 33 & 4 & 1 & 1181 & $27 \cdot 4$ \\
\hline & $1925-26$ & 1921 & - & - & - & 10 & 35 & 58 & 79 & 37 & 12 & 2 & - & 233 & $27 \cdot 1$ \\
\hline & $1926-27$ & 1922 & - & - & 3 & 21 & 54 & 65 & 48 & 25 & 2 & - & - & 218 & $26 \cdot 5$ \\
\hline & $1927-28$ & 1923 & - & - & 2 & 25 & 120 & 105 & 44 & 5 & - & - & - & 301 & $26 \cdot 1$ \\
\hline \multirow{4}{*}{ zoned 6-ringed } & $1924-25$ & 1919 & - & - & 1 & 2 & 12 & 59 & 140 & 65 & 26 & - & - & 305 & $27 \cdot 6$ \\
\hline & $1925-26$ & 1920 & - & - & - & 6 & 37 & 106 & 250 & 304 & 97 & 6 & - & 806 & $27 \cdot 9$ \\
\hline & $1926-27$ & 1921 & - & - & - & 4 & 10 & 21 & 34 & 18 & 9 & 2 & - & 98 & $27 \cdot 4$ \\
\hline & $1927-28$ & 1922 & - & - & - & 7 & 27 & 31 & 31 & 8 & 5 & - & - & 109 & $26 \cdot 7$ \\
\hline
\end{tabular}

That fishes of the same age-group may differ in length to the degree indicated in Table VIII is a matter which requires further consideration. A certain amount of this difference in length may be due to the fact that fishes of the same age-group are not necessarily all of the same absolute age. And this is because the method of estimating age from the number of rings and zones on the fish's scale is not able to distinguish between fishes born at different times during the same spawning season. With an extended spawning season like that at Plymouth, fishes of the same yearclass may thus differ in absolute age by as much as five to six months.

Length, however, is not solely a function of age, although it is known that a herring adds something to its length during every year of its life. There is little reason for believing that two fishes, born on the same day, will reach exactly the same length after a given interval of time.

The interpretation of observed differences in length therefore necessitates enquiries in a number of different directions, the more important of which will now be dealt with.

\section{Length $\left(l_{1}\right)$ at formation of First Winter Ring.}

It is characteristic of the Plymouth fish that the length $l_{1}$ at which the first winter ring is formed on the scale varies within wide limits. (Ford, 9, p. 294.) Thus, for a total of 1122 fishes of year-class 1920 
examined in the winter of $1924-25, \mathrm{l}_{1}$ varied from $6.5 \mathrm{~cm}$. to $18.5 \mathrm{~cm}$. Similarly, a total of 244 fishes of year-class 1921, also examined in the winter of 1924-25, varied from $8.5 \mathrm{~cm}$. to $17.5 \mathrm{~cm}$. In both instances, the individual values were widely dispersed over the total range of variation, so that the averages were subject to a large probable error.

\section{Length $\left(l_{2}\right)$ at formation of Second Winter Ring.}

The length $\mathrm{l}_{2}$ is also very variable. Thus, for the 244 fishes of year-class. 1921 in which $l_{1}$ varied from $8.5 \mathrm{~cm}$. to $17.5 \mathrm{~cm}$., the value of $l_{2}$ varied from $16.5 \mathrm{~cm}$. to $25 \cdot 5 \mathrm{~cm}$., and the average $\mathrm{l}_{2}$ was also subject to a large probable error.

\section{Correlation between the Values of $l_{1}$ and $l_{2}$.}

In an individual fish, the difference between $l_{1}$ and $l_{2}$ is the total amount. added to the length during the year which intervenes between the formation of the first and second winter rings on the scale. But, as has already been shown, the absolute age of the fish at the time when this increment was added cannot be stated with complete precision. Hence, a comparison between the observed values $l_{1}$ and $l_{2}$ for a number of fishes is in reality a comparison of the growth of fishes which probably differ in absolute age. Error from this source can be reduced to the minimum by first subdividing the fishes into groups according to the value of $l_{1}$ and then noting the value of $l_{2}$ for each of the groups. For the 4-zoned 4-ringed fishes of year-class 1921 referred to above, the following are the results:-

\begin{tabular}{|c|c|c|c|c|c|c|c|c|}
\hline alues of $i$ & $\begin{array}{c}9.5 \\
\cdot \quad 17.93\end{array}$ & & & & & & & \\
\hline & $8 \cdot 43$ & & $8 \cdot 0$ & & $7 \cdot 3$ & $6 \cdot 72$ & 6. & 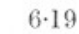 \\
\hline
\end{tabular}

It is seen that the size of the growth increment $\left(t_{2}\right)$ depends upon the length $l_{1}$, so that the larger the value of $l_{1}$, the smaller the increment. Statistical treatment of the data shows that the correlation between $l_{1}$ and the increment $t_{2}$ is significant. Hence it is possible to determine a regression equation of the form $l_{2}=\mathrm{ml}_{1}+\mathrm{c}$ which will give values of $l_{2}$ closely approximating to the observed data. Similar regression equations may be determined linking $l_{3}$ with $l_{2}, l_{4}$ with $l_{3}$. . . etc. (Ford, ry, p. 249.)

\section{"Compensatory Growth."}

This correlation between the length of a herring at the formation of a given winter-ring and the increment of length which will be added before the next ring is laid down, has been noted by other workers. For example, Watkin (37) writes: "It is a feature of the growth of the herring that each succeeding year's growth is less than that of the preceding year. . . . It also seems to be a general feature that the herring. 
should approach a certain length at the completion of each of the various. years' growth. If for some cause or other the fish was unable to complete this amount of growth in a particular year then it will in some measure make up the deficiency the following year, so that what may be called the phenomenon of compensatory growth is characteristic of the herring."

More recently, however, Hodgson (26) has studied the matter in an interesting way, to arrive at the conclusion that this so-called "compensatory growth " is simply explained as the natural result of comparing the growth of fishes which are at different ages. For convenience, his Fig. 30 is here reproduced as Fig. 2 below. He draws a curve AB, which he terms "the curve of ability to grow," passing through a value $8.5 \mathrm{~cm}$. on the axis XY. This curve intersects the ordinate op at point $\mathrm{G}$.

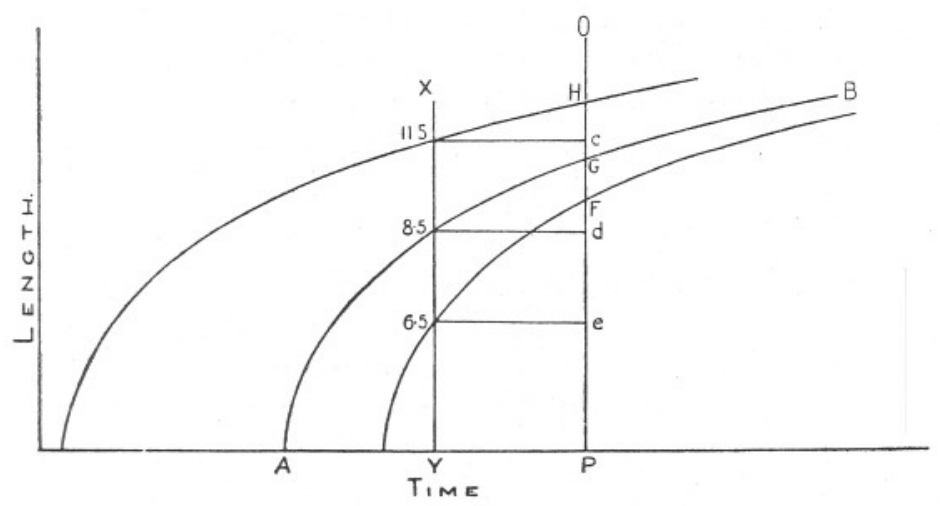

FIG. 2.-Reproduction of Fig. 30 in Hodgson (26). For explanation see present Text, above.

The growth made in the interval of time yP is thus given by the length ad on the ordinate op. Hodgson now moves curve $\mathrm{AB}$ to the left, keeping point $\mathrm{A}$ on the time-axis, until the curve cuts the $\mathrm{XY}$ axis at a value of $11.5 \mathrm{~cm}$. instead of $8.5 \mathrm{~cm}$. Under these circumstances, the growth made in the time-interval YP is given by the length $\mathrm{Hc}$ on the ordinate oP instead of $\mathrm{Gd}$. Alternatively, the curve $\mathrm{AB}$ is moved to the right, still keeping point $\mathrm{A}$ on the time-axis, until it cuts XY at $6.5 \mathrm{~cm}$. In this case the growth in the time-interval YP is given by Fe on the ordinate op. With these things done, it is seen that $\mathrm{Fe}>\mathrm{Gd}>\mathrm{Hc}$. That is to say, the growth made during the time $\mathrm{YP}$ is dependent upon the value on the $\mathrm{XY}$ axis through which the curve passes, the largest growth being given by the smallest value, $6.5 \mathrm{~cm}$., and the smallest growth by the largest value, $11.5 \mathrm{~cm}$. The sole explanation of this is that the curve AB has been started at a different point in time on the time-axis. There is no question of a difference in growth-rate, or any kind of compensatory growth, for the form of the curve has been unchanged. 
The first point to be raised in connection with Hodgson's study is his " curve of ability to grow." The growth of the herring from year to year is not continuous and uniform. Seasons of growth alternate with seasons of no growth. The measurements of scales provide information as to the amounts added from year to year, but they tell us nothing concerning the time and rate at which individual increments are laid down. These facts are, of course, well known to Hodgson, and it may be assumed that he intends his curve merely as a geometric curve to show how the length increases from year to year, rather than as a growth-curve in the stricter sense.

A second point is that Hodgson gives no indication of the particular " form " of his curve AB. Admittedly, this does not affect the validity of the fact that $\mathrm{Fe}>\mathrm{Gd}>\mathrm{Hc}$, but it is important to note that the amount by which $\mathrm{Fe}>\mathrm{Gd}>\mathrm{HC}$ is dependent upon the "form " of the curve as well as upon its position with relation to the time-axis.

Consider the regression equations which show the relation between $l_{1}$ and $l_{2}, l_{2}$ and $l_{3}, l_{3}$ and $l_{4} \ldots l_{n}$ and $l_{n+1}$. They are all of the general form : $\mathrm{Y}=\mathrm{MX}+\mathrm{C}$

where $\mathrm{x}=$ Length of a herring at formation of $n^{\text {th }}$ winter ring.

$$
\begin{aligned}
& \mathrm{Y}=\|, \quad, \quad " \quad n+1^{\text {th }}, \quad, \quad, \\
& \mathrm{M}=\mathrm{A} \text { constant of positive value less than } 1 . \\
& \mathrm{C}=\mathrm{A} \text { constant of positive value greater than } 1 .
\end{aligned}
$$

Treating the equation $\mathrm{y}=\mathrm{Mx}+\mathrm{C}$ purely as a mathematical expression, let us now apply it continuously so that having determined the value of $\mathrm{Y}$ for an initial value of $\mathrm{x}$, we use this as a new value of $\mathrm{x}$ for a further calculation of $\mathrm{y}$, and so on, indefinitely. These are the results :-

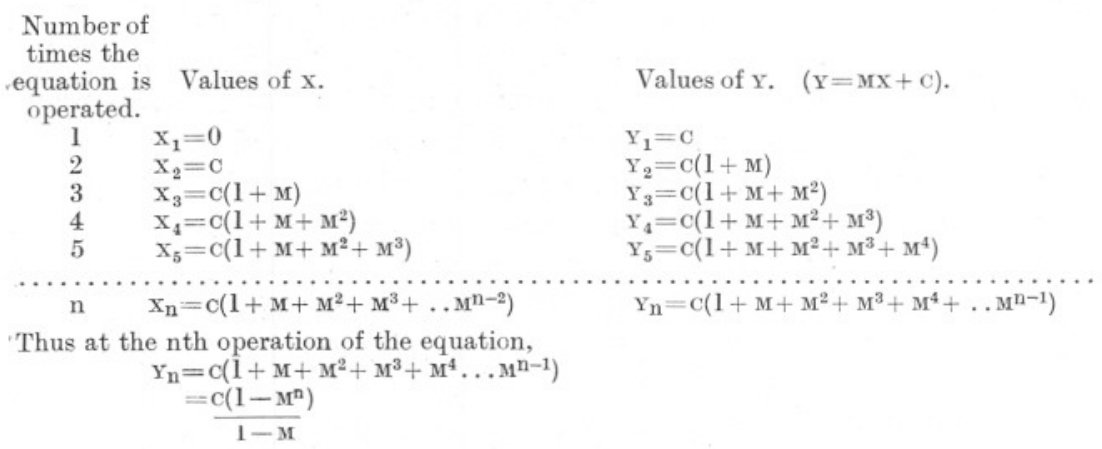

In Fig. 3 the successive values $\mathrm{Y}_{1}, \mathrm{Y}_{2}, \mathrm{Y}_{3} \ldots \mathrm{Y}_{6}$ when the initial value $\mathrm{X}_{1}$ is $\mathrm{o}$, are shown graphically, with a smooth curve passing through them.

It is seen that at the first operation of the equation, as represented by one unit along the time-base, the value of $\mathrm{y}$ is c. After the second operation, $\mathrm{Y}$ has increased by an additional amount $\mathrm{Mc}$, which is less than $\mathrm{C}$ 
bccause $\mathrm{m}$ is less than unity. The third operation adds a further amount $\mathrm{M}^{2} \mathrm{C}$, which is again a proportionate part of the previous increase. After the sixth operation, the total increments which have been added are $\mathrm{C}, \mathrm{MC}, \mathrm{M}^{2} \mathrm{C}, \mathrm{M}^{3} \mathrm{C}, \mathrm{M}^{4} \mathrm{C}$ and $\mathrm{M}^{5} \mathrm{C}$, each of these being equal to $\mathrm{M}$ times the previous increment. Clearly, therefore, the continuous operation of the equation is bringing the value of $\mathrm{y}$ nearer and nearer to a limiting value by permitting an increase in $\mathrm{Y}$ which is always $\mathrm{M}$ times the previous

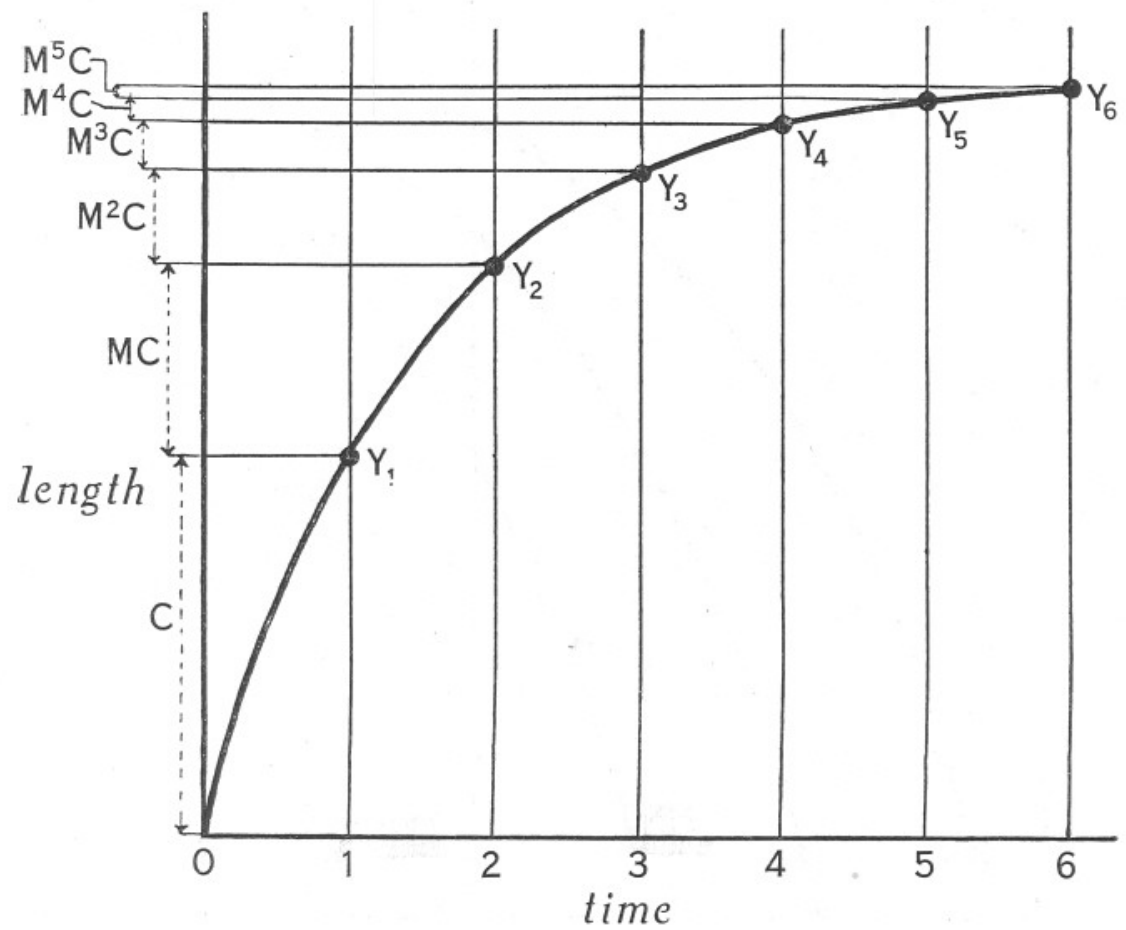

FIG. 3.-For explanation, see Text, p. 330.

increase. It is simple to ascertain what the limiting value actually is, by observing that $\mathrm{Y}_{\mathrm{n}}=\frac{\mathrm{C}\left(1-\mathrm{M}^{\mathrm{n}}\right)}{1-\mathrm{M}}$. As $\mathrm{n}$ is increased, $\mathrm{M}^{\mathrm{n}}$ decreases, so that ultimately $\mathrm{M}_{\mathrm{n}}$ becomes zero, and hence the limiting value $\mathrm{Y}_{x}=\frac{\mathrm{C}}{1-\mathrm{M}}$.

In Fig. 4, on p. 332, the curve given in Fig. 3 has been re-drawn in triplicate from three points along the time-base. It is seen that on the ordinate at time 5, $\mathrm{BA}>\mathrm{CB}>\mathrm{DC}$. This is clearly a repetition of Hodgson's result and, like his, is entirely due to the fact that the three curves occupy different positions in relation to the time-axis. But in Fig. 4, the actual "form" of the curve is known, whereas in Hodgson's figure it is not. 
Attention is now directed to Fig. 5, which resembles Hodgson's figure in that three curves commence from different points along a time-base and intersect the ordinates $\mathrm{XY}$ and $\mathrm{OP}$. Here again, $\mathrm{Fe}>\mathrm{Gd}>\mathrm{Hc}$, but for a different reason. Whereas in Hodgson's figure and also in Fig. 4, a single curve is drawn in three alternative positions, in Fig. 5 the three curves are all different. Curve 1 is that resulting from the continuous operation of the equation $\mathrm{Y}=\cdot 5 \mathrm{x}+15$; curve 2 , from the equation $\mathrm{x}=$

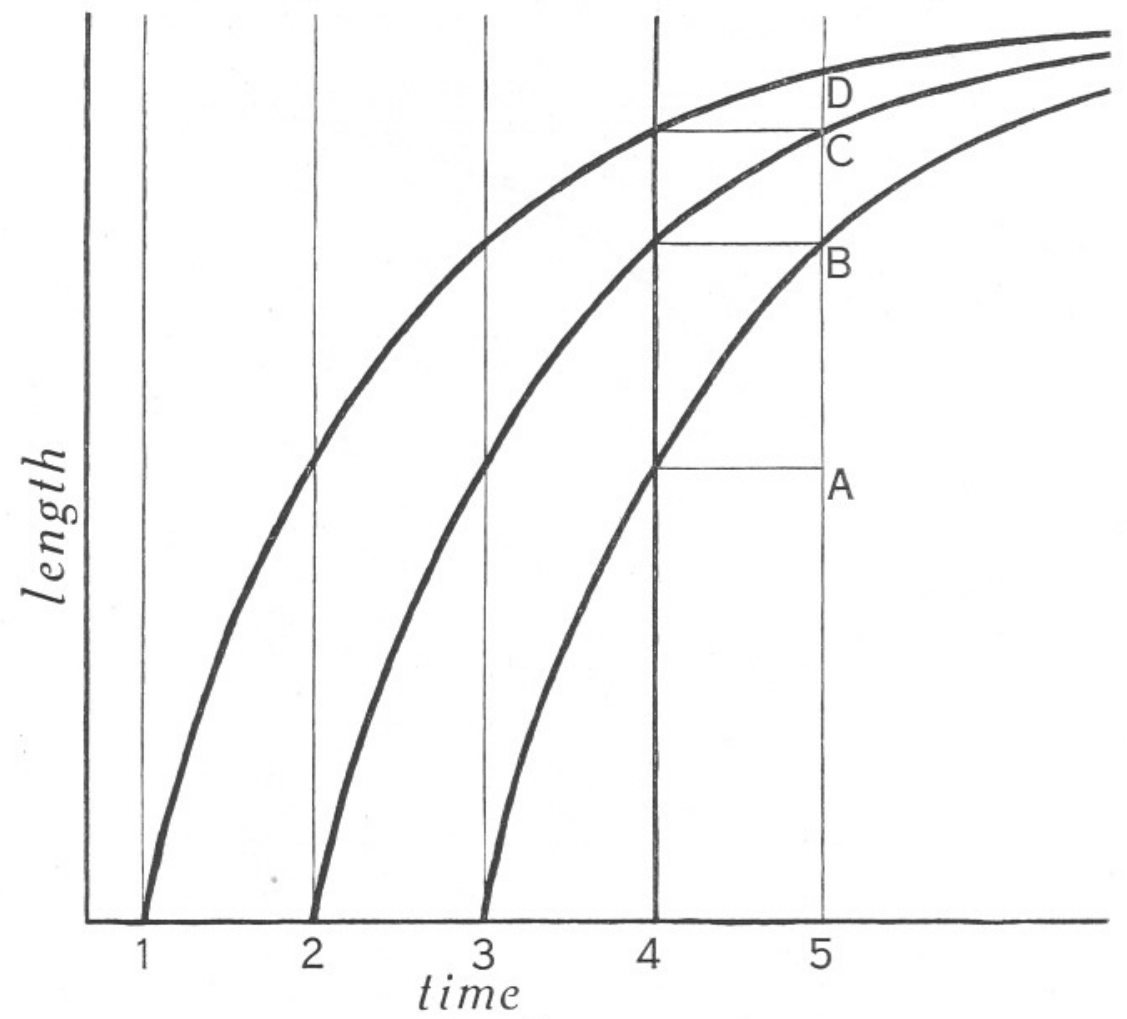

FIG. 4.

$\cdot 6 \mathrm{x}+12$; and curve 3 from the equation $\mathrm{y}=\cdot 7 \mathrm{x}+9$. All three curves are gradually approaching the limiting value of $\frac{\mathrm{C}}{1-\mathrm{M}}$, which in each case is 30 .

In consequence of the order in which the curves are placed with regard to time, they can be extended indefinitely to the right without ever meeting. Wherever the ordinate op is erected, Fe will always be greater than $\mathrm{Gd}$, and $\mathrm{Gd}$ greater than Hc. But the amount by which these increments will differ will depend not only upon the length of time the curves have been extended from their commencement, but also upon their "forms." 
These theoretical considerations show that Hodgson's explanation of " compensatory growth" in the herring is subject to reservation. He says: "If we call the curve AB, the curve of ability to grow, we see that with increase of age there is less ability to increase length and consequently the larger and older fish of any given growth period will grow less than the smaller and younger fish." But it is necessary to add that the

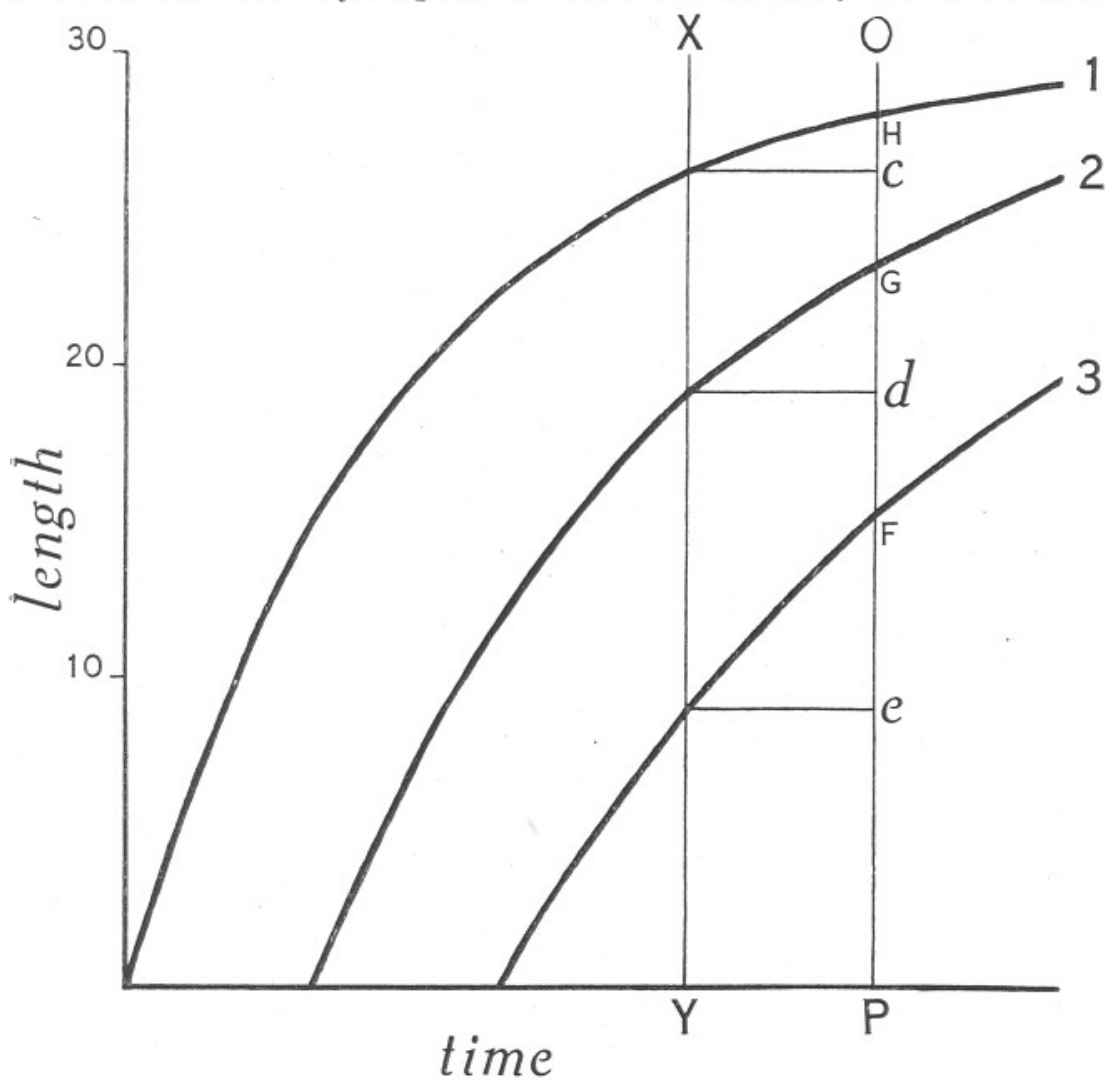

FIG. 5.-For explanation, see Text, p. 332.

" curve of ability to grow" may itself be subject to variation from fish to fish, with important consequences.

Growth in Length in different Geographical Areas.

In earlier papers an endeavour was made to show that regression equations can be used as a technique for the comparison of growth in length in different geographical areas. The method has since been developed with rather instructive results. In illustration, data given by Gilson (21, p. 50, in Table XIII) regarding the mean lengths from $l_{1}$ to $\mathrm{l}_{9}$ for spent herrings taken from the region Griz-Nez to Ostende will now 
be used. Take the equation $\mathrm{Y}=\cdot 56 \mathrm{X}+11.5$ and substitute Gilson's $\mathrm{l}_{\mathrm{I}}$ of $9.96 \mathrm{~cm}$. for $X$. The value of $Y$ (representing $l_{2}$ ) is given by $\cdot 56(9 \cdot 96)+$ $11 \cdot 5=17.08 \mathrm{~cm}$. as against the observed value of $17 \cdot 19 \mathrm{~cm}$. Next, using the value 17.08 as a new value of $\mathrm{X}$, a new value of $\mathrm{Y}$ (this time representing $\left.l_{3}\right)$ is given by $\cdot 56(17 \cdot 08)+11 \cdot 5=21 \cdot 06 \mathrm{~cm}$., as compared with the actual $\mathrm{l}_{3}$ of $21.05 \mathrm{~cm}$. Similarly, the substitution of 21.06 for $\mathrm{X}$ will provide a value of $\mathrm{Y}$ which represents $\mathrm{l}_{4}$. Working in this way, a complete alternative set of calculated values for $l_{2}, l_{3} \ldots l_{9}$ can be obtained and compared with Gilson's data :-

$\begin{array}{lccccccccc} & \mathrm{l}_{1} & \mathrm{l}_{2} & \mathrm{l}_{3} & \mathrm{l}_{4} & \mathrm{l}_{5} & \mathrm{l}_{6} & \mathrm{l}_{7} & \mathrm{l}_{8} & \mathrm{l}_{9} \\ \text { Gilson's means } & 9 \cdot 96 & 17 \cdot 19 & 21 \cdot 05 & 23 \cdot 14 & 24 \cdot 29 & 25 \cdot 20 & 25 \cdot 58 & 26 \cdot 00 & 26 \cdot 50 \\ \text { By equation } & 9 \cdot 96 & 17 \cdot 08 & 21 \cdot 06 & 23 \cdot 29 & 24 \cdot 54 & 25 \cdot 24 & 25 \cdot 64 & 25 \cdot 86 & 25 \cdot 98\end{array}$

It is seen that with the exception of the period from $l_{8}$ to $l_{9}$ the equation. has given values which closely approximate to the observed data. That is to say the herrings represented by Gilson's data had, on average, added to their length yearly in a regular manner, whereby the increment of length added in each succeeding year was approximately $\cdot 56$ times the increment added in the previous year.

The single equation $\mathrm{Y}=.56 \mathrm{X}+11.5$ is thus all that is necessary for determining how the Belgian fish add to their length from year to year. It is especially convenient as a means for comparing the Belgian results with those from other places where the average $l_{1}$ may be higher or lower than $9.96 \mathrm{~cm}$. For instance, Gilson gives Hodgson's data for herrings of the southern North Sea $\left(\mathrm{l}_{1}=8 \mathrm{~cm}\right.$.), and also those of le Gall's Type côtier $\left(\mathrm{l}_{1}=11.88 \mathrm{~cm}\right.$.) and Type atlantique $\left(\mathrm{l}_{1}=12.49 \mathrm{~cm}\right.$.) from the English Channel. By determining the values of $\mathrm{Y}$ when $\mathrm{X}$ is $8,11.88$ and $12 \cdot 49$ respectively, using the Belgian equation, and comparing them with Hodgson's and le Gall's $l_{2}$ values, any difference in growth is at once revealed. In the following table Hodgson's and le Gall's data are fully compared with those given by continuous operation of the Belgian equation :-

$\begin{array}{lc}\begin{array}{c}\text { Southern } \\ \text { (Hodgson.) }\end{array} & \begin{array}{c}\text { North Sea. } \\ \text { Equation. }\end{array} \\ \mathrm{l}_{1}=8 & 8 \cdot 0 \\ \mathrm{l}_{2}=16 & 16 \cdot 0 \\ \mathrm{l}_{3}=20-21 & 20 \cdot 45 \\ \mathrm{l}_{4}=23 & 22 \cdot 95\end{array}$

$\begin{array}{cc}\begin{array}{c}\text { Type Côtier. } \\ \text { (le Gall.) }\end{array} & \text { Equation. } \\ \mathrm{l}_{1}=11 \cdot 88 & 11 \cdot 88 \\ l_{2}=18 \cdot 46 & 18 \cdot 15 \\ l_{3}=21 \cdot 72 & 21 \cdot 66 \\ l_{4}=23 \cdot 30 & 23 \cdot 62 \\ l_{5}=24 \cdot 50 & 24 \cdot 72 \\ l_{6}=25 \cdot 54 & 25 \cdot 34 \\ l_{7}=26 \cdot 40 & 25 \cdot 69\end{array}$

\begin{tabular}{cc}
\multicolumn{2}{c}{ Type Atlantique. } \\
(le Gall.) & Equation. \\
$l_{1}=12 \cdot 49$ & $12 \cdot 49$ \\
$l_{2}=19 \cdot 19$ & $18 \cdot 49$ \\
$l_{3}=22 \cdot 46$ & $21 \cdot 85$ \\
$l_{4}=24 \cdot 25$ & $23 \cdot 74$ \\
$l_{5}=25 \cdot 40$ & $24 \cdot 79$ \\
$l_{6}=26 \cdot 17$ & $25 \cdot 38$ \\
$l_{7}=26 \cdot 94$ & $25: 72$
\end{tabular}

It is seen that Hodgson's data as a whole and le Gall's data for the Type côtier as far as $\mathrm{l}_{6}$ are well fitted by the Belgian equation. The only important difference between the fishes in the three cases is in the value. 
of $l_{1}$. On the other hand, the rate of increase in length of le Gall's Type atlantique is distinctly faster than that given by the Belgian equation.

Good material for a second illustration is provided by a sample of Icelandic herrings of the year-class 1906, taken $3 \mathrm{~km}$. N. of Siglunaes on July 25th, 1908. Data are given by Hjort (23, p. 119, Collection 16). The mean values of $l_{1}$ to $l_{12}$ as recorded by $H$ jort, and the corresponding

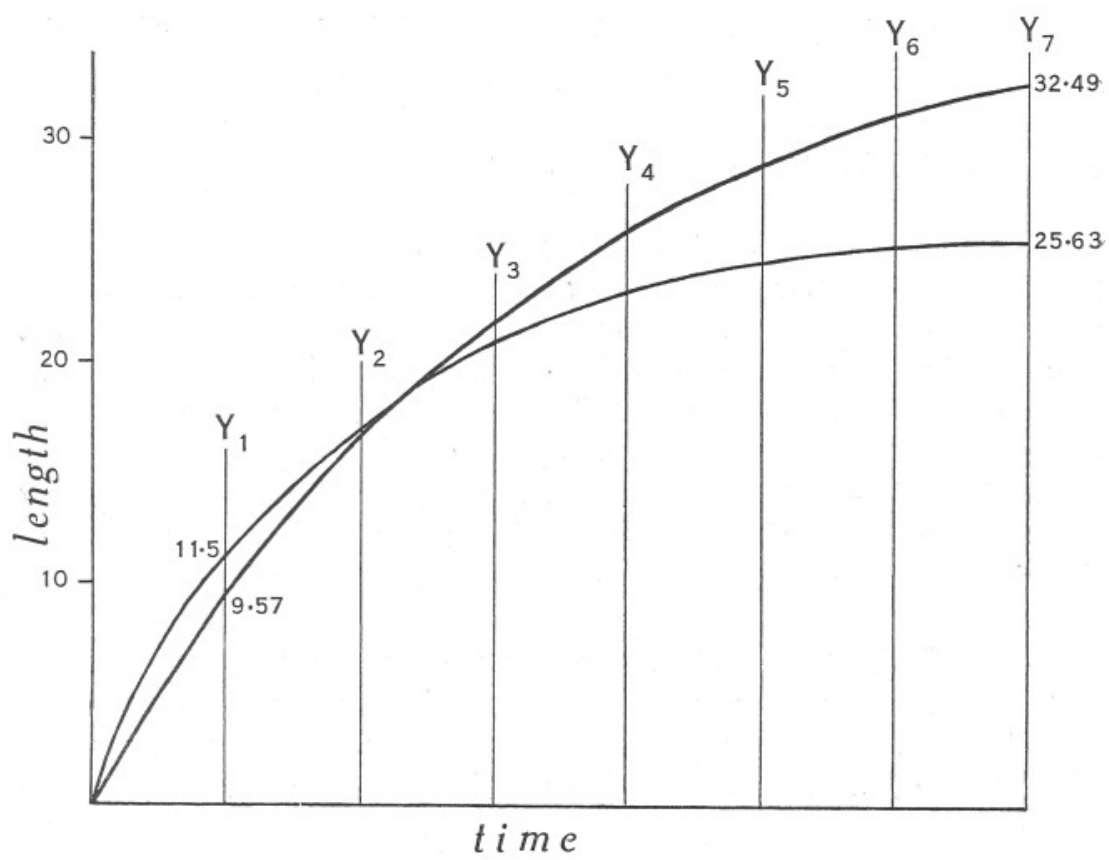

FIG. 6.-Comparison of growth in southern North Sea with that in Iceland.

values calculated from the continuous operation of the equation $\mathrm{Y}=$ $\cdot 742 \mathrm{X}+9 \cdot 57$ are given below :-

$\begin{array}{lcccccccccccc} & \mathrm{l}_{1} & \mathrm{l}_{2} & \mathrm{l}_{3} & \mathrm{l}_{4} & \mathrm{l}_{5} & \mathrm{l}_{6} & \mathrm{l}_{7} & \mathrm{l}_{8} & \mathrm{l}_{9} & \mathrm{l}_{10} & \mathrm{l}_{11} & \mathrm{l}_{12} \\ \text { Hjort } & 8 \cdot 7 & 15 \cdot 7 & 21 \cdot 4 & 26 \cdot 0 & 29 \cdot 0 & 30 \cdot 8 & 32 \cdot 2 & 33 \cdot 2 & 34 \cdot 2 & 35 \cdot 0 & 35 \cdot 8 & 36 \cdot 3 \\ \text { Equation } & 8 \cdot 7 & 16 \cdot 0 & 21 \cdot 5 & \mathbf{2 5 \cdot 5} & 28 \cdot 6 & 30 \cdot 8 & 32 \cdot 4 & 33 \cdot 6 & 34 \cdot 5 & 35 \cdot 2 & 35 \cdot 7 & 36 \cdot 1\end{array}$

Here again a single equation has yielded a close approximation to observed data. But this equation is not the same as the one which satisfied Gilson's, Hodgson's and le Gall's data. The difference between them may be demonstrated by continuously operating both from a commencing value $\mathrm{X}=0$. In effect this is equivalent to starting two curves from the same point in time, as in Fig. 6. The degree to which 
the curves diverge is a measure of the difference in the rate which at length is added. The results are as follows :-

\begin{tabular}{|c|c|c|c|c|c|c|c|c|}
\hline tion. & $Y_{0}$ & $\mathrm{Y}_{1}$ & $\mathrm{Y}_{2}$ & $\mathrm{Y}_{3}$ & $\mathrm{Y}_{4}$ & $\mathrm{Y}_{5}$ & $\mathrm{Y}_{6}$ & $\mathrm{Y}_{7}$ \\
\hline$\tau=.56 \mathrm{X}+11 \cdot 50$ & 0 & $\begin{array}{r}9 \cdot 57 \\
11 \cdot 50\end{array}$ & $\begin{array}{l}16 \cdot 67 \\
16 \cdot 94\end{array}$ & $\begin{array}{l}21 \cdot 94 \\
20 \cdot 98\end{array}$ & $\begin{array}{l}25 \cdot 85 \\
23 \cdot 25\end{array}$ & $\begin{array}{l}28 \cdot 75 \\
24 \cdot 52\end{array}$ & $\begin{array}{l}30 \cdot 90 \\
25 \cdot 23\end{array}$ & $32 \cdot 49$ \\
\hline
\end{tabular}

The Icelandic growth is clearly of a totally different order from that of the southern North Sea and English Channel, both in the successive yearly increments and the limiting value towards which the total length tends to approach each year. The Icelandic limit $\frac{\mathrm{C}}{1-\mathrm{M}}$ is $\frac{9 \cdot 57}{1-.742}=37 \cdot 1 \mathrm{~cm}$, whereas the southern North Sea limit is $\frac{11 \cdot 5}{1-.56}=26 \cdot 1 \mathrm{~cm}$.

The above examples indicate (1) that in many cases the successive yearly increments which a herring adds to its length decrease in magnitude in something very nearly approaching geometric progression, and (2) that there are real differences in growth between herrings of different geographical areas. The first of these points is hardly what might be expected at first sight. And yet, when it is seen how closely the Icelandic data are matched by the equation values over a period of twelve years, it is impossible to ignore the observation. The result would seem to suggest that the Icelandic fish had succeeded in growing, as it were, " according to plan," whereby each succeeding year an increment of length is to be added which shall always be about $\cdot 742$ times the increment added the year before. Returning to the original data and noting the actual annual increments, it is possible to determine how much they deviate from those which would have been added if growth had been strictly according to "plan":-

$\begin{array}{ccc}\text { Actual Increments. } & \begin{array}{c}\text { Increments given by } \\ \text { Growth-Equation. }\end{array} & \text { Difference. } \\ \mathrm{t}_{2}=\mathrm{l}_{2}-\mathrm{l}_{1}=7 \cdot 0 \mathrm{~cm} . & 7 \cdot 3 \mathrm{~cm} . & \cdot 3 \mathrm{~cm} . \\ \mathrm{t}_{3}=\mathrm{l}_{3}-\mathrm{l}_{2}=5 \cdot 7 & 5 \cdot 5 & \cdot 2 \\ \mathrm{t}_{4}=\mathrm{l}_{4}-\mathrm{l}_{3}=4 \cdot 6 & 4 \cdot 0 & \cdot 6 \\ \mathrm{t}_{5}=\mathrm{l}_{5}-\mathrm{l}_{4}=3 \cdot 0 & 3 \cdot 1 & \cdot 1 \\ \mathrm{t}_{6}=\mathrm{l}_{6}-\mathrm{l}_{5}=1 \cdot 8 & 2 \cdot 2 & \cdot 4 \\ \mathrm{t}_{7}=\mathrm{l}_{7}-\mathrm{l}_{6}=1 \cdot 4 & 1 \cdot 6 & \cdot 2 \\ \mathrm{t}_{8}=\mathrm{l}_{8}-\mathrm{l}_{7}=1 \cdot 0 & 1 \cdot 2 & \cdot 2 \\ \mathrm{t}_{9}=\mathrm{l}_{9}-\mathrm{l}_{8}=1 \cdot 0 & \cdot 9 & \cdot 1 \\ \mathrm{t}_{10}=\mathrm{l}_{10}-1_{9}=\cdot 8 & \cdot 7 & \cdot 1 \\ \mathrm{t}_{11}=\mathrm{l}_{11}-1_{10}=\cdot 8 & \cdot 5 & \cdot 3 \\ \mathrm{t}_{12}=\mathrm{l}_{12}-\mathrm{l}_{11}=\cdot 5 & \cdot 4 & \cdot 1\end{array}$

The difference, sometimes positive and sometimes negative, is not very large when expressed in absolute lengths as above, and therefore gives the impression that growth follows the geometric law with consistent regularity, leaving but little evidence of any variation resulting from annual differences in conditions for growth. Some light is thrown on this 
matter, however, if the proportion between a given increment and the preceding one is compared with the theoretically fixed value of $\cdot 742$ :-

$$
\begin{aligned}
& \text { Ratio: } \frac{t_{1+1}}{t_{11}} \\
& \frac{\mathrm{t}_{3}}{\mathrm{t}_{2}}=\frac{5 \cdot 7}{7 \cdot 0}=.81 \\
& \frac{\mathrm{t}_{4}}{\mathrm{t}_{3}}=\frac{4 \cdot 6}{5 \cdot 7}=.81 \\
& \frac{\mathrm{t}_{5}}{\mathrm{t}_{4}}=\frac{3 \cdot 0}{4 \cdot 6}=.65 \\
& \frac{\mathrm{t}_{6}}{\mathrm{t}_{5}}=\frac{1 \cdot 8}{3 \cdot 0}=\cdot 60 \\
& \stackrel{t_{7}}{t_{6}}=\frac{1.4}{1.8}=.78 \\
& t_{8}=\frac{1.0}{1 \cdot t}=.71 \\
& \overline{\mathrm{t}}_{7}=\overline{1 \cdot 4}=\cdot 71 \\
& \frac{t_{9}}{t_{8}}=\frac{1 \cdot 0}{1 \cdot 0}=1.00 \\
& \frac{t_{10}}{t_{9}}=\frac{\cdot 8}{1 \cdot 0}=-80 \\
& \frac{\mathrm{t}_{11}}{\mathrm{t}_{10}}=\frac{\cdot 8}{\cdot \bar{\gamma}}=1.00 \\
& \begin{array}{l}
t_{10} \\
t_{12} \\
t_{11}
\end{array}=\frac{.5}{.8}=.625
\end{aligned}
$$

The values of the ratio $\left(\frac{t_{n+1}}{t_{n}}\right)$ vary between the limits of $\cdot 6$ and $1 \cdot 0$, thus causing the length $l_{n}$ to be sometimes greater and sometimes less than the value which would be attained if the ratio had remained steady at .742. These annual fluctuations in growth rate are not very large when expressed in absolute units in length, particularly in the later years of life. Nevertheless, they must be regarded as real differences due to annual changes in conditions for growth. The geometric law making the best fit to the observed results may be regarded as the smoothing out of real fluctuations which are likely to recur year after year. Viewed in this light there should be no occasion for surprise, either that it should be possible to formulate a law fitting growth with the passage of time, or that individual increments of growth should differ from those indicated by that law. If there is anything unexpected in the matter it is that the law arrived at should be of the particular nature indicated above, although even here it is not necessary to insist that herring-growth is strictly of the geometric type whereby annual increments become less and less in constant ratio. Very possibly the total length does not truly approach an asymptotic limit, although its value at each year for many years in succession may for all practical purposes be sufficiently closely portrayed by a mathematical law which does demand an asymptotic limit. 


\section{Practical Application of Technique.}

Using this technique on data given by Hjort (23), comparisons of growth have been made between samples of herrings obtained from various places in the North Sea. The results are shown in Table IX, the appropriate equation, its period of operation and the limiting value set by it, being given in each instance :-

\section{TABLE IX}

\begin{tabular}{|c|c|c|c|c|}
\hline Locality. & $\begin{array}{c}\text { Reference to Sample } \\
\text { (Hjort, 23). }\end{array}$ & $\begin{array}{l}\text { Period of } \\
\text { operation of } \\
\text { equation. }\end{array}$ & Equation. & $\begin{array}{c}\text { Limiting } \\
\text { value. } \\
\text { (cm.) }\end{array}$ \\
\hline westoft & Collection 25 , pp. 147 and 149 & & & \\
\hline & Year-class 1904 & $l_{1}$ to $l_{5}$ & $\mathrm{Y}=\cdot 6 \mathrm{x}+11 \cdot 0$ & $27 \cdot 5$ \\
\hline & Year-class 1902 & $l_{1}$ to $l_{7}$ & $\mathrm{Y}=\cdot 635 \mathrm{x}+10 \cdot 0$ & $27 \cdot 4$ \\
\hline imsby & Collection 26, p. 155 & & & \\
\hline oes & $\begin{array}{r}\text { Year-class } 1904 \\
\text { Collection 21, p. } 136\end{array}$ & $l_{1}$ to $l_{5}$ & $\mathrm{Y}=\cdot 62 \mathrm{x}+10 \cdot 5$ & $27 \cdot 6$ \\
\hline tlands & $\begin{array}{l}\text { Year-class } 1904 \\
\text { Collection 24, pp. 141-144 }\end{array}$ & $l_{1}$ to $l_{4}$ & $\mathrm{Y}=\cdot 6 \mathrm{x}+12 \cdot 6$ & $31 \cdot 5$ \\
\hline & Year-class 1904 & $l_{1}$ to $l_{5}$ & $\mathrm{Y}=\cdot 6 \mathrm{x}+12 \cdot 6$ & $31 \cdot 5$ \\
\hline & Year-class 1903 & $l_{1}$ to $l_{6}$ & $\mathrm{Y}=\cdot 6 \mathrm{x}+12 \cdot 6$ & $31 \cdot 5$ \\
\hline & Year-class 1900 & $l_{1}$ to $l_{8}^{8}$ & $\mathrm{Y}=\cdot 6 \mathrm{x}+12 \cdot 6$ & $31 \cdot 5$ \\
\hline & Year-class 1902 & $l_{1}$ to $l_{7}^{\circ}$ & $\mathrm{Y}=\cdot 62 \mathrm{x}+11 \cdot 8$ & $33 \cdot 1$ \\
\hline eland & Collection 15, p. 111 & & & \\
\hline & $\begin{array}{r}\text { Year-class } 1895 \\
\text { Collection } 16, \text { p. } 119\end{array}$ & $l_{1}$ to $l_{13}$ & $y=\cdot 74 x+9 \cdot 5$ & $36 \cdot 5$ \\
\hline & Year-class 1896 & $l_{1}$ to $l_{12}$ & $\mathrm{Y}=\cdot 742 \mathrm{x}+9 \cdot 57$ & $37 \cdot 1$ \\
\hline & $\begin{array}{l}\text { Year-class } 1901 \\
\text { Yection } 17, \mathrm{pp} .123 \text { and }\end{array}$ & $l_{1}$ to $l_{8}$ & $\mathrm{Y}=\cdot 74 \mathrm{X}+9 \cdot 8$ & $37 \cdot 7$ \\
\hline & Year-class 1897 & $l_{1}$ to $l_{12}^{8}$ & $y=\cdot 74 x+9 \cdot 4$ & $36 \cdot 2$ \\
\hline
\end{tabular}

It is seen that the limiting value rises from about $27.5 \mathrm{~cm}$. off Lowestoft to $37-38 \mathrm{~cm}$. in Iceland. In the equations there is a marked change in the value of $\mathrm{M}$ and a less pronounced change in $\mathrm{C}$. This alteration in limiting value and form of equation from southward to northward brings to mind the fact that the number of vertebræ shows a similar tendency. (Vide Schnakenbeck 29 and 30 .)

One important matter not taken into account in the results of Table IX is the possibility that individual samples are "mixtures" which ought not to be treated as homogeneous for the study of growth in length. It is emphasized, therefore, that these results are in no sense to be regarded as a critical analysis of the growth in the different regions dealt with. They are merely intended to show the kind of regional differences in growth which are revealed by using growth equations. The samples considered are a selection from Hjort's invaluable data which lend themselves fairly easily to treatment.

\section{"Mixed" Growth.}

Many of Hjort's samples cannot be fitted with a single equation in the manner illustrated in previous pages. Nevertheless it is found that two equations instead of one will satisfy the data. Hjort's Collection 27, 
Year-class 1900, caught off North Shields (Hjort, 23, p. 159), may be used as an initial illustration :-

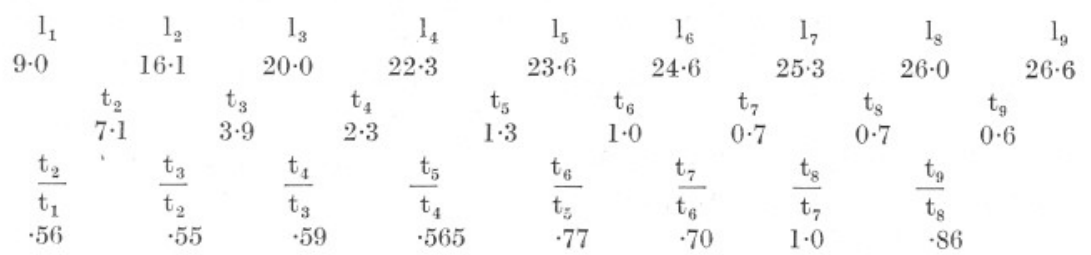

Looking at the values of the ratio $\frac{t_{n+1}}{t_{n}}$, it is seen that up to $1_{5}$ it varies only between .55 and .59 , but that there is then a marked rise to $\cdot 77$. Not at any subsequent time does the ratio fall to the level at which it remained during the earlier years. Using the equation $\mathrm{Y}=\cdot 57 \mathrm{X}+10 \cdot 9$ from a commencing value of $\mathrm{X}=9 \cdot 0$ we get

$\begin{array}{ccccc}l_{1} & l_{2} & l_{3} & l_{4} & l_{5} \\ 9 \cdot 0 & 16 \cdot 0 & 20 \cdot 0 & 22 \cdot 3 & 23 \cdot 6\end{array}$

These values are almost identical with the observed values, and represent growth which is steadily falling off towards an asymptotic limit of $\frac{10 \cdot 9}{.43}=25 \cdot 3 \mathrm{~cm}$. It is obvious, however, that a change occurs at $\mathrm{I}_{5}$. Let us therefore try a second equation, $\mathrm{Y}=\cdot 75 \mathrm{X}+6 \cdot 95$, commencing with $\mathrm{X}=23 \cdot 6$ :-

$\begin{array}{ccccc}l_{5} & 1_{6} & 1_{7} & 1_{8} & 1_{9} \\ 23 \cdot 6 & 24 \cdot 6 & 25 \cdot 4 & 26 \cdot 0 & 26 \cdot 5\end{array}$

These results are a close approximation to the observed values, and represent growth which is steadily falling off towards a limiting value of $\frac{6 \cdot 95}{.25}=27 \cdot 8 \mathrm{~cm}$., as compared with the limit of $25 \cdot 3 \mathrm{~cm}$. towards which the curve of growth up to $l_{5}$ was approaching.

The Norwegian samples provide numerous cases of growth which cannot be fitted by a single growth equation. Hjort's data concerning fishes of year-class 1904 make an instructive study in this connection. In the following table his data of Collection 5 from Leinæs Hammerö (p. 52) and of Collection 9 from $60^{\circ} 30^{\prime}$ N. $3^{\circ} 30^{\prime}$ E. (p. 71) are compared. In the case of the increments $t_{1}, t_{2}$, etc., the year when the increase was made is shown :-

$\begin{array}{cccccccccc} & \mathrm{l}_{1} & \mathrm{l}_{2} & \mathrm{l}_{3} & \mathrm{l}_{4} & \mathrm{l}_{5} & \mathrm{t}_{2} & \mathrm{t}_{3} & \mathrm{t}_{4} & \mathrm{t}_{5} \\ \text { Collection 5 } & 7 \cdot 0 & 11 \cdot 9 & 15 \cdot 4 & 19 \cdot 3 & 22 \cdot 7 & 5 \cdot 0 & 3 \cdot 4 & 3 \cdot 9 & 3 \cdot 4 \\ \text { Collection 5 } & \mathrm{8} \cdot 4 & 15 \cdot 9 & 21 \cdot 9 & 25 \cdot 3 & 27 \cdot 6 & 7 \cdot 5 & 6 \cdot 0 & 3 \cdot 5 & 2 \cdot 2\end{array}$


Consider the two equations beneath in connection with the growth from $l_{1}$ to $l_{3}:-$

(1) $\mathrm{Y}=\cdot 695 \mathrm{x}+7 \cdot 1 \quad$ and (2) $\mathrm{Y}=\cdot 80 \mathrm{x}+9 \cdot 18$

The limiting value for (1) is given by $\frac{7 \cdot 1}{\cdot 305}=23 \cdot 3 \mathrm{~cm}$.

The limiting value for (2) is given by $\frac{9 \cdot 18}{\cdot 20}=45 \cdot 9 \mathrm{~cm}$.

Applying equation (1) for a commencing value of $7 \cdot 0 \mathrm{~cm}$. and equation (2) for a commencing value of $8.4 \mathrm{~cm}$. we get

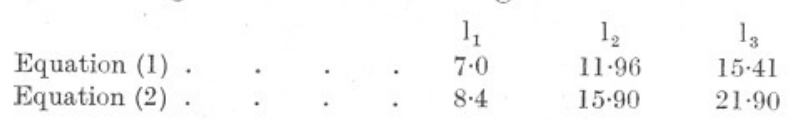

Comparing these results with Hjort's data it is seen that equation (1) reproduces the values for Collection 5 and equation (2) those for Collection 9. Thus the growth of the fishes of Collection 5 during the years 1905 and 1906 was quite different from the growth of the fishes of Collection 9 during the same two years.

Next, consider two further equations in connection with the growth . from $l_{3}$ to $l_{5}$ :-

(3) $\mathrm{Y}=\cdot 87 \mathrm{x}+5 \cdot 9$ and $(4) \quad \mathrm{Y}=\cdot 615 \mathrm{x}+11 \cdot 9$

The limiting values are :-

$$
\begin{aligned}
& \text { for }(3) \ldots \frac{5 \cdot 9}{13}=45 \cdot 4 \mathrm{~cm} . \\
& \text { for }(4) \ldots \frac{11 \cdot 9}{385}=30 \cdot 9 \mathrm{~cm} .
\end{aligned}
$$

Applying equation (3) for a commencing value of $15 \cdot 41$, and equation (4) for a commencing value of $21 \cdot 90$, the following values are obtained :-

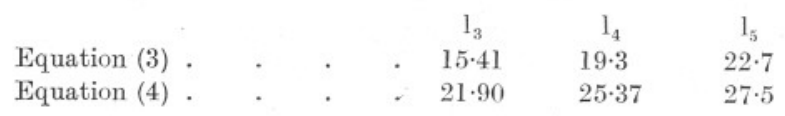

That is to say the growth of the fishes of Collection 5 from $l_{3}$ to $l_{5}$ is reproduced by equation (3), and that of the fishes of Collection 7 by equation (4). Hence in 1907 and 1908, as well as in 1905 and 1906, the growth was different for the two collections.

Summarising, it is now seen that Collection 5 shows a growth from $l_{1}$ to $l_{3}$ towards a limit of about $23 \mathrm{~cm}$., followed by a growth from $l_{3}$ to $l_{5}$ towards the much higher limit of about $45 \mathrm{~cm}$. The change in growth rate results in the increment $t_{4}$ added during 1907 being greater than $t_{3}$ laid down in 1906. In contrast, Collection 9 shows a growth from $\mathrm{l}_{1}$ to $\mathrm{l}_{3}$ towards a high limit of approximately $46 \mathrm{~cm}$., followed by a growth from $I_{3}$ to $l_{5}$ towards a much lower limit of about $32 \mathrm{~cm}$. The change in growth rate at $l_{3}$, however, is not so self-evident as in Collection 5 (where the dominance of $t_{4}$ over $t_{3}$ is visible) and only becomes apparent when growth is analysed. 
How are these results to be interpreted ? A reasonable answer to this question is twofold in nature :-

(a) That the fishes of Collection 5 were under quite different conditions for growth during 1905 and 1906 from those under which the fishes of Collection 9 were growing during the same period. Similarly during 1907 and 1908.

(b) That the fishes of the same Collection, whether 5 or 9 , were not under the same conditions for growth during 1905 and 1906 as they were during 1907 and 1908.

\section{Growth in Length as Evidence of Migration.}

If the conclusions $(a)$ and $(b)$ just given are substantially correct, it seems to follow that the growth characters revealed by the study of scale-measurements can be used as clues to herring migrations. This point has been strongly advocated by Lea (2y). The Norwegian investigator contends that the history of growth of the different year-classes occurring in a catch may exhibit certain extremely characteristic and striking peculiarities which, precisely because they deviate from the normal, may very easily be observed and recognised. He has no hesitation, therefore, in asserting that Norwegian herrings occurred in the spawning condition off the Faeroes in 1910, intermixed with non-Norwegian (Faeroese) herrings, and also suggests that spring-spawning herrings taken off the Shetlands in March-April, 1923, were also Norwegian fish, especially of the year-class 1918. He also shows how the fish caught in the Skagerak by Swedish and Norwegian vessels fishing independently agreed in growth characters not only with one another but with those from shoals met with at the west coast of Norway a little south of Cape Stadt. All belonged to shoals or groups of immature Norwegian herring. Thus Lea arrives at the conclusion that ". . . it is possible to identify or recognise Norwegian herring even if they occur in localities where one would not have expected them." The investigations of Storrow (32) also, in distinguishing between growth in "narrow seas" and that under "oceanic" conditions, follow very similar lines as regards their underlying principle. All that is claimed for the method of calculating growth equations in this type of investigation is that it provides a convenient and practical technique of growthanalysis which will readily reveal the characteristics of growth in different places, and facilitate the carrying out of growth-comparisons. While Lea and Storrow would be directly influenced in their judgment by the absolute size of the increments added to its length by a fish during a period of time, the investigator using the equations would review the same basic facts, but in terms of the growth-equations reproducing the increments, rather than of the increments themselves. As with any other method which seeks to trace the migrations of herrings by indirect means, 
however, one needs to consider when the technique can be legitimately applied and how the results of its use must be interpreted.

\section{The Plymouth Shoals.}

In this discussion on growth in length we have been drawn away from the situation at Plymouth. Growth studies of the herrings visiting Plymouth waters have shown that the shoals are " mixed " in a complex manner as regards growth in length. It is impossible to give a single equation which, by continuous operation, will give successive values $l_{2}, l_{3}$, etc., that may be considered as a "type " of growth representative of the Plymouth fish. There is no such "type." On the other hand, it has previously been suggested (Ford, 9, p. 299) that if the spawning shoals visiting Plymouth are assumed to have come partly from the more enclosed waters of the English Channel and partly from the more open waters at the Atlantic end of the Channel (conditions for growth in these two areas being different), the complex growth-data can be interpreted in terms of migratory changes.

It has already been demonstrated (p. 334) that at the extreme eastern end of the Channel and the Southern Bight, growth is not greatly different from that reproduced by the equation $\mathrm{Y}=\cdot 56 \mathrm{x}+11 \cdot 5$. It has also been shown (Ford, 12) that fishes caught off the Sussex coast, as well as those which Hodgson terms his "Channel type," differ from the above only in the length $l_{1}$, growth being otherwise of a similar order. Coming westward to Portland and Plymouth, le Gall (18, p. 47) gives data concerning samples taken from catches off Brixham in Portland Bay, and in the bay of Plymouth :-

\begin{tabular}{|c|c|c|c|c|c|c|c|c|}
\hline & & $l_{1}$ & $l_{2}$ & $\mathrm{l}_{3}$ & $I_{4}$ & $1_{5}$ & $I_{6}$ & $1_{7}$ \\
\hline B & . & $12 \cdot 20$ & $18 \cdot 30$ & $21 \cdot 00$ & & & & \\
\hline Plymouth & . & $11 \cdot 88$ & $18 \cdot 46$ & $21 \cdot 72$ & $23 \cdot 30$ & $24 \cdot 50$ & $25 \cdot 54$ & $26 \cdot 40$ \\
\hline
\end{tabular}

The Brixham sample is satisfactorily fitted by the equation $\mathrm{Y}=\cdot 56 \mathrm{x}$ +11.5 and the Plymouth data, which Gilson refers to as le Gall's " type côtier," have already been shown (p. 334) to be in accordance with this same equation. That is to say, samples at Brixham and Plymouth, examined by le Gall, have been found which show growth of the same character as that of fishes from the Southern Bight and eastern English Channel. But le Gall in the same paper also gives data from the coast of Brittany :-

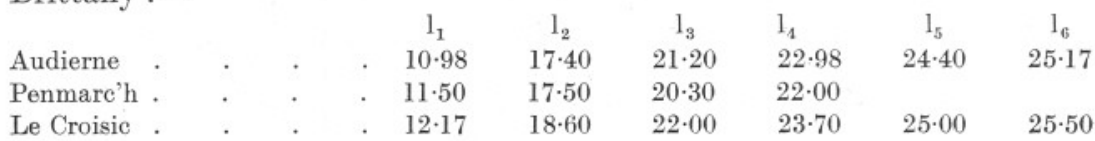

Of these it can be said that the samples from Audierne and le Croisic are reasonably well fitted by the equation used above, and even those from 
Penmarc'h are not greatly different. From the Southern Bight to Brittany, therefore, herrings have been taken which have all grown according to one and the same growth curve, although differing in the length $l_{1}$.

But while this is true, it must be observed that not all the herrings in the Plymouth area have growth-characters which are fitted by the equation $\mathrm{y}=\cdot 56 \mathrm{x}+11 \cdot 5$. Thus, it was shown above on $\mathrm{p} .334$ that herrings caught in the Bay of Plymouth by le Gall and called by him the "type atlantique" do not conform to the equation. Nor will all the data collected at the Plymouth laboratory be thus satisfied. On the contrary, it becomes necessary to utilise fresh equations which give a higher limiting value than that imposed by the equation $\mathrm{y}=556 \mathrm{x}+11 \cdot 5$. In this connection, it is of interest to refer to data brought together by Watkin (48) and referring to herrings taken in south-western waters. In his Table XX, on p. 87, Watkin records the average size at the formation of each winter ring for $(a)$ drift herrings caught mainly in statistical region VIIg off the south-west coasts of Great Britain, $(b)$ trawled herrings of the "Smalls," and (c) drift herrings taken at Plymouth and examined by Ford (9, p. 295) :-

$\begin{array}{cccccccccc} & \mathrm{l}_{1} & \mathrm{l}_{2} & \mathrm{l}_{3} & \mathrm{l}_{4} & \mathrm{l}_{5} & \mathrm{l}_{6} & \mathrm{l}_{7} & \mathrm{l}_{8} & \mathrm{l}_{9} \\ \text { (a) } & 12 \cdot 6 & 20 \cdot 2 & 24 \cdot 0 & 26 \cdot 2 & 27 \cdot 4 & 28 \cdot 2 & 28 \cdot 8 & 29 \cdot 5 & 29 \cdot 9 \\ \text { (b) } & 15 \cdot 9 & 23 \cdot 6 & 25 \cdot 4 & 27 \cdot 2 & 28 \cdot 0 & 28 \cdot 7 & 29 \cdot 6 & 29 \cdot 8 & 30 \cdot 0 \\ \text { (c) } & 13 \cdot 88 & 21 \cdot 03 & 24 \cdot 64 & 27 \cdot 02 & & & & \end{array}$

Considering $(a)$ above, it has been found that the lengths $l_{1}$ to $l_{5}$ are in accord with the results of the repeated operation of equation $\mathrm{Y}=\cdot 53 \mathrm{x}$ $+13 \cdot 5$, and the lengths $l_{5}$ to $l_{9}$ to a second equation $\mathrm{y}=\cdot 85 \mathrm{x}+4 \cdot 87$. That is to say, the drift fish in region VIIg grow from $l_{1}$ to $l_{5}$ towards an asymptotic limit of $\frac{13.5}{1-.53}=28.7 \mathrm{~cm}$., and from $l_{5}$ to $l_{9}$ towards a higher asymptotic limit of $\frac{4 \cdot 87}{1-\cdot 85}=32.5 \mathrm{~cm}$. The observed values of $l_{5}$ to $l_{9}$ and the values calculated from the two equations are given together below, and it will be seen that they are in close agreement :-

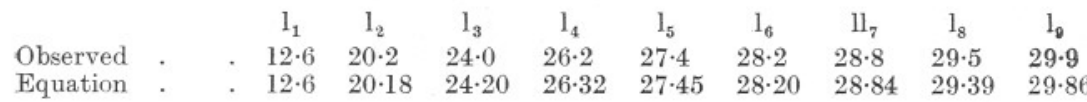

Turning next to the fish from the "Smalls," (b) above, it is found that except for the one period $l_{1}$ to $l_{2}$, the growth corresponds with that of the drift fish from VIIg, in that from $l_{2}$ to $l_{5}$ the equation $\mathrm{x}=\cdot 53 \mathrm{x}+13 \cdot 5$ applies, and from $\mathrm{I}_{5}$ to $\mathrm{l}_{9}$, the equation $\mathrm{Y}=\cdot 85 \mathrm{x}+4 \cdot 87$ :-

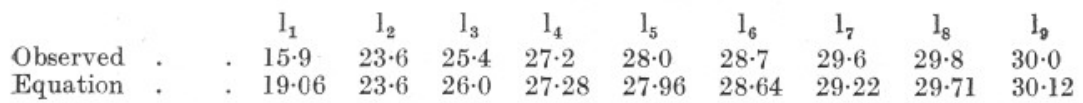


The "Smalls" fish thus differ from the drift fish from VIIg in that they are on an average larger at $l_{1}$ and grow to a greater size at $l_{2}$; subsequently, however, their growth is of a similar order.

The Plymouth data, $(c)$ above, like those of the drift fish from viIg are satisfied by the equation $\mathrm{Y}=\cdot 53 \mathrm{x}+13 \cdot 5$ from $\mathrm{l}_{1}$ to $\mathrm{l}_{3}$ :-

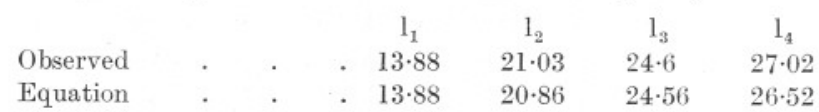

All the foregoing observations have a bearing upon the composition of the herring shoals which come to Plymouth in the winter and spring for spawning. Some of the fish are indistinguishable in growth from fishes taken in the Atlantic fisheries; others resemble fishes taken in the eastern part of the English Channel, while others, again, show a " mixed" growth in the sense that they resemble Atlantic fish at some part of their growth, and the more easterly fish at another. A reasonable interpretation of these variations in growth character is that the Plymouth spawning grounds are visited by shoals coming both from the westward. and the eastward. Those fishes coming from the westward will have fed and grown under Atlantic conditions during the summer preceding spawning, and will have grown more than those of a corresponding size and age which have remained within the more enclosed waters of the Channel. Furthermore, it is necessary to believe that fishes which come from the east or west to spawn do not necessarily return always to the same feeding grounds from which they come. In other words, the study of the growth in length from year to year is an indirect means of determining the nature and extent of the migrations between the Plymouth spawning area and the feeding grounds of the Channel and Atlantic. Concerning these migrations, Matthias Dunn (4) has written :-

" On our coast (Devon and Cornwall), after spawning, Herrings generally take off into deep water, and seldom remain in one locality unless food is plentiful; and, as the summer advances, they generally find themselves far out in the deep waters of the Channel or in the Atlantic. When the autumn arrives . . . they gather themselves in large schools and move landwards to the necessary weedy coral or stony bed wherein to deposit their eggs. . . . One of the largest migrations ever noted on our southern coasts was in the autumn of 1892. Late in October our fishing boats fell in with quantities of Herrings some fifteen miles south of the Eddystone, while fishing for mackerel there, and, although only mackerel nets were at first used, so plentiful were they, that it was. nothing uncommon for boats nightly to catch ten thousand herrings in them. Nothing seemed to disturb them, and, although apparently wandering at leisure, eventually it was found that they gradually but. 
surely kept up a northerly course, and early in December finally reached their spawning grounds on the Devon coast-to the east of Plymouth. . . . This is a sample of how Herrings generally migrate around the coasts; and, probably, the events connected with the migrations of the Herrings in the North Channel (i.e. off north coast of Cornwall) in their various stages, move much on the same lines. For some years past these northern fish have been in greater numbers than the southern schools, and in their spawning migration seem to strike the land somewhere to the north and east of Port Isaac. When their intuitions tell them that the range of ground for spawning purposes is unfit or insufficient for their wants in that immediate neighbourhood, they gradually drop down the coasts, leaving ample numbers to cover grounds near Padstow, Newquay, St. Ives, and Mounts Bay. Moreover, I think there can be no doubt that sometimes they have been in such numbers as to necessitate their moving further along the coast into the English Channel, and to have joined their friends near Plymouth in Bigbury Bay. For many years, off and on, when pilchards are migrating late in November, quantities of herrings will sometimes pass with them; and at other times Herrings will migrate along distinct from the pilchards. We have many times traced these fish from the Lizard to beyond Plymouth."

This scheme of migration, visualised by Dunn, appears to express, as clearly as possible, the general conception arrived at by the comparison of growth-rates among the fishes concerned, and there seems no necessity to suggest any radical alteration in the events described. The only addition considered necessary is that shoals do not always return to the grounds from which they came, with the result that " mixed" growth is a characteristic of the fishes over the whole area of distribution covered by the migratory cycles.

\section{Genotypes in the Herring.}

In foregoing pages, differences in rate of growth in length from one geographical region to another were discussed. Throughout the discussion, however, it was assumed that a "herring" was a " herring," the distinction between phenotype and genotype being ignored. The degree to which the observed variation in growth in length among the Plymouth fishes is genotypic as opposed to phenotypic, that is to say, the degree to which it is due to qualities inherited from the ancestors of the fish as opposed to qualities due directly to the conditions under which the fish has grown up, is a question for future investigation, but much work has already been done in an endeavour to recognise genotypes at Plymouth by analysing counts of the number of vertebræ. Many samples, taken at random from commercial catches, have been examined, and appreciable differences in 
number of vertebræ have been found, but the difficulties in interpreting the differences have been great. The facts as they appear to the writer will now be presented.

\section{Variation in the Number of Vertebra from Sample to Sample.}

Adopting some arbitrary standard of counting, including or excluding the urostyle according to choice, the "number of vertebræ" for each fish in a sample may be determined, and a frequency table prepared which summarises the individual counts. In its simplest form this table will show the number of individuals having $(x),(x+1),(x+2) \ldots$ etc. vertebræ respectively, but it is a simple mathematical operation to reduce the original numbers to a percentage basis, as if the sample really consisted of exactly 100 fishes. The percentage-frequencies may also be presented graphically, plotting the values of $(x),(x+1),(x+2)$. . etc., as abscissæ and the corresponding percentages as ordinates. Alternatively, recognised statistical methods may be followed for the calculation of the "arithmetic mean number of vertebræ" for a sample, together with the "standard deviation" and "standard error."

Whichever way one elects to summarise sample-data, whether as a table of frequencies, a graph of percentage-frequencies, or an arithmetic mean, one is free to make direct comparison between sample and sample and thus to establish the extent of agreement or disagreement. The circumstances governing a particular investigation will, of course, decide which form of summary is the most convenient to adopt for the purpose of comparison. Sample A may be found to differ from sample B by an amount $a$, but the significance of the difference $a$ cannot be accurately assessed without much detailed information concerning the samples themselves.

The samples to be discussed were taken from the regions shown in the chart on p. 307. Details of these samples are to be found in Ford (8), and also in Table XIX at the end of this paper in p. 383, and we shall first consider the total range of variation in number of vertebræ for all the samples examined, irrespective of locality and time of capture, or the length, age and sexual condition of the fishes taken. The individual number of vertebræ varies from $53^{*}$ to $58^{*}$ and the arithmetic mean from $55 \cdot 48 *$ to $55 \cdot 99 *$. Fishes with 55 or 56 vertebræ together account for 78 per cent or more of every sample, while those with 57 vertebræ only rarely exceed 20 per cent. Fishes with 54 vertebræ hardly ever number more than 2 or 3 per 100, while those with 53 or 58 are very uncommon indeed.

* These numbers do not include the urostyle. Throughout this paper, unless otherwise stated, the number of vertebræ, whether individual or as an average, is always exclusive of the urostyle. 
Expressing the percentage frequency of each sample in the form of a graph, it is found that the shape of the graph varies between the extremes shown at the top and bottom of Fig. 7, with intermediates such as those

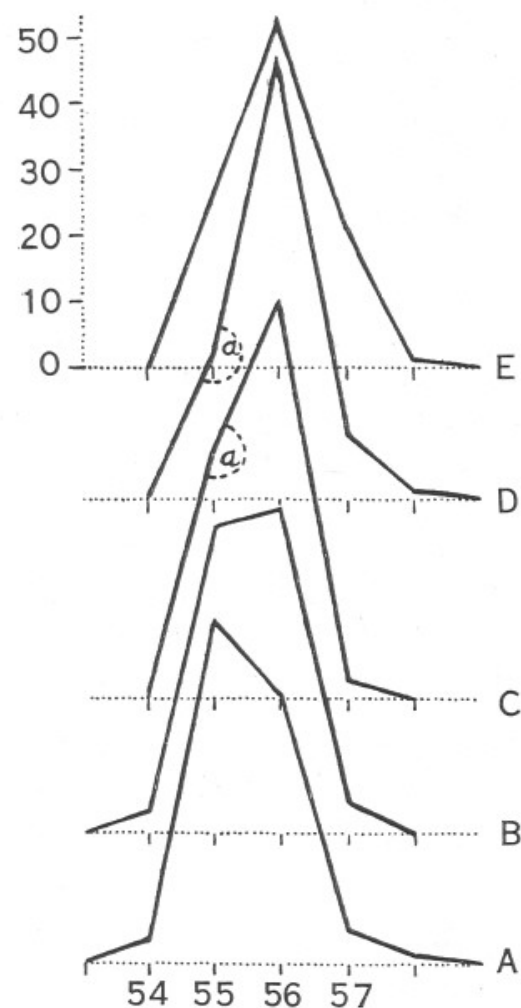

FIG. 7.-Five percentage frequency graphs of the number of vertebræ, representative of the range of variation in form.

A... Sample from statist. region VIIg. July, B... , , Mounts Bay. March,

C..., , Brighton. December, 1926.

D... , , , Plymouth. February,

E... , , , statist. region VIIg. June,

In graph $\mathrm{C}$, the angle $a$ is In graph $\mathrm{D}$, the angle $a$ is more than $180^{\circ}$.
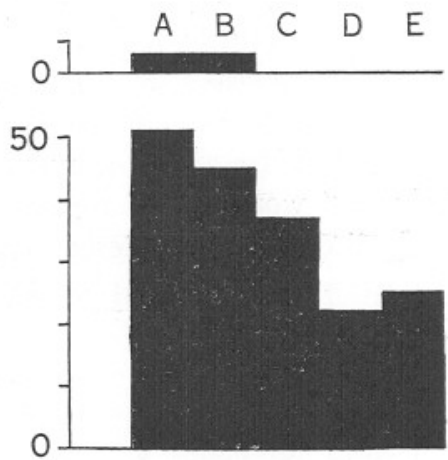

55
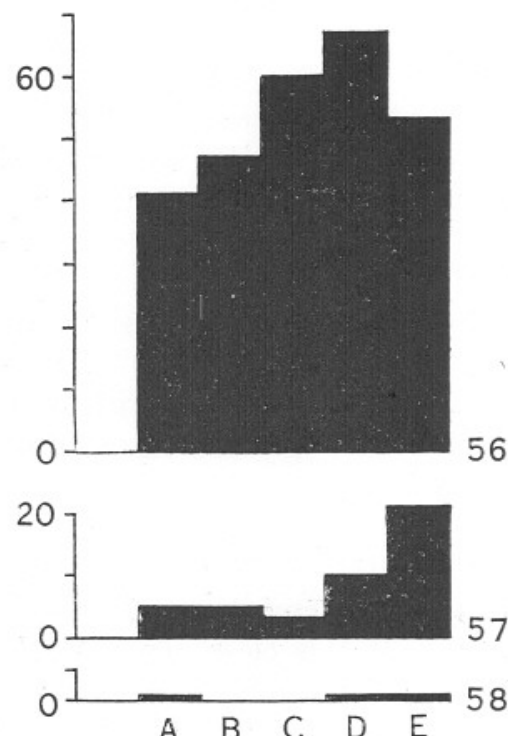

FIG. 8.-Percentage frequency in vertebral number for samples A to E. (See also Fig. 7.)

indicated in the figure. The change in shape of the graph is clearly due to the fact that the percentage of fishes with 55 vertebræ which is so dominant in sample A becomes progressively reduced (see also Fig. 8), 
while the percentage of fishes with 56 vertebræ is increased. The percentage with 57 vertebræ increases from sample A to sample E.

Schnakenbeck (29 and 30) has strongly advocated the extensive use of percentage-frequency graphs of the kind shown in Fig. 7, and it is not denied that a pictorial representation of percentages will conveniently and plainly convey to the mind the composition of a sample with regard to the number of vertebræ. But when graphs of the "single-peaked" type, such as $\mathrm{C}$ and D in Fig. 7, are superimposed one above the other, an artificial "sameness" in appearance is apt to be created which may mask considerable differences in vertebral composition. For detailed comparison of frequency-graphs, therefore, some description criterion of "shape" would seem to be desirable. This is particularly needed when dealing with the present samples, the majority of which give the single-peaked type of graph. The following arbitrary* standards have been adopted :-

Class 1.

Percentage of fishes with 55 vertebræ is greater than that of fishes. with 56 vertebræ. The frequency graph is illustrated by $\mathrm{A}$ in Fig. 7 .

\section{Class 2.}

Percentage of fishes with 56 vertebræ is greater than that of fishes with 55 vertebræ, but the difference does not exceed $10 \%$. The frequency graph is of the "truncated" type illustrated by B in Fig. 7.

\section{Class 3.}

Percentage of fishes with 56 vertebræ exceeds that for fishes with 55 . vertebræ by more than $10 \%$, although it is less than twice the percentage for 55 vertebræ. Fishes with 57 vertebræ account for not more than $13 \%$. Graph $\mathrm{C}$ in Fig. 7 belongs to this class.

\section{Class 4.}

Percentage of fishes with 56 vertebræ is at least twice that for 55 vertebræ. Percentage with 57 vertebræ is not more than $13 \%$. In graphs of this class, represented by D in Fig. 7, the angle $a$ is greater than $180^{\circ}$, whereas in graphs of class 3 , angle $a$ is less than $180^{\circ}$.

\section{Class 5.}

Percentage of fishes with 57 vertebræ is at least 14\%, while the percentages for vertebræ 55 and 56 may agree with those of class 3 or 4 . The frequency graph is typified by $\mathrm{E}$ in Fig. 7.

* It should be understood that the classification is quite arbitrary and artificial, and is used merely as a convenient standard for the purpose in hand. 
The total of 103 samples examined may thus be split up according to the above five classes :-

\begin{tabular}{|c|c|c|}
\hline Class 1 & . & • \\
\hline Class 2 & & . \\
\hline Class 3 & . & . \\
\hline Class 4 & . & . \\
\hline Class 5 & : & \\
\hline
\end{tabular}

It is seen that the bulk of the samples falls into classes 3 and 4, indicating that fishes with 56 vertebræ are usually in decided predominance. But this segregation of samples according to vertebral distribution proves to be a segregation according to the geographical regions in which the samples were taken. This is shown in Table X :-

\section{TABLE X}

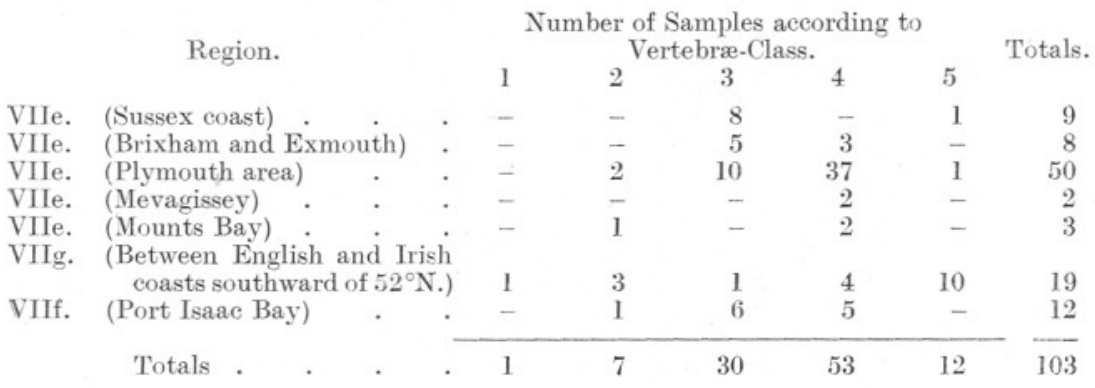

It will be observed from Table $\mathrm{X}$ that the samples from region VIIg and VIIe (Sussex coast) are different both from one another and from those of other areas. Of the 19 samples from VIIg no less than 10 are of class 5 , as against only 2 of this class in the 84 samples taken elsewhere. Furthermore, only 1 of the VIIg samples is of class 3, whereas in VIIe (Sussex coast) 8 out of the total of 9 are of this class. In other words, samples from the Atlantic end of the English Channel (region VIIg) are characterised by a higher number of vertebræ than samples from the eastern end of the Channel (region VIIe, Sussex coast).

The majority of the Plymouth samples fall into class 4 which is intermediate in character between classes 5 and 3 . But, geographically, Plymouth occupies an intermediate position between VIIg and VIIe (Sussex coast). Similarly, the Brixham and Exmouth samples are intermediate between those from Plymouth and Sussex, and so, also, are the geographical positions.

This tendency for the number of vertebræ to rise from east to west in the English Channel has been shown in an earlier paper (Ford, 8) by using the arithmetic means for the samples, instead of the percentagefrequencies. 
Although in region VIIg samples of class 5 are so much in evidence, it is in this same region that samples of classes 1 and 2 are the most common. Hence, in one and the same region, there is wide variation in the number of vertebræ. Although somewhat less pronounced, the range in vertebral variation in the other regions is also considerable. While, therefore, there is a tendency for the number of vertebræ to rise from east to west in the English Channel, there is wide variation between samples. taken in close proximity to one another.

\section{The Conception of "Races" of Herrings.}

Having noted the extent of the differences in number of vertebræ between samples, it is helpful to enquire how such sample differences might conceivably be brought about. It is generally believed that the number of vertebræ, once fixed in the early life of an individual, remains unaltered, so that the difference in vertebral number between samples of fish must be due to the manner in which fish group themselves during the successive phases of their life-history. The shoal, as usually conceived, is a naturally formed group of herrings composed of individuals which differ in age but do not vary greatly in length or swimming capacity. But for how long a given shoal retains its distinctive identity without becoming merged into a greater entity or split up into groups, it is difficult to say. Nor is it easy to determine at what rate the composition of a shoal is changed as the result of the replacement of older members by recruits. Yet such changes might conceivably result in marked changes in vertebral distribution. Consider a spawning shoal arriving at a spawning place. It will show a certain vertebral distribution, and, presumably, will have all its members in approximately the same state of sexual maturity. If that shoal spawned by itself, we should have a parental spawning population of given vertebral distribution giving rise to a new generation. More probably, however, the spawning stock will consist of more than one shoal. Nevertheless, the vertebral distribution of the total spawning population might still remain fixed at a certain value provided that each and every shoal showed the same vertebral distribution. If such were the case, it is logical to think that the shoals which leave after spawning would also be alike in vertebral distribution, even if the retiring shoals were quite different as regards their individual members from those which came to spawn. The conceivable contrast is that of a complex spawning population made up of a number of shoals which differ in vertebral distribution, and of retiring shoals for which the vertebral distribution is different from that of the ones which contributed to the spawning population.

On a feeding ground, as opposed to a spawning ground, the only 
character in common which it is necessary to attach to individual shoals is that all have come to feed. It is of little moment that they may differ in vertebral distribution. But later on, when the call of spawning occasions the concentration of fish prior to a movement inshore to the spawning place, the facts are otherwise. If smaller shoals join forces to form greater ones there arises the possibility of the coming together of "groups " of herrings which have hitherto been distinct in their number of vertebræ, unless there be some inherent character in the fishes which impels them to make a deliberate choice of their associates for spawning. In this event, the period when shoals concentrate for the spawning migration could be regarded as a "sorting-out" time when genotypes come apart.

This brings us face to face with all the problems associated with the hypothesis of " races " in the herring. In his important theses, Schnakenbeck (29 and 30 ) considers the division of the herring species into a number of races which are to be regarded as morphologically and physiologically distinct entities. He suggests that each race is characterised by its number of vertebræ, which can be expressed in the form of a distinctive frequency graph. Members of a race spawn at a given time of year in given places, the continuity of the race from generation to generation being preserved by the strict inheritance of the number of vertebræ and by the fact that no two races spawn on the same ground at the same time.

If the basic premises for this conception of herring races were proven facts, it would be permissible to treat all samples of catches as racesamples, of which some might be homogeneous in race but others mixtures of races. Differences between samples would thus be manifestations of differences in racial composition. Indeed, this has been done already by Schnakenbeck himself who has postulated two distinct races within the geographical area covered by the Plymouth data. He includes all the herrings of the English Channel in one race, "The Channel Sea Herring," but refers those of the Smalls to a second race, designated "The Smalls Herring." Reserving judgment as to the validity of the premises on which Schnakenbeck has established these races, it is instructive to treat the Plymouth samples as if they were race-samples.

\section{The "Channel Sea Herring" and the "Smalls Herring."}

From Schnakenbeck's Fig. 33 (30, p. 516), which is here reproduced as Fig. 9 on p. 352, the form of the frequency graph typifying the number of vertebræ for the two races may be seen. It must be noted, however, that Schnakenbeck's count of the vertebræ is always one vertebra greater than the Plymouth count, since he includes the urostyle. Series A to the left of the figure represents the "Smalls" race, and series B on the right, the. 
"Channel" race. Reference to Schnakenbeck's legend to his Fig. 33 shows that the samples of Series A are actually the class 5 samples from region VIIg already referred to above, while it is evident from the figure itself (reproduced here as Fig. 9) that the Series B are class 3 samples
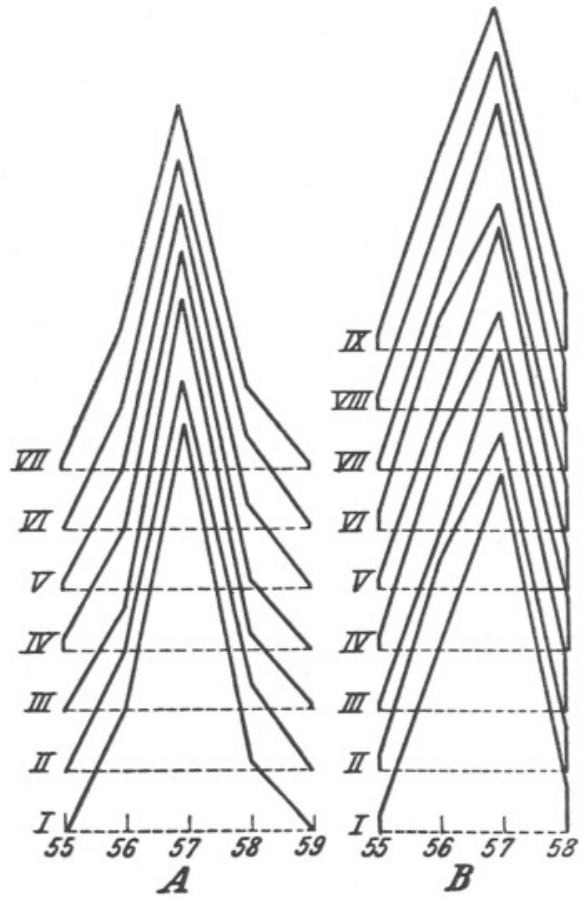

Fig. 9.-Reproduction of Fig. 33 from Schnakenbeck (30).

Series A.... Samples from "Smalls," region VIIg.

Series B.... Samples from Eastern English Channel.

from region VIId and e. The vertebral frequencies which Schnakenbeck uses as types of the races is given in p. 550 of his paper $(\mathbf{3 0})$ :-

\section{Number of Vertebr玉.}

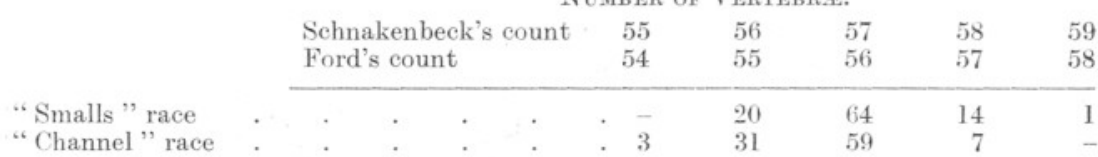

Here again it is seen that the vertebral frequency is of class 5 for the "Smalls" race and class 3 for the "Channel." The difference between these two frequencies and their graphic representation is so pronounced that no one will question their separation, even if doubts are retained as to their racial significance.

But since samples of classes 5 and 3 occur in other regions, it would 
seem necessary to stipulate that fishes of the "Smalls" race (or some other race having a similar vertebral frequency) may occur at Plymouth and even to the eastward of Plymouth as far as off the Sussex coast, and also that fishes of the "Channel" race (or another race having a similar vertebral frequency) are to be found off Exmouth and Plymouth and in the western regions VIIf and g. The inevitable conclusion from this is either that there is an extensive overlap in the range of distribution for the two races named, or that races other than the "Smalls" and the "Channel" are represented in the samples. The same difficulty arises if we accept the findings of le Gall (17), who some years ago distinguished between "Hareng type Atlantique, variété côtière" inhabiting the Channel proper, and "Hareng type Atlantique, variété du large " which were confined to deeper water and included the fish trawled at the Smalls and elsewhere in region VIIg.

But all the samples taken within the area of investigation are not of classes 5 and 3 alone. There are the samples of classes 1, 2 and 4 to be considered, and each region presents difficulties on this account. In regions VIIf and g, in Mount's Bay and at Plymouth, samples of classes 1 and 2 occur for which the vertebral frequency graph is quite unlike that of either class 5 or class 3 . Schnakenbeck has remarked on this $(30$, p. 516) and definitely excluded them from his two main races. Perhaps the greatest difficulty arises, however, when we come to consider the samples of class 4 , for which the vertebral frequency graph is of a form intermediate between those of classes 5 and 3. How are they to be interpreted ? This question is of especial import in the Plymouth area where 37 out of the total of 50 samples belong to this class. Why in this area where the shoals are unquestionably assembled for spawning should there be such a dominance of samples which differ in vertebral distribution from the type-distributions characterising the "Channel" race and the "Smalls" race? If, as Schnakenbeck suggests (30, p. 518), the great majority of the Plymouth herrings in the winter months belong to the same race (i.e. the "Channel " race) as the herrings of the eastern Channel one would have expected close agreement in number of vertebræ between the majority of the Plymouth samples and those from off the Sussex coast. Instead, it is found that the Sussex samples are almost entirely of class 3 , those of class 4 being absent, whereas at Plymouth class 4 samples outnumber those of class 3 by nearly 4 to 1 . It will be necessary in a moment to note the degree to which the "number of vertebræ " for a sample of class 4 differs from that of a sample of class 3, but even if the difference were but slight, the fact remains that there is a difference, and that the Plymouth samples as a rule contain fewer fishes with 55 vertebræ and more than 56 than is shown by the Sussex samples. If, then, the "Channel" race actually exists, which are the NEW SERIES.-VOL. XIX. No. 1. AUGUST, 1933. 
purer samples of the race, those from Plymouth or those from Sussex? Furthermore, how does the difference between samples of class 3 and class 4 arise?

As a step in the study of these questions let us determine the extent of the difference between the vertebral distribution shown by the Plymouth samples and those from Sussex, restricting attention to those of classes 3 and 4 . In the following Table XI samples are tabulated according to the percentage of fishes with 55 and 56 vertebræ respectively, in the form of a correlation table. The data relating to Sussex samples of class 3 are shown in the bolder clarendon type, those relating to Plymouth samples of class 3 are in italics, while the plain numbers refer to Plymouth samples of class 4 :-

\section{TABLE XI}

Number of Samples according to Percentages of Fishes with

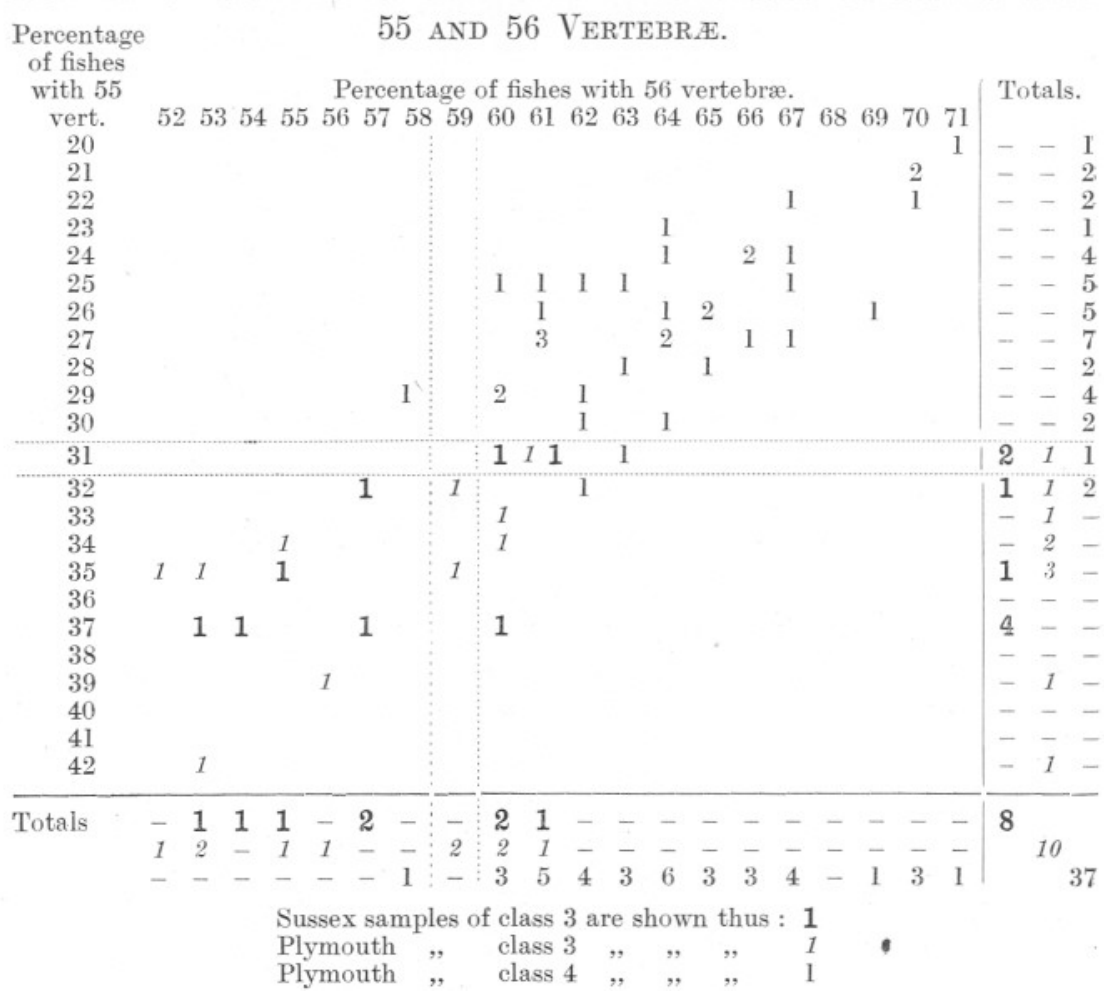

It is seen from Table XI above that there is very little overlap between the Sussex samples of class 3 and the Plymouth samples of class 4 . Whereas the former show from $31-37 \%$ of fishes with 55 vertebræ and 
from $53-61 \%$ of those with 56 vertebræ, the latter show from $20-32 \%$ with 55 vertebræ and from $58-71 \%$ with 56 vertebræ. On the other hand, the class 3 samples from the Sussex coast agree very well with the class 3 samples from Plymouth.

There appear three possible explanations of this definite difference between the Plymouth and the Sussex samples :-

1. The Sussex samples are "pure" samples of the Channel race, whereas the Plymouth samples are mixtures of Channel and some other race.

2. The Plymouth samples are "pure" samples of the Channel race, whereas the Sussex samples are mixtures of races.

3. Both the Sussex and the Plymouth samples are mixtures of races.

There is evidence from other sources that, at the eastern end of the English Channel and entrance to the North Sea, samples of herrings vary considerably in vertebral character. Thus, le Gall (19, p. 254), dealing with the French fisheries, has had to divide his area into three regions, in each of which the herrings differ in number of vertebræ. In the region southward of the Somme, from that river to Cap Antifer, the herrings are assigned to " Groupe II," for which the number of vertebræ as determined by samples during the past few years is as follows :-

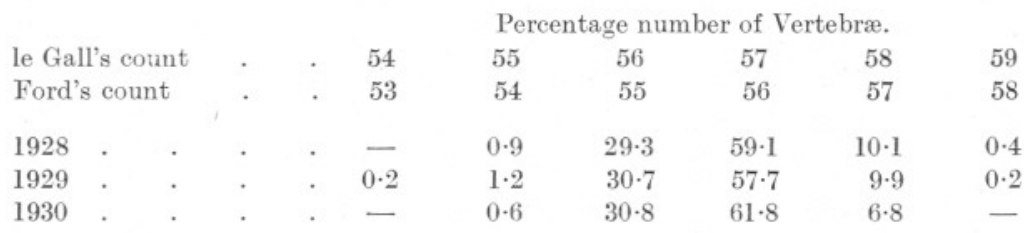

Fishes of this "Groupe" are regarded as of a distinct "Channel" race, and it is seen that they conform very closely with Schnakenbeck's figures. It is also worth noting that the number of vertebræ on average tends to be on the low side as compared with the Plymouth samples of class 4 . Thus, the percentage of fishes with 56 vertebræ does not amount to $62 \%$, while the percentage with 55 vertebræ is not less than $29 \%$ (cf. Table X on p. 349).

Le Gall's second region is to the northward of the Somme between Cap Griz-Nez and the Somme, and the herrings are here referred to "Groupe I" : -

\begin{tabular}{|c|c|c|c|c|c|c|c|c|c|}
\hline \multirow{3}{*}{\multicolumn{2}{|c|}{$\begin{array}{l}\text { le Gall's count } \\
\text { Ford's count }\end{array}$}} & & & \multicolumn{6}{|c|}{ Percentage number of Vertebræ. } \\
\hline & & . & & 54 & 55 & 56 & 57 & 58 & 59 \\
\hline & & . & . & 53 & 54 & 55 & 56 & 57 & 58 \\
\hline 1928 & . & - & • & $1 \cdot 2$ & $3 \cdot 4$ & $44 \cdot 4$ & $45 \cdot 8$ & $5 \cdot 2$ & - \\
\hline 1929 & . & - & . & 一 & $2 \cdot 5$ & $35 \cdot 3$ & $55 \cdot 3$ & $6 \cdot 7$ & - \\
\hline 1930 & . & . & . & $0 \cdot 2$ & $1 \cdot 8$ & $35 \cdot 0$ & $56 \cdot 4$ & $6 \cdot 3$ & $0 \cdot 2$ \\
\hline
\end{tabular}


There is in this group more variation. It is seen that by comparison with the classification used in this paper, the 1928 analysis is of our class 2 , while those of 1929 and 1930 are of our class 3. Le Gall regards these as varying admixtures of two races, namely, his " Channel " type and "The Southern North Sea" type, the latter being mainly confined to the Southern North Sea, and characterised by an average number of vertebræ lower than that of the Channel type. His "Southern North Sea " type would show a frequency graph of the "truncated" type somewhat similar to those given by our classes 1 and 2 .

Le Gall's third group is the " Groupe Dyck-Sandettié," coming from the region Dyck-Sandettié-Ruytingen, and captured mainly in the trawl :-

\begin{tabular}{|c|c|c|c|c|c|c|c|c|c|c|}
\hline \multicolumn{11}{|c|}{ Percentage number of Vertebræ. } \\
\hline le Gall & 's count & . & . & 54 & 55 & 56 & 57 & 58 & 59 & \\
\hline Ford's & count & . & . & 53 & 54 & 55 & 56 & 57 & 58 & \\
\hline 1928 & . & . & . & $0 \cdot 8$ & $2 \cdot 5$ & $35 \cdot 3$ & $55 \cdot 3$ & $6 \cdot 7$ & $0 \cdot 2$ & \\
\hline 1929 & . & . & $\theta$ & $0 \cdot 3$ & $4 \cdot 5$ & $43 \cdot 7$ & $47 \cdot 3$ & $3 \cdot 8$ & $0 \cdot 1$ & $\begin{array}{l}\text { (also } 0.3 \text { less than } \\
53 \text { vert.) }\end{array}$ \\
\hline $1930^{*}$ & . & . & . & & & $39 \cdot 0 *$ & $52 \cdot 7 *$ & 6.5 & & \\
\hline
\end{tabular}

Here again, le Gall is led to regard these samples as mixtures of the two races named above, for it is impossible to assign them to either one or the other.

Le Gall has thus been able to interpret his results only by extending the range of the "Channel " race into the North Sea and introducing North Sea fish into the Channel. Tesch (35), in his investigations of young herrings in the southern sea entrances of Holland, and of adult herrings from the southern North Sea and the eastern part of the English Channel, also finds it necessary to assume considerable overlap in range between races of the North Sea and those of the Channel, even going so far as to suggest "kinship" between the young fish from the Ooster-Schelde and the Plymouth fishes.

Gilson (21), too, investigating the Belgian fishery for "spent" herrings between Ostende and Cap Gris-Nez, obtained counts of vertebræ which cannot be reconciled with a single race.

Leaving the eastern end of the Channel to return to the Plymouth samples, it cannot be said that the samples show any greater tendency to conform to type than those in the localities just dealt with. Some of the Plymouth samples could be referred to the "Channel" race, but there remain others which could not, either because the number of vertebræ is too low (class 2 samples) or because it is too high (samples of class 5 and a proportion of those of class 4). If races exist, then the Plymouth samples provide evidence of race mixture.

* There is an obvious error in the setting up of this table in the original, but the figures given appear to be the correct interpretation. 
Summarising the conclusions reached in this section, it appears that :-

1. Not all the samples from VIIg conform with the "Smalls" race.

2. Not all the samples from the Plymouth district conform to the "Channel" race.

3. Not all the samples at the eastern end of the Channel conform to the "Channel" race.

4. The number of vertebræ tends to be higher in samples from the Atlantic end of the Channel than in those from the eastern end, although there is an appreciable range of variation in the sampleaverages in each region investigated.

\section{Samples from Plymouth and District.}

Seeing that the Plymouth district is an important spawning ground, it is just here that one would most expect to obtain pure race samples. Furthermore, since spawning fishes may occur at Plymouth from the end of September until late in the spring, there would seem to be reasonable time for more than one race to spawn without overlap. But as the Plymouth samples were not specifically collected as part of a "race" enquiry, it is, perhaps, hardly surprising that they do not prove very satisfactory for this latter purpose. The majority of them are heterogeneous in the sense that they are composed of fishes which vary in the condition of the gonads, and none of them are sufficiently large to warrant the breaking-up into components.

There is some evidence, however, for believing that in the year 1925, fishes with a comparatively low number of vertebræ spawned within Plymouth Sound from the end of September until the beginning of November. On the nights of September 30 th, October 8 th, and November 1st, stop-nets set in the Sound beneath the Laboratory took catches which included a number of spawning fish, and on October 25th a drift-net catch in Cawsand Bay also included spawners. Further evidence of this local spawning was afforded by the capture of "spent" fish in the Tamar estuary on November 20th. The low number of vertebræ characterising these samples is exemplified by the following results :-

Date. Locality.

(1925).

Oetober 25 th

November 1st

November 20 th

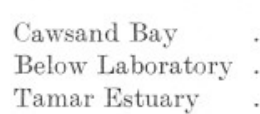

Percentage number of Fishes with number of Vertebræ as follows : $\begin{array}{lllll}54 & 55 & 56 & 57 & 58\end{array}$ $\begin{array}{lllll}3 & 42 & 53 & 3 & -\end{array}$ $1 \quad 45 \quad 50 \quad 5 \quad-$

$\begin{array}{lllll}- & 39 & 56 & 4 & -\end{array}$

In the following year, 1926, a sample from the Sound below the Laboratory on October 21st, and samples from Cawsand Bay on October 18th and 25 th included a few spawners, although not so many as in the previous 
year. Of these three, the Cawsand Bay sample of October 18th showed a low number of vertebræ, but the remaining two did not :-

Date.

(1926).

October 18th

October 2lst

October 25 th
Locality.

\begin{tabular}{lrr} 
Cawsand Bay & & 53 \\
Below Laboratory & $\cdot$ & - \\
Cawsand Bay & $\cdot$ & - \\
\hline
\end{tabular}

Percentage number of Fishes with number of Vertebræ as follows :

$\begin{array}{rrrrr}54 & 55 & 56 & 57 & 58 \\ - & 46 & 47 & 7 & - \\ - & 28 & 63 & 8 & 1 \\ 3 & 23 & 64 & 10 & \end{array}$

Samples taken on the open drifting grounds outside Plymouth Sound during October and November in 1925 and 1926, were composed entirely of " full " fishes at maturity-stages IV and V. Only one of these samples, namely that taken in East Bay on November 18th, 1925, showed a vertebral distribution comparable with the low values given by the samples from the Sound and Cawsand Bay. The remainder included a higher proportion of fishes with 56 vertebræ :-

Date. Locality.

November 4th, 1925

November 18th, 1925

November 3rd, 1926

November 4th, 1926

November 15th, 1926

November 23rd, 1926

Whitsand Bay
East Bay .
Off Looe :
Off Rame Head .
Rame-Eddystone
Rame-Eddystone

Percentage number of Fishes with number of Vertebræ as follows :

$\begin{array}{rrrrrr}53 & 54 & 55 & 56 & 57 & 58 \\ - & 1 & 24 & 67 & 8 & 1 \\ - & 2 & 35 & 59 & 5 & - \\ - & - & 28 & 65 & 7 & - \\ - & - & 27 & 64 & 9 & - \\ - & 2 & 27 & 61 & 10 & - \\ 1 & 1 & 29 & 62 & 7 & -\end{array}$

Putting these facts together, there may be some justification for suspecting that in October and November, fishes which are low in number of vertebræ spawn in the neighbourhood of the Sound. But, outside the Sound on the usual drifting grounds, shoals are present which are not yet ready to spawn and which have a higher number of vertebræ. The difference in vertebral character between these two kinds is shown graphically in Fig. 10, the "flat-topped " graphs applying to the early spawners.

In contrast with this, it has been found almost impossible to make a similar separation of samples taken during December, January and February, when the main fishery is in progress. Considerable spawning occurs all the time, but vertebral distribution appears to vary without relation to the stage of maturity. In Table XII, data are given for ten samples, selected because they each consist for the most part of fishes in the spawning condition, i.e. at maturity-stage VI :-

\section{TABLE XII}

Percentage number of Fishes

Sample.
1
2
3
4
5
6
7
8
9
10

with number of Vertebræ as follows :

$\begin{array}{ll}55 & 5 \\ 34 & 55 \\ 32 & 6 \\ 31 & 6 \\ 30 & 6 \\ 29 & 6 \\ 27 & 6 \\ 27 & 64 \\ 24 & 64 \\ 23 & 63 \\ 20 & 7\end{array}$

Arithmetic
Mean No. of
Vertebræ.
$55 \cdot 72$
$55 \cdot 70$
$55 \cdot 72$
$55 \cdot 77$
$55 \cdot 80$
$55 \cdot 79$
$55 \cdot 83$
$55 \cdot 82$
$55 \cdot 91$
$55 \cdot 86$


Comparison between samples shows :-

1. The percentage of fishes with 55 vertebræ varies between $34 \%$ and $20 \%$

$2 . \quad, \quad, \quad, \quad, \quad 56 \quad, \quad, \quad, \quad, \quad, \quad, \quad, \quad, \quad, \quad 71 \%$

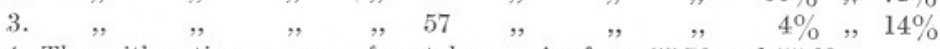

4. The arithmetic mean no. of vertebræ varies from $55 \cdot 70$ and $55 \cdot 91$.

The differences between the samples is thus quite considerable, and yet all of them consisted mainly of spawning fishes. That is to say, it is hardly permissible to regard the samples as representative of one and the same race, unless the differences in vertebral composition are overlooked. Nor as an alternative, is it any easier to accept the vertebral differences as evidence of the presence of, say, two races, for this would mean that two races must be spawning together on the same grounds at the same time.

\section{Vertebral Variation among Spawning Fishes.}

In an endeavour to obtain fuller knowledge concerning the variation in the number of vertebræ among fishes spawning together, two larger samples of actually spawning fish were analysed during January, 1931. To obtain the first of these samples, the writer proceeded to Sidmouth in Devon, where the chances of obtaining spawners in the requisite quantity appeared to be most favourable. On January 6th, a drift-net catch of several thousands was landed, and as soon as possible after landing, a start was made in the process of going through the catch, fish by fish, gently squeezing the abdomen to determine whether or not ripe eggs could be expressed. All the fishes which had thus been proved to be females fully ripe for spawning were retained, and a total of 355 individuals

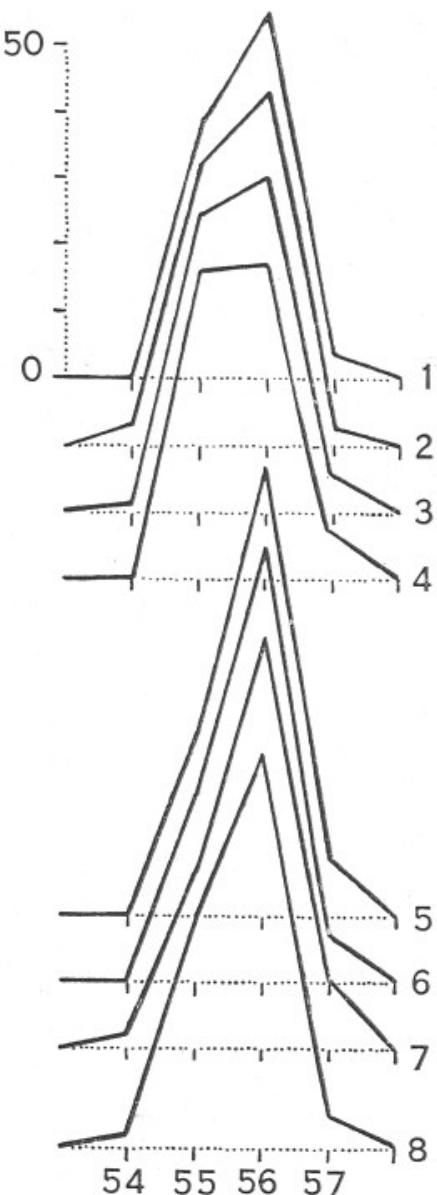

Fig. 10.

Percentage frequency graphs of number of vertebræ.

1. R. Tamar, November, 1925.

2. Cawsand Bay. October, 1925.

3. Sound. November, 1925.

4. Cawsand Bay. October, 1926.

5. Whitsand Bay. November, 1925.

6. Off Looe. November, 1925.

7. Rame-Eddystone. November,

8. Bigbury Bay. November, 1925. 
was collected before the catch must needs be packed for transport. It may be explained that the restriction of the sample to females only was largely a matter of convenience. It is well known that at maturation the eggs become translucent and the ovaries lose their firmness - eggs escape easily from the body in response to slight pressure, giving a sure indication of ripeness. In the case of the males, there is not that certainty in distinguishing ripe from unripe-or so it appears to the writer.

The sample having been forwarded to Plymouth, the length of each fish was determined, the age was read from the scales, and the number of vertebræ in the cleaned skeleton was counted. In reading the age from the scales, some disappointment was felt when it was found that by no means every fish could be referred with certainty to a definite yeargroup. Since it was undesirable to reject any part of the sample on this account, additional age-classes had to be created so that every fish would be included in the final summary of age.

The sample as a whole and in its age-components gave the following results :-

\section{TABLE XIII}

Number of Fishes in each of the following Vertebræ-Classes :

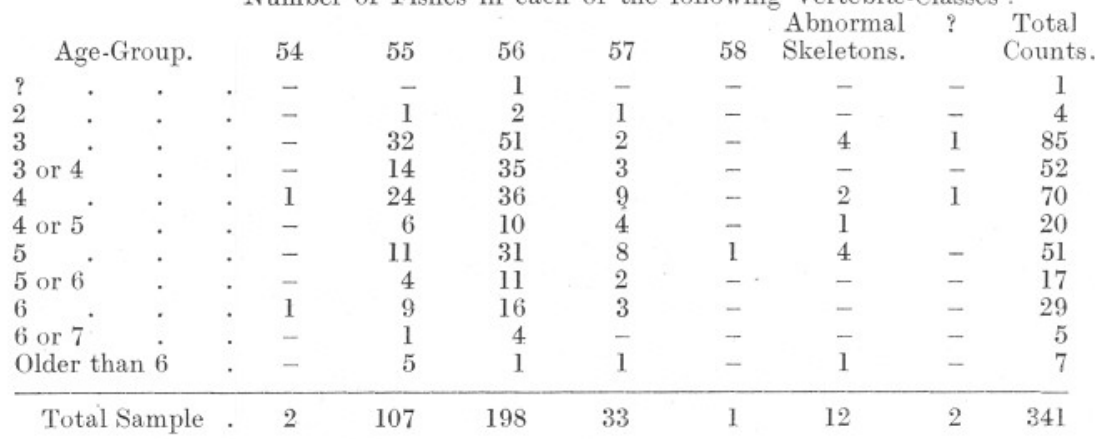

Although the numbers of fishes in the separate age-groups are not as large as could be wished, the following calculations of arithmetic means and errors serve their purpose in demonstrating that the vertebral distribution is subject to appreciable variation :-

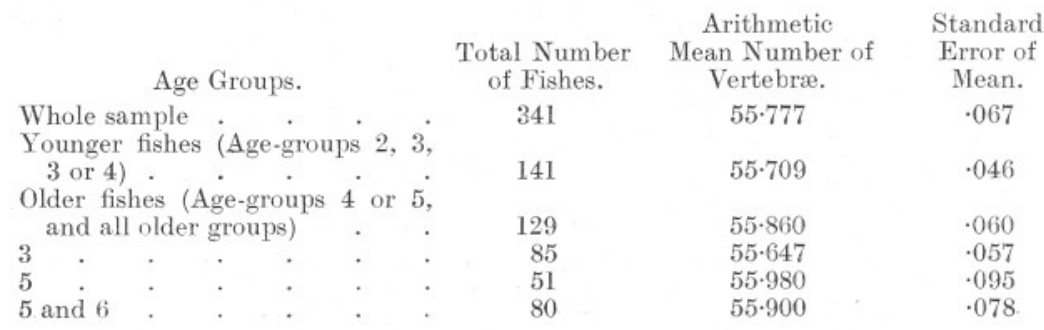


Whether or not these differences in average number of vertebræ may be considered significant is shown by the results of tests of independence. given in Table XIV :

\section{TABLE XIV}

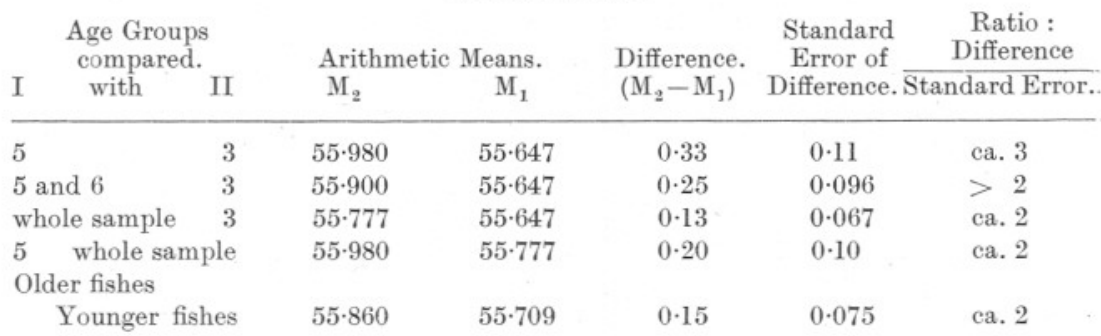

From these results one is at least justified in hesitating to regard the total samples as "homogeneous" in vertebral distribution. The fishes of age-group 3 appear not to agree with those of age-group 5, or with those of groups 5 and 6 taken together, and younger fishes do not agree with older ones. Recalling that every fish in this Sidmouth sample was a fully-mature female, ready to spawn if not actually doing so, it is difficult to escape the conclusion that the spawning population sampled was a mixed assembly of fishes which differed in vertebral distribution from age-group to age-group.

The second sample came from a total of about one thousand herrings caught by s.s. Salpa, using the otter trawl in Bigbury Bay on January 14th, 1931. With the assistance of four colleagues at the Plymouth Laboratory, a total of 623 fishes from this catch were subjected to an analysis of length, sexual condition, age and number of vertebræ. In all, 439 individuals were ripe (Stage VI), while the remaining 184 included "full " fishes at stage V, and "spents" at stage VII.

It was found that the male fish were generally shorter in length than the females :-

\begin{tabular}{|c|c|c|c|c|c|c|c|c|c|c|c|c|}
\hline & Stage of & & & & gth & lasse: & $(\mathrm{cm}$. & & & & \multirow{2}{*}{\multicolumn{2}{|c|}{$\begin{array}{l}\text { Mean Length } \\
\text { Male. Female. }\end{array}$}} \\
\hline ex. & Maturity. 21 & 22 & 23 & 24 & 25 & 26 & 27 & 28 & 29 & 30 & & \\
\hline 0 & VI & - & 2 & 3 & 13 & 74 & 103 & 64 & 17 & 2 & $27 \cdot 45$ & \\
\hline 7 & VI & - & - & 1 & 2 & 29 & 66 & 47 & 13 & & & $27 \cdot 79$ \\
\hline d & V & - & - & 1 & 5 & 28 & 33 & 17 & & 1 & $27 \cdot 42$ & \\
\hline 7 & V & - & - & - & 2 & 15 & 24 & 15 & 5 & 1 & & $27 \cdot 65$ \\
\hline & VII & - & - & 1 & 1 & - & 3 & 1 & - & - & $26 \cdot 07$ & \\
\hline & VII & - & - & - & 2 & 4 & 4 & 5 & 6 & 2 & & $28 \cdot 15$ \\
\hline
\end{tabular}

Finding that the difference in length between male and female persisted even when age was also taken into account, it was decided to treat the 
sexes separately in the investigation of their number of vertebræ, as in Table XV:-

\section{TABLE XV}

No. of Fishes in following Vertebræ Classes.

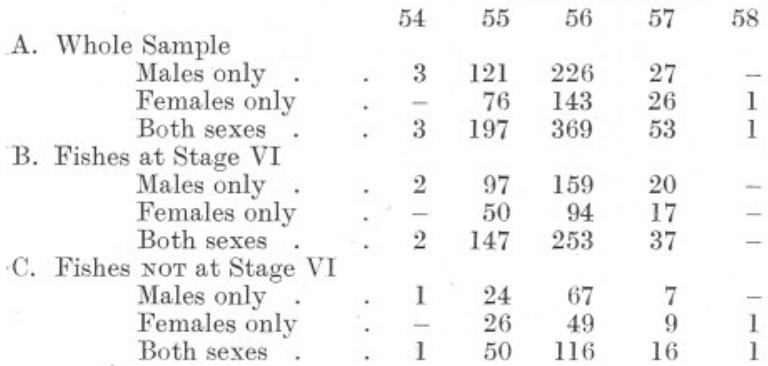

$\begin{array}{cc}\begin{array}{c}\text { Arithmetic } \\ \text { Mean No. } \\ \text { of Vertebræ. }\end{array} & \begin{array}{c}\text { Total } \\ \text { No. of }\end{array} \\ & \text { Fishes. } \\ & \\ 55 \cdot 735 & 377 \\ 55 \cdot 805 & 246 \\ 55 \cdot 762 & 623 \\ & \\ 55 \cdot 709 & 278 \\ 55 \cdot 795 & 161 \\ 55 \cdot 740 & 439 \\ & \\ 55 \cdot 808 & 99 \\ 55 \cdot 823 & 85 \\ 55 \cdot 815 & 184\end{array}$

It is clear from Table XV that the females were not only of a greater average length, but had a higher average number of vertebræ. The male fish at maturity stage VI gave interesting results. Of the total of 278 , no less than 142 were old fishes exceeding the age of 6 zones, 6 rings, and having the following number of vertebræ :-

\begin{tabular}{lcccccc} 
No. of Vertebræ &. & 54 & 55 & 56 & 57 & 58 \\
No. of Fishes &. & 1 & 56 & 77 & 8 & - \\
& \multicolumn{4}{c}{ Arithmetic Mean No. of vertebræ $=55 \cdot 648$} \\
Standard Error of Mean & \multicolumn{3}{c}{$=0.050$}
\end{tabular}

The male and female fish at maturity stage VI thus gave the following averages :-

Arithmetic mean No. of vertebræ.

"Old" Males
Other Males
Females .
All .

Statistical test shows that the difference of $0 \cdot 147$ vert. between the mean for the old males and that for the females can hardly be attributed to chance. This being so, not much significance can be attached to the actual value of the arithmetic mean number of vertebræ for all the fishes of stage VI taken together. Thus, as was the case with the Sidmouth sample, there is reason to doubt whether the spawning population sampled was really homogeneous in vertebral character.

It cannot be claimed that the results given by these two samples definitely prove that spawning populations may be mixed in vertebral character, but they certainly demonstrate that just as much care is needed when comparing samples which are homogenous in sexual condition as is demanded when samples are not homogeneous in that respect. It is 
seen that the arithmetic mean number of vertebræ for the total Sidmouth sample of spawners is almost the same as that for the spawners among the Plymouth sample. The samples were taken within a few miles of each other and at practically the same date. Everything thus appears to favour the view that fishes belonged to a single stock. But the analysis of the samples has shown that it is doubtful whether, under the circumstances, the means for the samples as a whole can be legitimately compared at all.

$$
\text { Herrings of the " } O \text { " Group. }
$$

The number of vertebræ of the offspring from a spawning stock is a matter of importance. Many counts of vertebræ in samples of late postlarval and metamorphosing herrings have been made at Plymouth, and large differences have been observed. Two facts have been recorded (Ford, 14, p. 748) concerning the number of vertebræ in samples taken from neighbouring estuaries during 1927 and 1928 from April until June :-

1. The number of vertebræ tended to be higher in later months.

2. Within the same day's sampling, the number of vertebræ changed with the length of the fishes.

The extent of the difference which may be shown between samples taken at different times is exemplified by the data for samples taken on May 26th, 1927, and April 5th, 1928 :-

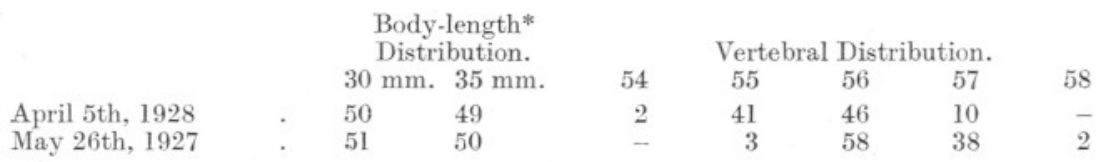

The very high number of fishes with 57 vertebræ in the sample of May 26th may occasion some surprise, as this does not usually much exceed $10 \%$ in samples of adults at Plymouth. The correspondingly low number with 55 vert. is also unusual. The data given, however, have been confirmed by the counting of a second sample. Perhaps a more typical case is provided by a comparison between the above sample of April 5th, 1928, and one taken on May 18th of the same year, and even here the difference is self-evident:- Body-length Distribution.

May 18 th, 1928

\section{$30 \mathrm{~mm}$. $35 \mathrm{~mm}$.}

Vertebral Distribution.

$\begin{array}{llcc}55 & 56 & 57 & 58\end{array}$

$41 \quad 46 \quad 10 \quad-$

The second feature, that of difference in vertebral distribution within one and the same sample, is exemplified by samples taken on May 27th

* The "body-length" is equivalent to the total length less the caudal fin. Defects in the caudal fin of many specimens necessitated the use of this alternative method of expressing length (vide Ford, 10, p. 307). 
and June 25th, 1928 (Ford, 14, p. 749). In the May sample, fishes less. than $35 \mathrm{~mm}$. in body-length had a higher average number of vertebræ than those exceeding $35 \mathrm{~mm}$., while in the June sample, fishes from 50 to $55 \mathrm{~mm}$. had a higher average than those from 60 to $65 \mathrm{~mm}$.

\section{The Sample and the Race.}

The various forms of investigation described above agree in showing that in an attempt to use the "number of vertebræ " given by random samples as a clue to the racial composition of the populations sampled, there is the persistent difficulty of apparent race-mixture. This leads us to enquire into the validity of the basic proposition that the number of vertebræ as given by a sample can be accepted as an estimate of a race character. For convenience in writing, we will refer to the sample estimate as the "sample-number" and to the race character as the "race-number."

Having determined a large number of sample-numbers, an investigator may decide to place some of them in a group apart from the rest because they agree. He may make a special note of the absolute value of the number of vertebræ which is characteristic of the members of the group he has created and decide to establish this as a "type" to which future samples of the same vertebral composition may be referred. But this "type" is nothing more than a quite arbitrary standard, and the " constancy "with which the members of the group conform to type is solely the result of the deliberate exclusion of samples which differ from standard. The mere sorting-out of sample-numbers into types according to a criterion of vertebral distribution of itself proves nothing beyond the fact that a certain number of the samples are alike in their number of vertebræ, but differ from others in this respect. It is simply and solely a technique for the assessment of the amount of variation in vertebral distribution.

Alternatively, the investigator may first segregate his samples according to some character other than the number of vertebra, only to find that in one of the resulting groups all the samples also agree in vertebral distribution. In this instance the agreement between the "sample-numbers" is not merely the result of a deliberate choice of sample according to an arbitrary standard of vertebral distribution, but a sequel to a selection of samples according to some other criterion. It shows, moreover, that there is a correlation between the character used for the sorting of the samples and the number of vertebræ.

The fundamental difference between the above two alternatives is selfevident, but it needs to be remembered in the present discussion of "sample-numbers" and "race-numbers." Were it proven that the 
principle of "race-numbers" is valid, the first alternative would be a legitimate method for conducting racial analyses, but unless and until that principle is established, the results of such analyses remain entirely speculative. By the adoption of the second of these alternatives and paying due regard to the sexual condition of the fishes in the samples he utilises, Schnakenbeck has accumulated a wealth of valuable information which he offers as substantial evidence for the " race-number." Certainly, he has shown that sexual condition and "sample-number" are interdependent, but it is a matter of opinion as to whether or not he has proved either that the number of vertebræ is strictly inherited, or that spawning populations are homogeneous in vertebral composition-and these two premises are the fundamental elements of the theory of unalterable "race-numbers."

Without more knowledge than is at present available concerning the inheritance of the number of vertebræ, there must remain some uncertainty as to the real significance of observed difference between " samplenumbers." There is at least the possibility that some part of this difference is phenotypic - a possibility which may increase the difficulty of using "sample-numbers" as " race-numbers " in seeking to establish genotypes. This explains the present writer's hesitation in accepting the system of herring races postulated by Schnakenbeck, or, at the present time, to proceed further with a racial analysis of the Plymouth samples than has been indicated in the foregoing pages. It may well be that Schnakenbeck has in broad outline already mapped out the different races as they actually exist, and that his technique is basically sound, but he has given no proof.

Until this proof is forthcoming, it is held that "sample-numbers" should be treated merely as characters of the temporary populations from which the samples are drawn and not as "race-numbers." They can be used in conjunction with data on age and growth as clues to the movements of the shoals which result in the formation of those temporary populations, and persistent work of this kind ought ultimately to reveal the different entities represented in the populations. The Scottish investigations on the autumn-spawning and spring-spawning herrings in Scottish waters provide an excellent example of the application of this method.

Concerning the Plymouth spawning population, there remains no doubt that it is very complex. Whatever character is considered, it is found that the Plymouth fishes have something in common with those taken in regions to the eastward and westward. Just as some of the Plymouth fishes are indistinguishable in growth from those caught at the eastern end of the Channel, while others resemble those taken in the Atlantic fisheries, so also there is a relation between the "sample-number" of 
vertebræ in the three districts. On the whole, also, growth in length in western regions tends towards a higher limiting value than that in eastern regions ; similarly, the number of vertebræ tends to rise from east to west. Many of the Plymouth herrings exhibit " mixed " growth, suggesting that in the seasons between successive spawnings they have visited different feeding grounds; so, too, the number of vertebræ varies from sample to sample, as if to confirm the belief that the Plymouth spawning population is drawn from a number of different sources. The explanation which seems best to fit these results is that the shoals which arrive in succession to spawn off Plymouth come both from the deeper parts of the English Channel proper and from the more open waters at the Atlantic entrance. After spawning, they return to off-shore waters, although not necessarily to the same grounds from which they came. Accepting the view that the Plymouth spawners spend the whole of their lives within a fairly definable and comparatively limited geographical area, and that the number of spawning places is also limited, it might be permitted to speak somewhat loosely of a "south-western" herring which differed, say, from a Norwegian herring. Nevertheless, there will be marked individual variation among "south-western" fishes in both growth and number of vertebræ, since the size of annual increments of growth depends upon the feeding grounds visited when fishes are a given age and size, while the number of vertebræ, although in a measure dependent upon the parental number, may yet be affected by the environmental conditions under which fishes are born and develop.

\section{The Rearing of Young Herrings.}

Great advance in our knowledge of genotypes in herrings might be expected if it were possible to rear herrings of known parentage under controlled conditions. In practice it is a comparatively simple process to express eggs from a ripe female and to fertilise them with the milt from a ripe male. The eggs thus "set" will develop quite normally in sea-water and give a plentiful yield of active and apparently strong larvæ. No special care is needed to secure this result other than that usually taken in the experimental rearing of marine animals. Whenever opportunity has permitted at Plymouth, eggs have been fertilised and incubated until larvæ have appeared. Eggs have been incubated in plunger-jars; in running water and still; in the light and in the dark; in water of different temperature and salinity. Unfortunately, however, no larvæ have ever been reared much beyond the stage at which the yolk-sac is absorbed, and it has become increasingly evident that the problem of rearing cannot be treated as an incidental to other enquiries if success is to be achieved. It must be undertaken as a major research. As an aid 
in this it was thought that Plymouth could assist by acting as a distribution centre for fertilised eggs and supply workers in laboratories elsewhere, where facilities for rearing are available.* Thanks to the co-operation of Mr. Storrow at Cullercoats ; Professor Orton of Liverpool University, and Mr. Smith of Port Erin ; Mr. Elmhirst of Millport; and Mr. Weller of the Municipal Aquarium at Brighton, trial consignments were sent to the above places and reports made on subsequent incubation. Ripe eggs were expressed from females into glass jars (breffits) partly filled with water, the jars being moved about meanwhile so as to distribute the eggs as evenly as possible in a single layer over the inside of the jar. The eggs were then fertilised by pouring into each jar a small quantity of a suspension of sperm in sea-water. After fertilisation had been effected, the water was changed. Two breffits containing eggs and securely capped with glass covers and muslin, were packed in a hamper and despatched. by rail to each of the four Laboratories mentioned. The hampers for Brighton, Cullercoats and Millport left by passenger train, and that for Port Erin went first to Liverpool by rail and was then transferred to the steamer for Douglas in the Isle of Man. Upon arrival at their destination, the eggs were housed according to the facilities available. Excellent hatchings were reported.

\section{The Number of Myomeres in Larval Herrings.}

Being unable to rear larval herrings of known parentage until the number of vertebræ could be counted, an attempt was made to determine how the number of myomeres varied, but with equally disappointing results. It is well known that an error of one or two in the counting of myomeres is unlikely to lead to a mistaken identification of a herring as distinct from a sprat or a pilchard. But no such latitude in precision of count is permissible when studying myomeral variation within a herring brood - the counts must be reliable statistics - and in practice there was no assurance on this important point. It is thought, however, that with opportunity for closer investigation, interesting results might be forthcoming.

\section{Incubation of Herring Eggs in Waters of different Salinities.}

Despite the failures referred to above, it has been shown (Ford, 13) that fertile eggs of the same parentage can be made to yield larvæ which differ in specific gravity as the result of incubation in waters of different

* There is, of course, nothing very new in this. As early as 1879, Dunn (4) forwarded some thirty or forty thousand eggs to the Brighton Aquarium in connection with a proposal to " enrich Australian waters with the English Herring," and he states that whereas full ninety days was required for the journey with the transported eggs still unhatched, it was found possible to "repress life " for only forty days. In later years, ova fertilised at Plymouth were the material for trial transportation to New Zealand, and were successfully taken as far as Cape Town. 
salinities. This opens up the question as to what anatomical variation, if any, might be expected to reveal itself in the fishes at a later stage of life, in consequence of this difference in environment during embryonic development. At present, nothing further can be added to the original report.

\section{The Metamorphosis of the Herring.}

Leaving the larva and turning to the stage in the life of a herring when it becomes transformed into a silvery and scaled adolescent, there is considerable variation to be explained. The marked changes in form during metamorphosis can be regarded as the consequences of differential growth in length (Ford, 14) and it is suggested that any circumstances which will affect the relative proportions of the different parts of the larval body, or which will influence the rate at which these different parts grow, must induce a difference in the form of the adolescent. It has been shown that at Plymouth the length at which metamorphosis occurs is by no means constant, and that early larvæ at an arbitrary stage of metamorphosis are larger and have a lower number of vertebræ than those at the same stage of transition in later months. To what extent these changes are genotypic or phenotypic remains to be determined.

\section{The Adult Fish.}

After the adolescent, there is the adult fish. Whether it has grown much or little; whether it has matured early or late; whether it agrees with or differs from a second fish in its number of vertebræ: there remains the ever-present difficulty regarding the interpretation of differences between individual herrings.

\section{Technique.}

It remains to speak of the technique by which the investigator seeks to recognise genotypes in the herring. Stated simply; he has to devise means for distinguishing between fishes which differ in factorial constitution. The manner in which he essays to solve the problem is immaterial, provided that his method is reliable. The "number of vertebræ " is a character much used in this connection, but it appears that there is still much to learn about this character. In a communication to the Journal $d u$ Conseil, * now in the press, the present writer has discussed the "number of vertebræ " as the sum of a series of bony elements which differ one from the other. Two individuals may have the same total number of vertebræ, but yet be different in the structure of the vertebral column. Reference must also be made to an important paper by Wollaston (39), recently published, in which the statistical treatment of sample data on the number of vertebræ is most critically examined.

* Journal du Conseil, Vol. VIII, No. 2, 1933. 


\section{FORECASTING THE YIELD OF THE FISHERY.}

It would be of practical advantage to the fishing industry if, at some time in advance of the opening of a new season's fishing, fishing prospects could be announced with regard to the following :-

(a) The date when profitable fishing might be expected to begin.

(b) The expected quality of the catches.

(c) The estimated yield of the fishery.

If events during the fishing season were repeated year after year with unbroken regularity, knowledge during any one season would be quite sufficient to indicate what would happen in the next. We know, however, that no such uniformity actually occurs. Even so, if it could be shown that the variation from season to season followed some rule, it might yet be possible to discover that rule from the study of past data, and hence to predict what is likely to occur in the future.

Is there any "law and order" governing the whole or some part of the fluctuations in fishing yield which can be discovered from the study of past data on the Plymouth fishery? Is there any certainty that future events will continue to follow the same course? Until positive answers can be given to these questions, any forecasting is pure speculation, and therefore without scientific value.

It can be regarded as certain that fishing results are dependent upon the weather, but in the present state of meteorological science, we cannot hope to receive much advance information regarding weather conditions during a forthcoming season. Hence, every form of fishery forecast which can be issued at the present time must of necessity include an important reservation dealing with the weather. Nevertheless, the official weather forecasts which are broadcast daily are themselves in the nature of fishery predictions. Thus, a gale warning is not solely an indication that an interruption of fishing is imminent, but also a portent of heavy catches when fishing is resumed after the enforced suspension. Alternatively, the prediction of a spell of calm weather may be interpreted as an indication of lighter catches. It is certain that a detailed study of the relation between weather and fishing yield will form an important part of future work on fishery prediction.

But however favourable the weather may be for fishing, the size and number of catches made are dependent upon the fish stocks. There is reasonable assurance that some fish, at any rate, will be found on the grounds as early as October, and that not until at least the end of January will it be possible to say that none can be caught in drift-nets. Moreover, during the intervening four months the condition of the fish will vary from 
individuals with half-filled roes and milts to fish which have spawned. But beyond these two general statements, it is almost impossible to be sure of anything except that the quantity and quality of fish caught varies from season to season, day to day, and from boat to boat, in a bewildering fashion.

It is believed that the fish come in successive shoals, partly from the English Channel proper and partly from the neighbouring Atlantic waters. After spawning, the fish will return once more to the deep. Year after year this inshore migration for spawning, and the return journey to the offshore feeding grounds, is repeated. An observer at Plymouth, therefore, by studying samples of fish taken during the winter fishery, can obtain a working idea of the changes which occur from one season to the next. He sees how the stock alters in character by the gradual replacement of older fish by younger; how that fishes born in a given year outnumber those born in other years; and he learns to distinguish between fishes which have come from different feeding grounds. From these detailed studies, conducted over a number of years, he finds that he can formulate an empirical cycle of events which will, to a useful degree, account for the observed changes in the fishable stock. Let us examine some of the results obtained in this way.

On p. 325 data were given on the age of fishes caught during the seasons 1924-25 to 1931-32, and it was there shown (1) that fishes born in certain years were much more important to the fishery than those born in others ; and (2) that fishes of any given year-class are of the greatest importance to the fishery in their fifth winter of life. Now these are observations which, strictly speaking, refer only to the period in which they were noted. That is to say, there is no certain proof that they will apply at some future date. On the other hand, there is no real necessity to assume that they will not. Accordingly, there can be no objection to the experiment of attempting to forecast the age-composition of catches during a future season on the basis of past observations. In the year 1929, an experiment of this kind was made, utilising data taken during the four seasons 1924-25 to 1927-28. (vide Ford, 11, p. 14.) It was predicted that the rich year-class 1923 would begin to decline in 1928-29 and that in its stead the very successful 1925 year-class would predominate in the catches of 1929-30. Furthermore, dates were given when year-classes 1922 to 1925 would cease to be important elements in the catches, and the opinion was expressed that by 1932-33 practically the whole of the stock represented in the catches of 1927-28 would be replaced by new stock. Concerning these experimental predictions it is now possible to say from actual experience that they were substantially correct. Since this first attempt it has been the custom at the end of each season to form an opinion as to the probable age-composition of the catches in the 
following year, and it may be said that there has been no fundamental discrepancy between forecast and fact.

It may not appear of great practical utility to be able successfully to forecast the age-composition of catches, nor is there any value in so doing, if the work is to stop at this point. But if it is remembered that as a fish gets older it increases in size, then it will be realised that a forecast of age-composition is also a forecast of "quality" of catch. For example, if catches during an impending season are expected to include a high proportion of old fish it means that big fish will outnumber small. Conversely, the prediction of a high percentage of young fish in future catches is only another way of saying that the average size of the fish will be small. But at Plymouth this is merely a generalised truth, for it is at present very difficult, if not impossible, to convert predictions of age-composition into precise predictions of size-quality, because fishes of the same age-group vary considerably in size. Of course, a high average age usually means a high average size, but an individual length is no criterion of age any more than an individual age is a criterion of length (cf. p. 326). Size will depend upon the feeding grounds which the fish have frequented in past years, so that the average size of the fishes taken during any season at Plymouth will depend upon the regions from which the shoals have come. And in the present state of knowledge there is little justification for assuming that each year sees an unaltered proportion of migrants from the Channel proper and from the Atlantic regions. If in some years there is a greater proportion of migrants from the Atlantic feeding grounds the average size for any given year-class is likely to be larger than in the years when the Channel migrants are in greater evidence. The winter of $1932-33$ provides a case in point. From the observations made during the preceding season it was anticipated that the catches of 1932-33 would include a high proportion of old fishes, since there had been no important replenishment of stock by younger year-classes in recent years. At the same time it was felt that unless the brood of the winter of 1929-30 had proved very successful in its survival the outlook for the fisheries of the immediate future was very disquieting. Now if these anticipations were to become realised facts the catches of 1932-33 should have shown an appreciable percentage of fishes of the larger sizes, as well as a fair quota of small individuals - the former being the old fishes remaining from previous stock and the latter the new arrivals of the young 1929-30 brood. Fishes of medium size, representing fishes from 4 to 6 years of age, should be few in comparison. These results were actually obtained during the fishery, but in a manner which was not, and could not have been foretold. Old fishes certainly predominated in the catches of 1932-33, so much so that samples taken from catches in several instances consisted of from $50 \%$ to $80 \%$ of individuals over the 
age of 6 years, whereas the average percentage for fishes over 6 years during the previous eight seasons was only $25 \%$. With so large a percentage of old fish it was quite according to expectation that the average size of the fishes in the catches should also be large, but it came as a surprise to see how large they really were. Individuals of $28 \mathrm{~cm}$. to $30 \mathrm{~cm}$. in length outnumbered others, while those from $25 \mathrm{~cm}$. to $27 \mathrm{~cm}$. were less in evidence than in perhaps any year since 1924-25. The explanation which most satisfactorily accounts for this fact is that shoals coming from the Atlantic regions were more numerous than in recent years.

Young fishes of the 1929-30 season made their appearance in a very marked manner during the months of September, October and November, 1932. During that period catches were landed at Plymouth and at a number of places off Cornwall which included anything from $30 \%$ to $60 \%$ of the 3 -year-old fishes of this year-class. The frequency and the characters of these fishes were altogether unusual, at least in the Plymouth area. They were of large average size in comparison with fishes of the same age usually caught at Plymouth, being about $25 \mathrm{~cm}$. long on average. But more noticeable still, they had a much higher average number of vertebræ than is usual in the district. Fishes having 57 vertebræ actually outnumbered those with 55 vertebræ, and the average number of vertebræ exceeded 56.0 in four out of the five samples taken from Plymouth landings. Such high vertebræ averages are not ordinarily obtained in Plymouth waters and can only be matched by averages in the Atlantic region VIIg. (vide p. 349). Samples from Mevagissey and Port Isaac, taken during the same period, showed very similar characters, and it seems most natural to conclude that these and the Plymouth fish were of like origin.

From these observations it would appear that the fishable stock on the Plymouth grounds during the 1932-33 season had come more from westerly sources than had been the case for a number of years. But this change was not predictable because there was no available evidence upon which to judge. Hence, although a knowledge of the age-composition of catches in previous years proved sufficient to prepare a forecast of the age-composition in 1932-33 there was no means of expressing more than a generalised opinion on the probable size-quality of the catches. In other words, the prediction of a high percentage of old fish implied that the average size would tend to be high, but it was impossible to state that the fishes would be mostly $28 \mathrm{~cm}$. to $30 \mathrm{~cm}$. in length, because it could not be foreseen that the shoals would be predominately westerly in character.

For the same reason there is at present a limitation to the accuracy with which forecasts of the quantity of fish can be given. As will be indicated below, extremely useful general indications as to the quantity of fish to be expected can be extracted from analyses of past records, but 
these are all dependent upon the underlying assumption of unaltered conditions between present and future. Four times out of five, or perhaps nine times out of ten, that assumption may be sufficiently near to the truth, but at the fifth or the tenth time it may fail. For example, a marked alteration in the migration of herrings such as is thought to have occurred during 1932-33 might well upset any prediction of quantity which did not take into account the possible effects of the migratory change. As to the causes which might induce these migratory changes, it has been suggested that the cyclic activity of Atlantic waters is one of the most important. Thus Storrow $(34$, p. 20$)$ says: "In the study of fluctuations of the herring fishery we are confronted with the problem of associating changes in fisheries with changes in waters, and these with changes in other phenomena such as the association of pressure distribution and winds." French investigators (vide le Gall, 20) have gone so far as to associate the fluctuation of the herring fisheries in the English Channel with rhythmic movement of Atlantic water over the Continental plateau, and to predict the success or failure of the fishery in consequence of this rhythm. Many will think, however, that our knowledge of the factors which govern the movements of herring shoals has not yet reached that stage when it can be used in the practical forecasting of fishing yield. But the fact remains that such knowledge will have to be sought after, despite the complexity of the problems awaiting solution.

But even if the significance of these unknown factors governing the movement of shoals is admitted, there is much to be learned from past results of actual fishing. In Table IV, on p. 315, the average weight per landing by steamers at Plymouth during each of the seasons 1924-25 to 1931-32 was given. Using these figures as the best available estimate of density of catch, and placing them alongside the corresponding agecomposition of the catch, we have the following material for study :-

\begin{tabular}{ccccccccccc} 
& \multicolumn{1}{c}{ Season. } & & \\
& $1924-$ & $1925-$ & $1926-$ & $1927-$ & $1928-$ & $1929-1930-$ & $1931-$ \\
Average weight per steamer- & 25 & 26 & 27 & 28 & 29 & 30 & 31 & 32 \\
landing (cwt.) & $\mathbf{4 0 \cdot 0}$ & $23 \cdot 1$ & $16 \cdot 6$ & $\mathbf{4 6 \cdot 3}$ & $27 \cdot 5$ & $39 \cdot 1$ & $32 \cdot 7$ & $17 \cdot 6$ \\
\hline
\end{tabular}

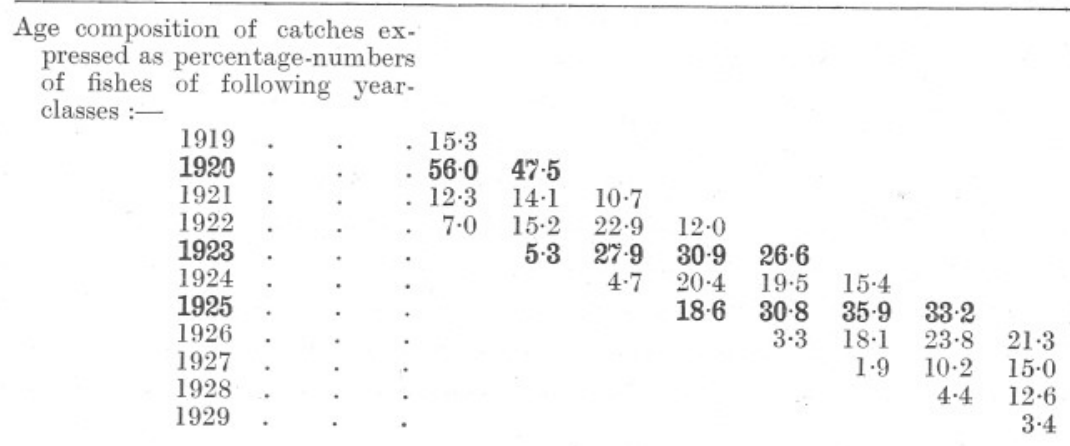


It will be seen from the above table that there is a relationship between the density of steamer-landing and the percentage-number of fishes in the three year-classes 1920, 1923 and 1925. The steamer-landing was heaviest in the three seasons 1924-25, 1927-28 and 1929-30, and in these same seasons the most important part of the catch consisted of fishes of 1920 , 1923 and 1925 year-classes, respectively, when those fishes were at the age of 5 years. In 1926-27 and 1931-32, the steamer-landing was very low, and it was in just those seasons that fishes of the above-mentioned year-classes were comparatively weakly represented. Thus, in 1926-27, the year-class 1920 had reached the age of 7 , so that the time had passed when it might be expected to make a heavy contribution to catches. Moreover, the 1923 year-class was only aged 4 , and therefore not yet yielding its full quota, while year-class 1925 was not due to appear in the catches until the following year. In 1931-32, all three classes had passed their zenith-it is probable that those of 1920 and 1923 were little more than nominally represented in the catches, if at all, while that of 1925 had reached its maximum two seasons previously. The data further show that the fishery from 1924-25 onwards has depended far more upon year-classes 1920, 1923 and 1925 than upon any others.

Putting these observations together, there seems good reason for thinking that the yield of the Plymouth fishery (as represented by the average weight per steamer-landing) fluctuates in accordance with the strength of a limited number of highly-successful year-broods, occurring only at intervals. The yield will reach a maximum when one of these rich broods is in its fifth winter. It follows from this that the moment an observer can learn of the arrival of a new and successful brood, he is in the position to forecast when fishing is likely to benefit from that event. Thus, when in the season 1927-28 the present writer (Ford, 11, p. 16) noted that the percentage of 3-zoned 3-ringed fishes of the year-class 1925 was unusually high, he could have gone on to predict that the fishery in 1929-30 would be good. And the prediction would have been realised, although made two years in advance.

The converse case must also be noted, for if during successive seasons no evidence is forthcoming that an important new brood is about to take the place of those passing out of the fishery, then it must be concluded that the fishery will suffer in consequence. In this connection it is of interest to consider the progress of the Plymouth fishery during the past four seasons (1929-30 to 1932-33). In 1929-30, when fishes of the rich yearclass 1925 at the age of 5 years made up $35.9 \%$ of the catch, the average steamer-landing was $39 \cdot 1$ cwt. During the following season of 1930-31, fishes of the same year-class, now 6 years old, were again dominant, but the average weight per steamer-landing fell to $32 \cdot 7 \mathrm{cwt}$. In 1931-32 the steamer yield was lower than it had been since 1926-27, while the catches 
consisted of no less than $47 \cdot 7 \%$ of fishes older than 6 years. These results plainly show that fishes of year-classes 1926, 1927, 1928 and 1929 were not present on the Plymouth grounds in anything approaching the density with which those of year-class 1925 had been. There are two ways of explaining these results. Either the broods of the winters 1925-26 to 1928-29 were poor in survival-rate as compared with that of 1924-25, or the four former broods did not visit Plymouth to the same extent as did the latter brood, but went elsewhere to spawn. Of the two explanations, the first appears the more likely since there is independent evidence that the dominance of the year-classes 1920, 1923 and 1925 was widespread (vide Storrow, 33 and 34).

The position at the end of the 1931-32 season at Plymouth, therefore, appeared anything but favourable for the fishery of 1932-33. What remained of the previously fished stock was old, while there was little to be expected from the oncoming younger broods. The only possible prediction which could be made was that the fish of the 1932-33 seasons would consist of a greater proportion than ever of old fish, and that the average yield would be low. As has already been shown, the proportion of old fish did prove to be exceptionally high, but it has to be noted that the average weight per steamer-landing was considerably heavier than might have been expected. Yet it must be said that this discrepancy between forecast and fact was more apparent than real because, unfortunately, the average of 34.2 cwt. per steamer-landing does not convey a fair estimate of the season's fishing. On p. 318 it was shown that fishing was only really productive during two periods, the first from December 7 th to December 18th, and the second from January 4th to 6th. Admittedly, during the 12 days of the first period and the 3 days of the second, the steamer-landings were very good, averaging $53 \mathrm{cwt}$. per landing (and this good result has been shown to have been dependent upon good fishing weather), but there were 36 other days during the season when the steamers were far less successful, and for which the average is only $20 \mathrm{cwt}$. as compared with the 9 -year seasonal average of $30 \cdot 8 \mathrm{cwt}$. The results of the motor fishery tell a similar story, for whereas there were 12 days on which the average weight per landing was equal to or greater than the seasonal average of $20 \cdot 2$ cwt., there were 27 days when the daily average was much below this figure. For the 12 days the average weight per landing was 36.5 cwt., but for the 27 days it was only 11.6 cwt., and there were an additional 17 days when no landings at all were made. Thus, when some two-thirds of a working season gives decidedly poor results, too much significance ought not to be attached to a seasonal average like the weight per steamer-landing which, in effect, spreads the heavy landing of a few days over a long period of poor yields. The result, as in the present instance, is apt to be misleading. 
From these observations it may be concluded that although the average weight per steamer-landing fluctuates from season to season in accordance with the changing age-character of the fishable stock, its limitation as a precise estimate of fishing yield creates some difficulty in forecasting future results. It will therefore be necessary for prediction purposes to find some better criterion of the density of fishing.

Now it is a self-evident fact that forecasts of quality and quantity which are determined in the manner just described are concerned only with the expected remains of previously-fished stock. They have nothing to do with that entirely fresh stock which enters the fishery for the first time in any one year. At Plymouth there is at present no means of anticipating the strength of the 3-year-old stock in an impending season, but this is of little practical consequence because the proportion of 3-year-old fishes in the catches is relatively unimportant. Elsewhere, however, where the catches always include a high proportion of 3-year-old stock (off the Sussex coast, for example), it would be necessary to discover some means of determining the relative richness of an oncoming year-class before it had reached its third year as well as to obtain an indication of the expected yield from previously-fished year-classes.

There remains to be considered the question of the time at which fishing in any season may be expected to begin. This matter of early and late seasons was given some attention in an earlier paper (Ford, 11) when it was suggested that the temperature of the sea may provide a clue. It was found that at temperatures above $13^{\circ} \mathrm{C}$. fishing tended to be poor, but that it improved as the temperature fell towards $11^{\circ} \mathrm{C}$. and became good as soon as the temperature was less than $11^{\circ} \mathrm{C}$. The "normal" date at which $11^{\circ} \mathrm{C}$. is reached is about December 19th. An individual season would thus be early or late in starting according as the temperature of $11^{\circ} \mathrm{C}$. is attained before or after the "normal " date. It has not been possible to examine this question in further detail, but it is worth noting that on December 6th, 1932, the temperature over the Bigbury Bay area of the fishing grounds was round about $11^{\circ} \mathrm{C}$. and on the next day, December 7 th, the steamers made the first big landing of the season. This suggests that the matter may be worthy of more critical and detailed investigation.

Having reviewed the present possibilities and limitations connected with the general question of predicting catches, it is convenient to consider available data in somewhat greater detail. The average agecomposition of catches during the eight seasons from 1924-25 to 1931-32 was given in Table VI on p. 325, and at the foot of that table the following means for the 8-year period were stated :-

$\begin{array}{lcccc}\text { Percentage Numbers of Fish at following Age: } \\ 3 & 4 & 5 & 6 & \text { Older than } 6 \\ 6 \cdot 1 & 18 \cdot 4 & 27 \cdot 3 & 22 \cdot 7 & 25 \cdot 3\end{array}$


The figures are seen to increase from the 3rd to the 5th year, but to begin to decline in the 6th. Assuming that the decline is continuous from the 6 th year onwards at a fixed rate of about $54 \%$ annually, the percentages at ages 7,8 and onwards may be estimated as follows, making the total percentage of fishes older than 6 amount to $25 \cdot 4$ instead of $25 \cdot 3$ :-

\begin{tabular}{ccccr}
\multicolumn{2}{c}{ Percentage Numbers of Fish at following } & Age : \\
7 & 8 & 9 & 10 & 11 \\
$12 \cdot 3$ & $6 \cdot 6$ & $3 \cdot 9$ & $1 \cdot 9$ & $1 \cdot 0$
\end{tabular}

The above may be regarded as representing the " normal " life of a yearclass in the fishery, and suggests that this life commences with a minor contribution at the age of 3 years, growing to a maximum at 5 years, and dwindling to a merely nominal representation from the age of 8 years onwards.

This hypothetical " life-table" is not only useful in giving an estimate of the length of time and the extent to which the fishery may be expected to profit or suffer by the presence of a " normal " year-class, but also in showing the manner in which oncoming year-classes must increase their quotas in order to make good the losses sustained by the passing out of the older classes. It is seen that of the nine year-classes which contribute to the catch of any one season, only those at the ages of 3 and 4 will increase their contributions during the next season, whereas the seven classes at the ages of 5 to 11 will contribute less than hitherto. Hence, if in actual experience a numerically weak year-class enters the fishery, its weakness will be almost immediately reflected in the density of the catch, while the effect upon the catch of two weak year-classes in succession will be very apparent. Conversely, the arrival of a rich year-class will lead to an early rise in the catch.

\section{TABLE XVI.}

\begin{tabular}{|c|c|c|c|c|c|c|}
\hline \multicolumn{2}{|l|}{ Season. } & \multicolumn{5}{|c|}{$\begin{array}{c}\text { Percentage by Weight contributed by Year-classes } \\
\text { at the following Age : }\end{array}$} \\
\hline Dec.-Jan. & & 3 & 4 & 5 & 6 & Older than \\
\hline $1924-25$ & . & $5 \cdot 6$ & $11 \cdot 7$ & $55 \cdot 8$ & $15 \cdot 7$ & $11 \cdot 3$ \\
\hline $1925-26$ & . & $3 \cdot 9$ & $13 \cdot 4$ & $13 \cdot 4$ & $49 \cdot 1$ & $20 \cdot 2$ \\
\hline $1926-27$ & . & $4 \cdot 2$ & $24 \cdot 2$ & $21 \cdot 8$ & $11 \cdot 3$ & $38 \cdot 5$ \\
\hline $1927-28$ & . & $14 \cdot 9$ & $18 \cdot 6$ & $32 \cdot 0$ & $12 \cdot 9$ & $21 \cdot 6$ \\
\hline $1928-29$ & . & $2 \cdot 6$ & $27 \cdot 6$ & $19 \cdot 4$ & $27 \cdot 7$ & $22 \cdot 7$ \\
\hline $1929-30$ & . & $1 \cdot 5$ & $16 \cdot 0$ & $34 \cdot 7$ & $15 \cdot 9$ & $31 \cdot 8$ \\
\hline $1930-31$ & . & $3 \cdot 5$ & $9 \cdot 4$ & $22 \cdot 8$ & $33 \cdot 3$ & $31 \cdot 0$ \\
\hline $1931-32$ & . & $2 \cdot 8$ & $10 \cdot 6$ & $13 \cdot 8$ & $21 \cdot 7$ & $51 \cdot 1$ \\
\hline Average & . & $4 \cdot 9$ & $16 \cdot 4$ & $26 \cdot 7$ & $23 \cdot 4$ & 28.5 \\
\hline
\end{tabular}

When one comes to consider the density of actual catches in relation to their composition by age, there is the difficulty that the catches are expressed in terms of either volume (crans) or weight (cwt.), whereas 
the age composition is given in numbers. Since no actual data are available as to the weight of fishes at different ages (and such would be difficult to obtain in practice), the alternative has been adopted of obtaining a working idea of the age-composition of catches, by weight, by assuming that weight is proportional to the cube of the length and then calculating the weight of fishes at different ages from the corresponding lengths. Table XVI, on page 377, is thus an expression by weight of the numerical age-composition given in Table VI, on p. 325 .

Dividing up the average weight per steamer-landing according to the above percentages, season by season, we obtain the following :-

\begin{tabular}{|c|c|c|c|c|c|c|}
\hline Season. & $\begin{array}{l}\text { Average weight } \\
\text { per } \\
\text { steamer-landing. } \\
\text { (cwt.) }\end{array}$ & 3 & $\begin{array}{c}\text { Weight o } \\
4\end{array}$ & $\begin{array}{l}\text { at fo } \\
\quad 5\end{array}$ & $\begin{array}{c}\text { g Age } \\
6\end{array}$ & $\begin{array}{l}\text { (cwt.). } \\
\text { Older than } 6\end{array}$ \\
\hline $1924-25$ & $40 \cdot 0$ & $2 \cdot 2$ & $4 \cdot 7$ & $22 \cdot 3$ & $6 \cdot 3$ & $4 \cdot 5$ \\
\hline $1925-26$ & $23 \cdot 1$ & 0.9 & $3 \cdot 1$ & $3 \cdot 1$ & $11 \cdot 3$ & $4 \cdot 7$ \\
\hline $1926-27$ & $16 \cdot 6$ & $0 \cdot 7$ & $4 \cdot 0$ & $3 \cdot 6$ & $1 \cdot 9$ & $6 \cdot 4$ \\
\hline $1927-28$ & $46 \cdot 3$ & $6 \cdot 9$ & $8 \cdot 6$ & $14 \cdot 8$ & $6 \cdot 0$ & $10 \cdot 0$ \\
\hline $1928-29$ & $27 \cdot 5$ & $0 \cdot 7$ & $7 \cdot 6$ & $5 \cdot 3$ & $7 \cdot 6$ & $6 \cdot 2$ \\
\hline $1929-30$ & $39 \cdot 1$ & $0 \cdot 6$ & $6 \cdot 3$ & $13 \cdot 6$ & $6 \cdot 2$ & $12 \cdot 4$ \\
\hline $1930-31$ & $32 \cdot 7$ & $1 \cdot 1$ & $3 \cdot 1$ & $7 \cdot 5$ & $10 \cdot 9$ & $10 \cdot 1$ \\
\hline $1931-32$ & $17 \cdot 6$ & $0 \cdot 5$ & $1 \cdot 9$ & $2 \cdot 4$ & $3 \cdot 8$ & $9 \cdot 0$ \\
\hline Average & $30 \cdot 4$ & $1 \cdot 7$ & $4 \cdot 9$ & $9 \cdot 1$ & $6 \cdot 75$ & $7 \cdot 9$ \\
\hline$\%$ & $99 \cdot 9$ & $5 \cdot 6$ & $16 \cdot 1$ & $30 \cdot 0$ & $22 \cdot 2$ & $26 \cdot 0$ \\
\hline
\end{tabular}

With the seasonal catch thus split up into age-components, it becomes possible to estimate how much the fishery depended upon the three yearclasses 1920, 1923 and 1925 :-

\begin{tabular}{|c|c|c|c|c|c|c|}
\hline \multirow[b]{2}{*}{ Season. } & $\begin{array}{l}\text { Average weight } \\
\text { per }\end{array}$ & \multicolumn{5}{|c|}{ Weight of Fish of following Year-classes. } \\
\hline & $\begin{array}{l}\text { steamer-landing. } \\
\text { (cwt.) }\end{array}$ & 1920 & 1923 & 1925 & Total. & Percentage. \\
\hline $1924-25$ & $40 \cdot 0$ & $22 \cdot 3$ & - & - & $22 \cdot 3$ & 56 \\
\hline $1925-26$ & $23 \cdot 1$ & $11 \cdot 3$ & $0 \cdot 9$ & - & $12 \cdot 2$ & 53 \\
\hline $1926-27$ & $16 \cdot 6$ & $3 \cdot 5^{*}$ & $4 \cdot 0$ & - & $7 \cdot 5$ & 45 \\
\hline $1927-28$ & $46 \cdot 3$ & $3 \cdot 0 *$ & $14 \cdot 8$ & $6 \cdot 9$ & $24 \cdot 7$ & 53 \\
\hline $1928-29$ & $27 \cdot 5$ & $1 \cdot 0^{*}$ & $7 \cdot 6$ & $7 \cdot 6$ & $16 \cdot 2$ & 59 \\
\hline $1929-30$ & $39 \cdot 1$ & $\cdot 5 *$ & $6 \cdot 7 *$ & $13 \cdot 6$ & $20 \cdot 8$ & 53 \\
\hline $1930-31$ & $32 \cdot 7$ & $\cdot 3 *$ & $4 \cdot 0^{*}$ & $10 \cdot 9$ & $16 \cdot 2$ & 50 \\
\hline $1931-32$ & $17 \cdot 6$ & $\cdot 2^{*}$ & $2 \cdot 0^{*}$ & $4 \cdot 9 *$ & $7 \cdot 1$ & 40 \\
\hline
\end{tabular}

It is thus estimated that in each season from 1924-25 to 1931-32, the year-classes 1920, 1923 and 1925 accounted for approximately one-half of the catch. A measure of the superior yield of these three classes is provided by comparing their quotas at the age of 5 and 6 when they were

* These values are estimates on the assumption that rate of decrease each year after the 6 th is about $54 \%$ annually. 
making their fullest contribution to the fishery, with the corresponding quotas of other year-classes :-

Weight contributed to
steamer-landing dur-

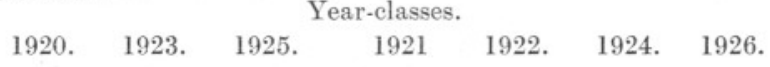
ing 5 th and 6 th years

It is seen that the quotas contributed by the year-classes 1920, 1923 and 1925 were individually much in excess of those given by the classes 1921, 1922, 1924 and 1926. The largest quota, that of 1920, was over six times as great as the smallest, viz. that of 1921, while the quotas of 1923 and 1925 were each from four to five times the heavier.

With this measure of the inequality of the contributions to the catch made by successive year-classes, and the knowledge of the extent to which the density of the catch is dependent upon the contributions made by a limited number of year-classes, the chances of being able to predict the trend of future fishing would seem to be favourable, provided that it is possible to learn in advance which year-classes are the ones of promise. Looking over the results of the past eight seasons, one must conclude that a good year-class hardly makes itself evident in catches before it is in its fourth year, although the impending importance of yearclass 1925 became evident when that class was at the age of 3 . Nevertheless, this is one year's prior notice of an important influence upon the size of the catch. Earlier indication, however, may be forthcoming by the examination of catches taken during the months from September to November, when it is usual for local boats to land catches of younger fish. Certainly in the late autumn of 1932, fishes of year-class 1930 were particularly in evidence, and it is upon this class that one expects the fishery of the near future to depend in no small measure. Admittedly, they were not generally strong in the commercial catches of December, 1932 and January, 1933, although occasional catches were landed which included a good percentage of small fish, but if the year-class is to be as important as the October samples suggested, then the catches in 1933-34 should show an appreciable percentage of 4-year-old fish, while in 1934-35, this year-class, now in its fifth winter, should be a dominant element in the catches. Accordingly, the yield of the fishery should show a new and satisfactory maximum in 1934-35, subject, of course, to the reservations discussed above.

From these observations at Plymouth it has been concluded that the continuous study of the changes in the character and density of commercial landings provides clues to the size and quality of future landings, despite the fact that the results of a season's fishing so obviously depend to an appreciable degree on circumstances which cannot as yet be foreseen. The limitations of the average weight per steamer-landing as an estimate 
of the density of the fishable stock are large, but they do not mask the fact that fishing-yield fluctuates in accordance with the varying richness of successive year-broods. In practice it is possible to obtain advance information of the relative richness of broods and hence of the relative success of future fisheries. But there still remain possible influences which may militate against a forecast of yield based entirely on this evidence, chief among these being the factors which govern the migrations of herrings. These call for investigation.

\section{LITERATURE CITED.}

1. Cooper, L. H. N. Chemical Constituents of Biological Importance in the English Channel. Part III. Journ. Mar. Biol. Assoc., N.S., Vol. XIX, No. 1. 1933.

2. Cunningham, J. T. Fish and Fisheries. Lecture 13 delivered at the Cornwall County Fisheries Exhibition held at Truro, 1893.

3. Dunn, Matrhias. Some Habits of the Picked Dogs, Herrings, and Pilchards, on the Coasts of Devon and Cornwall. 54th Annual Report of the Royal Cornwall Polytechnic Society, Falmouth, 1886.

4. - The Migrations and other Habits of the Herring on the Coasts of Devon and Cornwall. Ibid., 62nd Annual Rept., 1894.

5. - Remarks in connection with the Laws, Capture, and Natural History of the Herring and Pilchard. Ibid., 55th Annual Rept., 1887.

6. Ford, E. The Number of Pyloric Cæca in the Herring. Journ. Mar. Biol. Assoc., N.S., Vol. XII, No. 2. 1920.

7. —— Herring Investigations at Plymouth. I. Ibid., Vol. XV, No. 1. 1928.

8. —— Herring Investigations at Plymouth. II. Ibid., Vol. XV, No. 1. 1928.

9. — Herring Investigations at Plymouth. III. Ibid., Vol. XV, No. 1. 1928.

10. - Herring Investigations at Plymouth. IV. Ibid., Vol. XV, No. 1. 1928.

11. — Herring Investigations at Plymouth. V. Ibid., Vol. XVI, No. 1. 1929.

12. — Herring Investigations at Plymouth. VI. Ibid., Vol. XVI, No. 1. 1929. 
13. Herring Investigations at Plymouth. VII. Ibid., Vol. XVI, No. 1. 1929.

14. - - Herring Investigations at Plymouth. VIII. Ibid., Vol. XVI, No. 3. 1930.

15. Ford, E., ANd Bull, H. O. Abnormal Vertebræ in Herrings. Journ. Mar. Biol. Assoc., N.S., Vol. XIV, No. 2. 1926.

16. Fraser, J. H. On the Size of Urosalpinx cinerea (Say) with some Observations on Weight-Length Relationship. Proc. Malacol. Soc., Vol. XIX, Part V. 1931.

17. Le Gall, J. Études diverses sur la question du Hareng. Office Scient. Tech. des Pêches Mar., Notes et Rapp., No. 48. 1926.

18. — Études sur le Hareng. Revue des Travaux de l'Office des Pêches Maritimes, Tome I, Fasc. 1. 1928.

19. — Statistiques biologiques et considérations sur la population harenguières de la Manche orientale et du Sud de la Mer du Nord. Revue des Travaux de l'Office des Pêches Maritimes, Tome IV, Fasc. 3. 1931.

20. - Quelques prévisions sur la prochaine saison de pêche du hareng en Manche orientale. La Pêche Maritime, No. 652. November 23rd, 1930.

21. Gilson, G. Recherches sur la biologie du hareng "Guai" et sur sa pêcherie entre Ostende et la cap Gris-Nez en 1930-31. Annales de l'Institut d'Études Maritimes d'Ostende, Mem. No. 1. 1931.

22. Graham, M. Some Problems in Herring Behaviour. Journal du Conseil, Vol. VI, No. 2, p. 252. 1931.

23. Hловт, J. Report on Herring Investigations until January 1910. Cons. Int. Expl. Mer., Publ. de Circ., No. 53. 1910.

24. Hodgson, W. C. Investigations into the Age, Length and Maturity of the Herring of the Southern North Sea. Part I. Min. Agric. Fish., Fish. Invest., Ser. II, Vol. VII, No. 8. 1924.

25. - Investigations into the Age, Length and Maturity of the Herring of the Southern North Sea. Part II. Ibid., Ser. II, Vol. VIII, No. 5. 1925.

26. - - Investigations into the Age, Length and Maturity of the Herring of the Southern North Sea. Part III. Ibid., Ser. II, Vol. XI, No. 7. 1929.

27. Lea, E. The Herring's Scale as a Certificate of Origin. Its Applicability to Race Investigations. Cons. Int. Expl. Mer., Rapp. et Proc.-Verb., Vol. LIII. 1929. 
28. Orton, J. H. An Account of the Researches on Races of Herrings carried out by the Marine Biological Association at Plymouth, 1914-15. Journ. Mar. Biol. Assoc., N.S., Vol. XI, No. 1. 1916.

29. Schnakenbeck, W. Zum Rassenproblem bei den Fischen. Journal du Conseil, Vol. VI, No. 1, p. 28. 1931.

30. — Zum Rassenproblem bei den Fischen. Zeitschr. f. wiss. Biol, Abt. A. Zeitschr. f. Morphol. u. Ökol. d. Tiere. 21 Band, $3 / 4 \mathrm{Heft}$, p. 409.1931.

31. Stevens, G. A. Rays and Skates of Devon and Cornwall. II. Journ. Mar. Biol. Assoc., N.S., Vol. XVIII, No. 1. 1932.

32. Stornow, B. Herring Investigations. Dove Mar. Lab. Rept., N.S., XII. 1923.

33. — - Herring Investigations. Ibid., N.S., XVI. 1927.

34. — Herring Investigations. Ibid., N.S., XX. 1931.

35. Tesch, J. J. Investigations on the Herring in the Southern North Sea. Cons. Int. Expl. Mer., Rapp. et Proc.-Verb., Vol. LIV. 1929.

36. Wallace, W. First Report on Young Herring in the Southern North Sea and English Channel. Part I. Min. Agric. Fish., Fish. Invest., Ser. II, Vol. VII, No. 4. 1924.

37. Watkin, E. E. Investigations on Cardigan Bay Herring. Part V. Rept. Mar. and Fresh Water Invest., Dept. Zool., Univ. Coll., Wales, Aberystwyth, Vol. II. 1927.

38. — The Drift Herring of the South East of Ireland and its Fishery. Cons. Int. Expl. Mer., Rapp. et Proc.-Verb., Vol. LXXXIV. 1933.

39. Wollaston, H. J. B. Some Modern Statistical Methods: their Application to the Solution of Herring Race Problems. Journal du Conseil, Vol. VIII, No. 1. 1933. 
TABLE XIX.

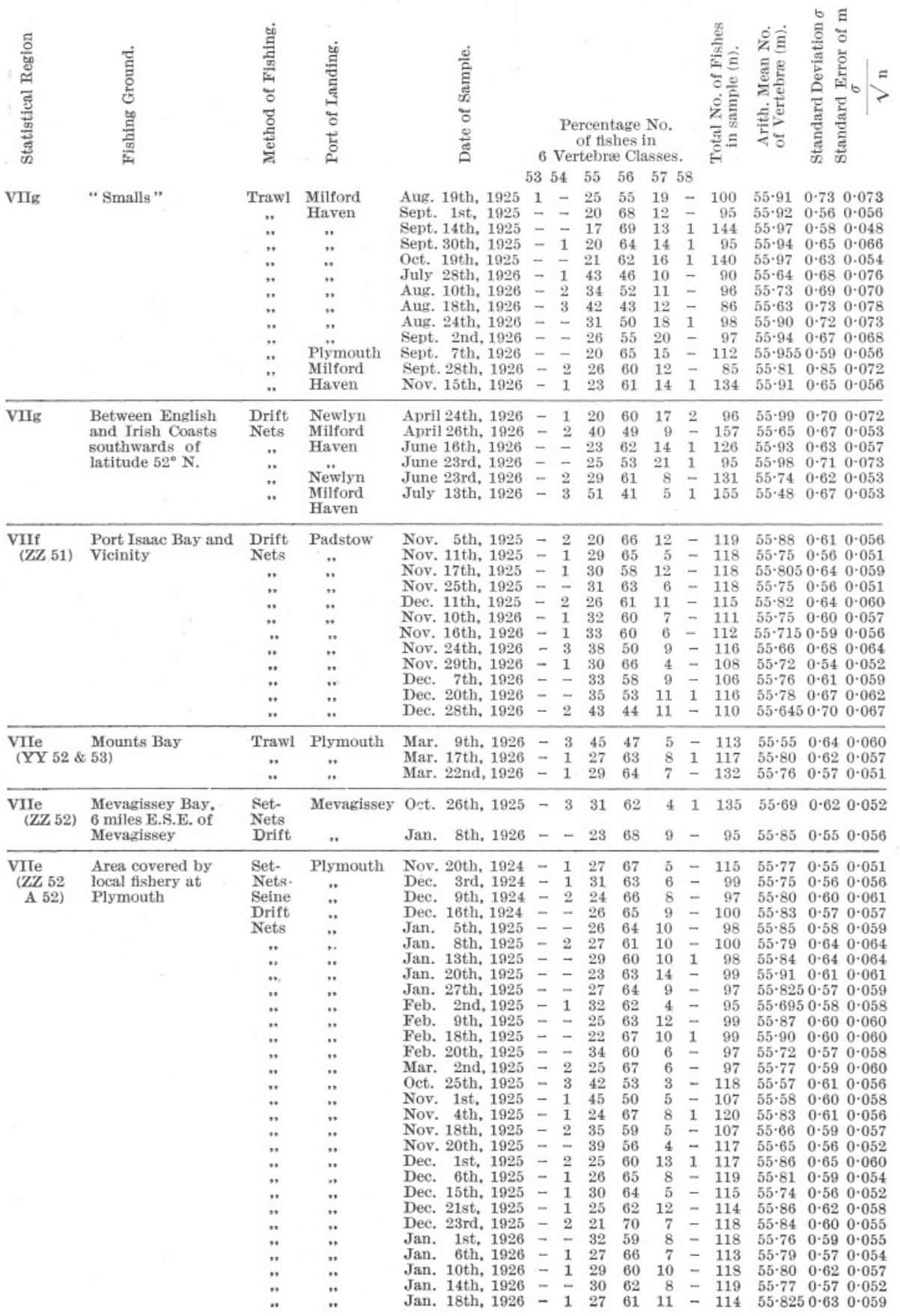


TABLE XIX-continued.

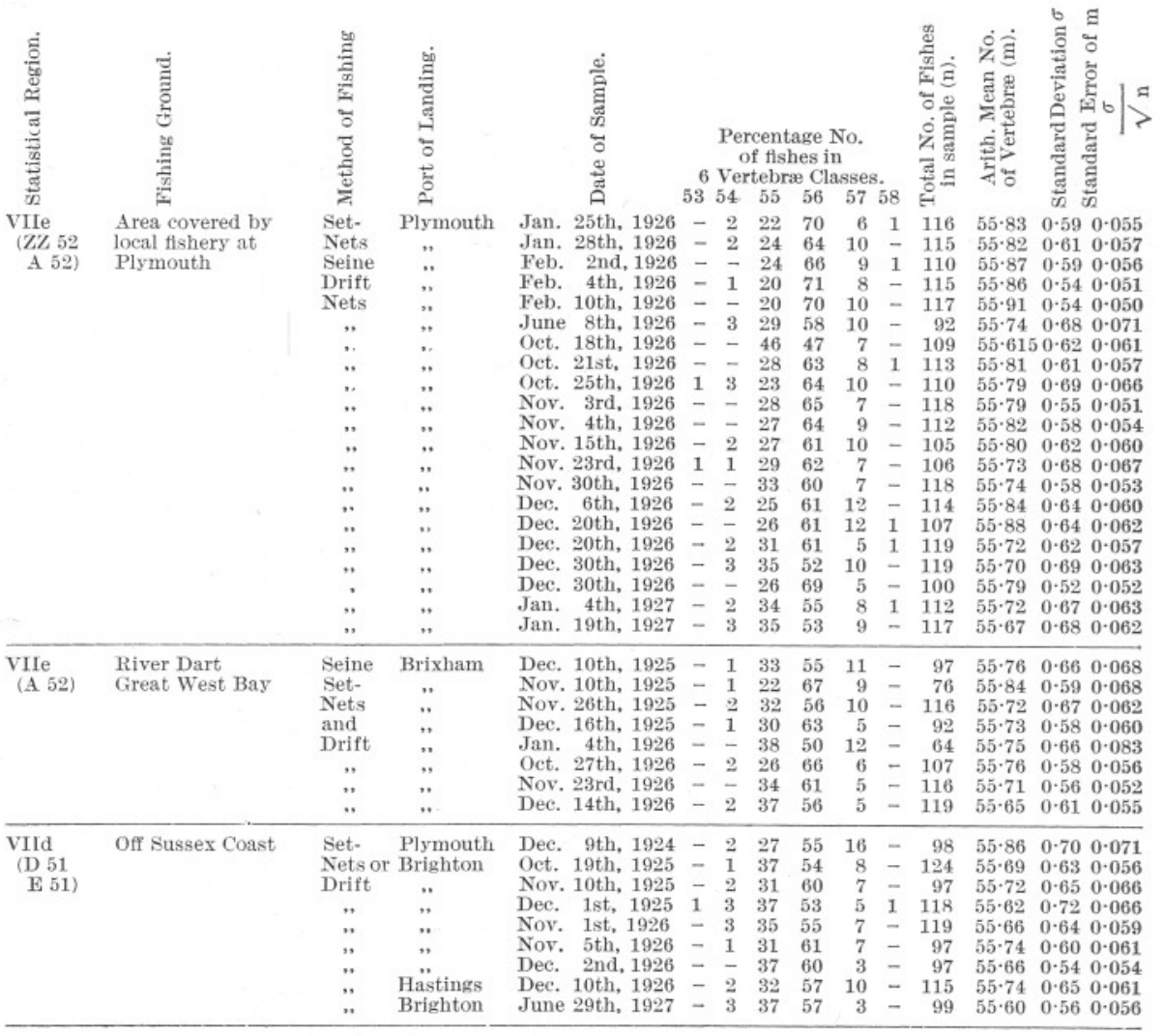

